PNL-6851

UC-11,41

50

\title{
40 CFR 265 Interim-Status Ground-Water Monitoring Plan for the 2101-M Pond
}

\author{
M. A. Chamness \\ S. P. Luttrell \\ S. Dudziak
}

March 1989

Prepared for the U.S. Department of Energy under Contract DE-AC06-76RLO 1830

Pacific Northwest Laboratory

Operated for the U.S. Department of Energy by Battelle Memorial Institute 


\title{
DISCLAIMER
}

This report was prepared as an account of work sponsored by an agency of the United States Government. Neither the United States Government nor any agency thereof, nor Battefle Memoriat Institute, nor any or their employees, makes any warranty, expressed or implied, or assumes any legal liability or responsibility for the accuracy, completeness, or usefulness of any information, apparatus, product, or process disclosed, or represents that its use would not infringe privately owned rights. Reference herein to any specific commercial product, process, or service by trade name, trademark, manufacturer, or otherwise does not necessarily constitute or imply its endorsement, recommendation, or favoring by the United States Government or any agency thereof, or Battelle Memorial Institute. The views and opinions of authors expressed herein do not necessarily state or reflect those of the United States Government or any agency thereof.

\author{
PACIFIC NORTHWEST LABORATORY \\ operated by \\ BATTELLE MEMORIAL INSTITUTE \\ for the \\ UNITED STATES DEPARTMENT OF ENERGY \\ under Contract DE-ACO6-76RLO 1830
}

\begin{tabular}{|c|c|}
\hline \multicolumn{2}{|c|}{ Printed in the United States of America } \\
\hline \multicolumn{2}{|c|}{ Available trom } \\
\hline \multicolumn{2}{|c|}{ National Technical Information Service } \\
\hline \multicolumn{2}{|c|}{ United States Department of Commerce } \\
\hline \multicolumn{2}{|c|}{ 528S Port Royal Road } \\
\hline \multicolumn{2}{|c|}{ Springfield, Virginia $2216 \uparrow$} \\
\hline \multicolumn{2}{|c|}{ NrIS Price Codes } \\
\hline \multicolumn{2}{|c|}{ Microfiche $A 01$} \\
\hline \multicolumn{2}{|c|}{ Printed Copy } \\
\hline & Price \\
\hline Pages & Codes \\
\hline $001-025$ & $\mathrm{~A} 02$ \\
\hline $026-050$ & $\mathrm{~A} 03$ \\
\hline $051-075$ & A64 \\
\hline $076-100$ & A0S \\
\hline $701-125$ & A06 \\
\hline $126-150$ & An7 \\
\hline $15 T-175$ & $\operatorname{Ax} x$ \\
\hline $176-200$ & $\mathrm{AOO}$ \\
\hline $201-225$ & A10 \\
\hline 226.250 & A11 \\
\hline $251-275$ & A12 \\
\hline $276-300$ & A 73 \\
\hline
\end{tabular}


40 CFR 265 INTERIM-STATUS GROUND-WATER MONITORING PLAN FOR THE 2101-M POND
M. A. Chamness
S. P. Luttrell
S. Dudziak

March 1989

Prepared for

the U.S. Department of Energy

under Contract DE-AC06-76RLO 1830

Pacific Northwest Laboratory

Richland, Washington 99352 



\section{PREFACE}

Although this document is being printed in 1989 , it was prepared in Aprit 1988. The procedures, preliminary interpretations, and schedules in this document reflect conditions in the first half of 1988 and are thus subject to changes as a result of ongoing technical audits and reviews. 


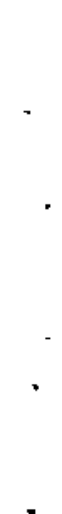




\section{SUMMARY}

This report outlines a ground-water monitoring plan for the 2101-M pond, located in the southwestern part of the 200-East Area on the Hanford Site in south-central Washington State. It has been determined that hazardous materials may have been discharged to the pond. Installation of an interimstatus ground-water monitoring system is required under the Resource Conservation and Recovery Act to determine if hazardous chemicals are moving out of the pond.

This plan describes the location of new wells for the monitoring system, how the wells are to be completed, the data to be collected, and how those data can be used to determine the source and extent of any ground-water contamination from the 2101-M pond. Four new wells are planned, one upgradient and three downgradient. 

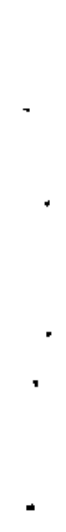


\section{CONTENTS}

PREFACE ...................................... i

SUMMARY . . . . . . . . . . . . . . . . . . . . . . . V

1.0 INTROOUCTION . . . . . . . . . . . . . . . . . . . . . . 1.1

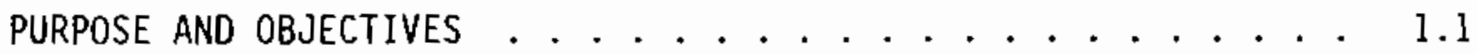

SCOPE ........................... . . . . . . . . . . . . .

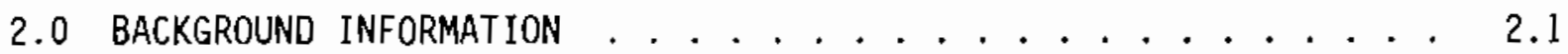

FACILITY DESCRIPTION . . . . . . . . . . . . . . . 2.1

Location and Physical Description . . . . . . . . . 2.1

History .................... 2.1

Current Waste Characteristics . . . . . . . . 2.5

GEOLOGY . . . . . . . . . . . . . . . . . . . 2.5

Regional Geologic Setting ............. 2.7

Geology of the Separations Areas . . . . . . . . . . 2.7

Stratigraphy Beneath the 2101-M Pond . . . . . . . . 2.12

HYDROGEOLOGY ....................... 2.15

Regional Setting................. 2. 2. 15

Ground-Water Hydrology of the Separations Areas . . . . . 2.16

Ground-Water Hydrology Beneath the 2101-M Pond . . . . . 2.18

HISTORICAL GROUND-WATER DATA . . . . . . . . . . . 2.25

Water Levels . . . . . . . . . . . . . . . . 2.25

Ground-Water Quality................. 2.26

3.0 PHASE I. INDICATOR EVALUATION GROUND-WATER MONITORING
PROGRAM. . . . . . . . . . . . . . . . . . . .

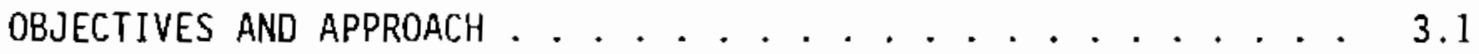

objectives..................... . . 3.1 


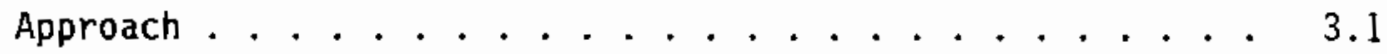

INDICATOR EVALUATION MONITORING PROGRAM . . . . . . . 3.4

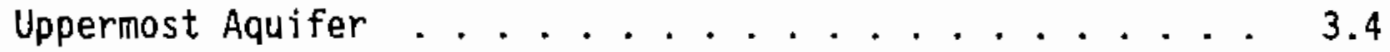

Background (Upgradient) Welis ........... 3.4

Detection (Downgradient) Wells .......... 3.5

Use of Existing Welts ................. 3.5

Installation of New Characterization/Monitoring Wells . . 3.5

Monitoring Parameters ............. 3.10

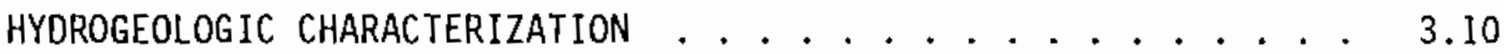

Geologic Characterization ........... 3.12

Hydrologic Characterization .......... 3.13

SCHEDULE OF CHARACTERIZATION AND WELL INSTALLATION ..... 3.17

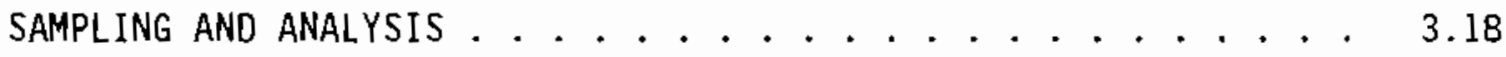

STATISTICAL ANALYSIS OF INDICATOR EVALUATION MONITORING

DATA . . . . . . . . . . . . . . . . 3.18

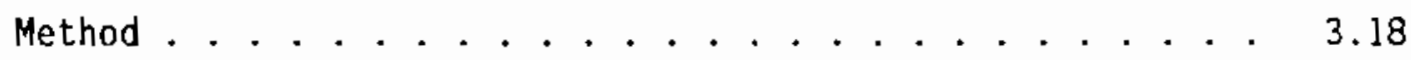

Establishing Background ............. 3.18

EvaTuation of Data......................... 3.19

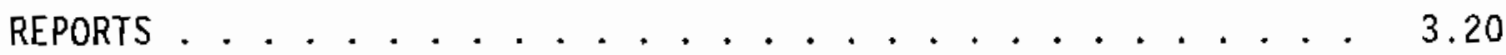

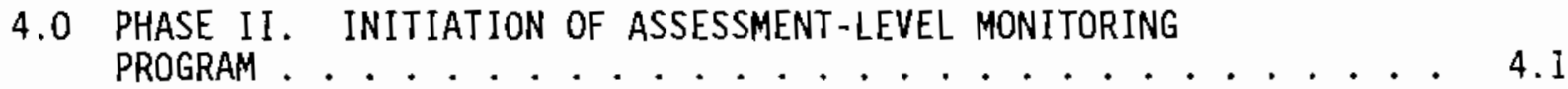

INITIATION CRITERIA . . . . . . . . . . . . 4.1

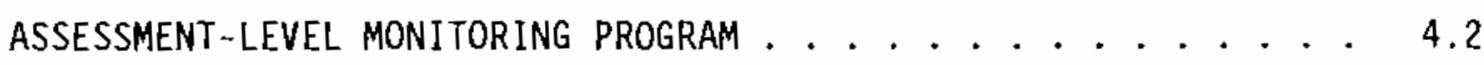

Nature and Extent of Contamination ......... 4.4

Rate of Movement . . . . . . . . . . 4.4

Additional Well Installations . . . . . . . 4.4

Additional Field and Laboratory Testing . . . . . . 4.5 
Modeling................... 4.5

CONTINUED ANALYSIS AND EVALUATION . . . . . . . . . 4.6

Review of Methods and Procedures . . . . . . . 4.6

Review of Sampling Parameters and Frequency ..... 4.6

Notification and Reports............ . 4.6

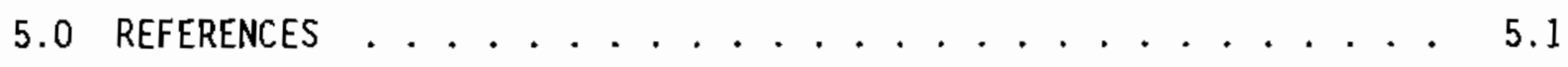

APPENDIX A - DRILLING AND WELL CONSTRUCTION LOGS . . . . . . . . A.1

APPENDIX B - DATA LISTINGS AND SUMMARIES . . . . . . . . . B. B

APPENDIX C - FUNCTIONAL OESIGN AND CONSTRUCTIDN STANDARDS FOR GROUND-WATER MONITORING WELLS .............. C.I

APPENDIX D - SAMPLING AND ANALYSIS PLAN. . . ......... 0.1

APPENDIX E - QUALITY ASSURANCE Plan. . . . . . . . . . E. E. 


\section{FIGURES}

2.I Location of the Hanford Site in Washington State. . . . . . . . 2.2

2.2 Location Map of the 200-East Area and the 2101-M Pond Site................. . . . . . . . . . .

2.3 Location of the 2101-M Pond in Relation to the 2101-M Building................... . . . . . . . . . . .

2.4 Map Showing Structura] Geology of the Pasco Basin....... . 2.8

2.5 Generalized Stratigraphic Column for the Separations Areas................... . . 2.9

2.6 Existing Wells and Geologic Cross Section $A-A^{\prime} \ldots . . . . .2 .13$

2.7 Geologic Cross Section $A-A^{\prime}$. . . . . . . . . . . . . 2.14

2.8 Separations Areas Water-Table Map . . . . . . . . . . . 2.19

2.9 Hater-Table Maps of the U.S. Ecology Site . . . . . . . . 2.23

3.1 Locations of Planned Ground-Water Monitoring Wells . . . . . . 3.2

3.2 Schematic Diagram of a Completed Ground-Water Monitoring Well................... . . . 3.9

3.3 Approximate Schedule for Installation of Monitoring Wells at the 2101-M Pond. . . . . . . . . . . . . 3.17 
$\underline{\text { TABLES }}$

2.1 2101-M Pond Waste Water Analytical Data . . . . . . . 2.6

2.2 Ranges of Hydraulic Properties in the Separations Areas . . . . . . . . . . . . 2.21

2.3 Status of Existing Wells in the Vicinity of the 2101-M Pond ................. 2. 2.25

2.4 Water-Level Elevation Data from Existing Wells Near the 2101-M Pond ............. 2.26

3.1 Ground-Water Sampling Parameters ............. 3.11

3.2 Predicted Drawdowns . . . . . . . . . . . . . . 3.14

3.3 Reports Required by 40 CFR 265 , Subpart F, for Indicator Evaluation Ground-Water Monitoring . . . . . . 3.20

4.1 Sample Assessment-Level Monitoring Plan Out7ine . . . . . . . 4.3

4.2 Reports and Notifications for an Assessment-Level Monitoring Program .............. 4.7 



\subsection{INTROOUCTION}

This chapter presents the purpose, objectives, and scope of the groundwater monitoring plan for the 2101-M pond.

\section{PURPOSE AND OBJECTIVES}

The purpose of this plan is to present an indicator evaluation groundwater monitoring program that is capable of determining the impact on groundwater quality in the uppermost aquifer underlying the 2101-M pond as required by 40 CFR $265.90(a)$. Specific objectives of the plan include

- designing a well network that is able to detect constituents migrating from the site to the ground water

- locating these wells based on the flow paths beneath the facility

- presenting a ground-water sampling and analysis plan

- presenting an outline of the assessment-level program.

\section{SCDPE}

A Resource Conservation and Recovery Act (RCRA) Part A (interim status) permit application has been submitted for the $2101-M$ pond. The pond receives waste water from the 2101-M Building in the 200-East Area. Before 1985, this waste water might have contained hazardous waste and materials; since 1985 , physical controls and operating procedures have been modified to avoid inadvertent discharge of chemicals to the waste-water stream. Because the 2101-M pond is not expected to receive additional hazardous substances, the U.S. Department of Energy, Richland Operations Office (OOE-R!) has proposed that the 2101-M pond be closed under RCRA interim status, although the pond will continue to receive non-RCRA-regulated waste water.

This document is an indicator evaluation ground-water monitoring $p$ lan for the 2101-M pond. This monitoring plan is based on ground-water monitoring requirements for RCRA interim-status facilities. The applicable monitoring requirements are described in 40 CFR 265, Subpart $F$, and Washington Administrative Code (WAC) 173-303 (Ecology 1986). 
This report does not attempt to integrate or document all that is known of the hydrogeologic system within the 200-East Area (part of the Separations Areas). As more characterization efforts are undertaken on the Hanford Site, the understanding of the geologic framework and its relation to the hydrogeologic system will continue to be developed and refined. Future characterization reports will provide analyses of new and updated concepts.

This document presents an overview of the operation of the 2101-M pond, the geology and hydrogeology of the area, and an indicator evaluation ground-water monitoring program (Phase I). If hazardous constituents are detected in the Phase I program, a ground-water quality assessment monitoring program (Phase II) will be initiated. 


\subsection{BACKGROUND INFORMATION}

The DOE's Hanford Site is located in south-central Washington State (Figure 2.1). The Hanford Site is used for nuclear reactor operation, reprocessing of spent fuel, and management of radioactive waste. The fuel reprocessing and radioactive waste management facilities in the 200-East and 200-West Areas (Separations Areas) are operated by Westinghouse Hanford Company.

\section{FACILITY DESCRIPTION}

The 2101-M pond is located within the 200-East Area, which is in the central portion of the Hanford Site. A description and the location of the facility and its past and present waste characteristics are given in this section.

\section{Location and Physical Description}

The 2101-M pond is located west-southwest of the 2101-M Building in the southwestern portion of the 200-East Area (Figure 2.2). The 2101-M pond has received waste water from the 2101-M Building since 1953 via a 4-in. castiron drain line. The pond is a manmade, earthen, unlined, and uncovered U-shaped ditch (Figure 2.3). This pond is approximately $180 \mathrm{ft}$ long on the north and south sides and $70 \mathrm{ft}$ long on the east side. It is approximately 3 to $10 \mathrm{ft}$ wide and 5 to $9 \mathrm{ft}$ deep. The total area occupied by the pond is less than 1 acre. Vegetation is growing in and adjacent to the pond.

The point of discharge to the 2101-M pond is at the southeastern corner. Effluent discharged to the pond is allowed to infiltrate into the soil. Discharge volumes are not metered, but are typically small (DOE 1987). Precipitation runoff from nearby streets and parking lots also enters the southeastern corner of the pond through an open ditch adjacent to the pond.

\section{History}

The 2101-M Building has been used since 1953, with waste water primarily from steam traps and swamp coolers being discharged to the 2101-M pond since that time. The 2101-M Building houses spare parts storage, an electrical 


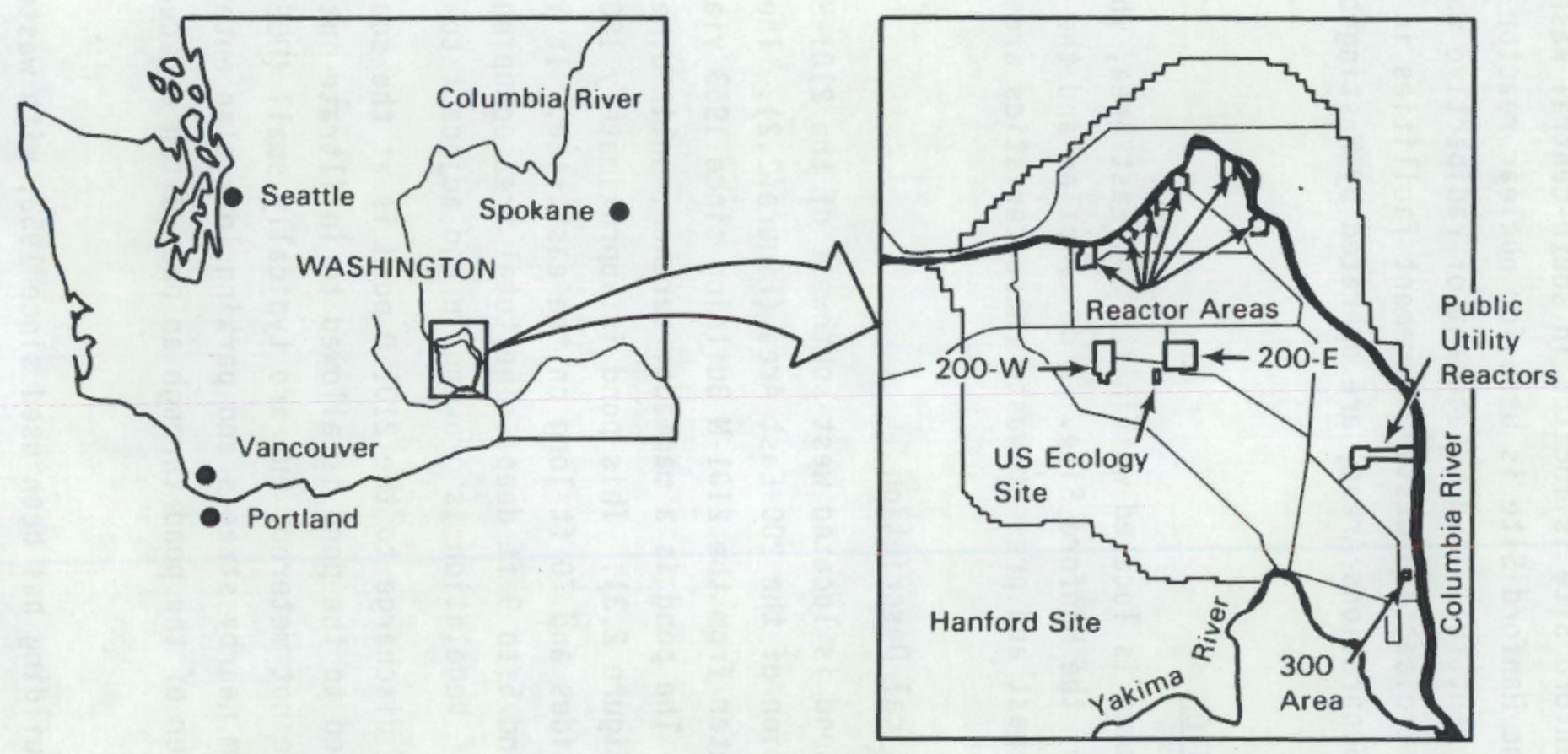

FIGURE 2.1. Location of the Hanford Site in Washington State 


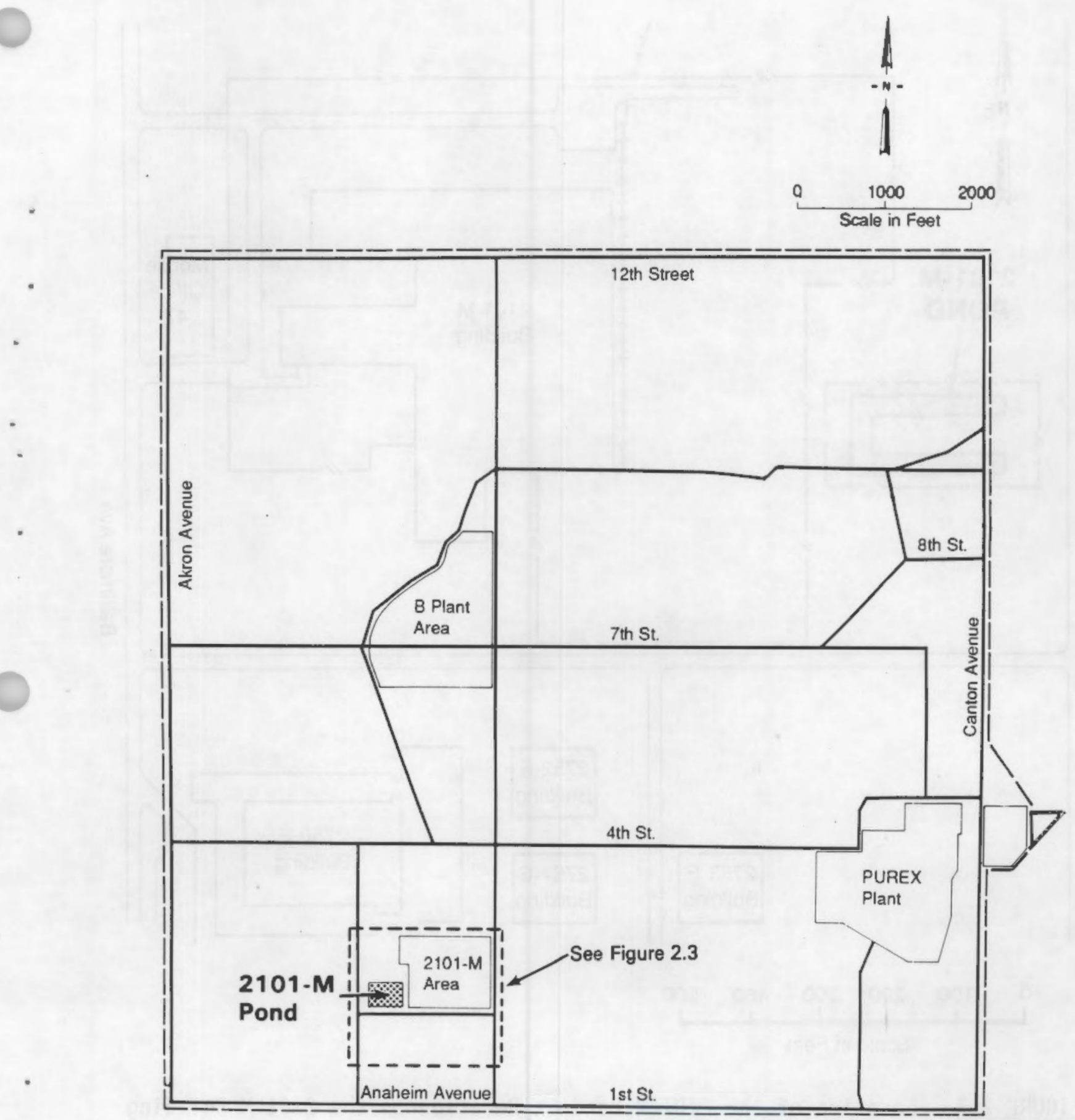

FIGURE 2.2. Location Map of the 200-East Area and the 2101-M Pond Site 


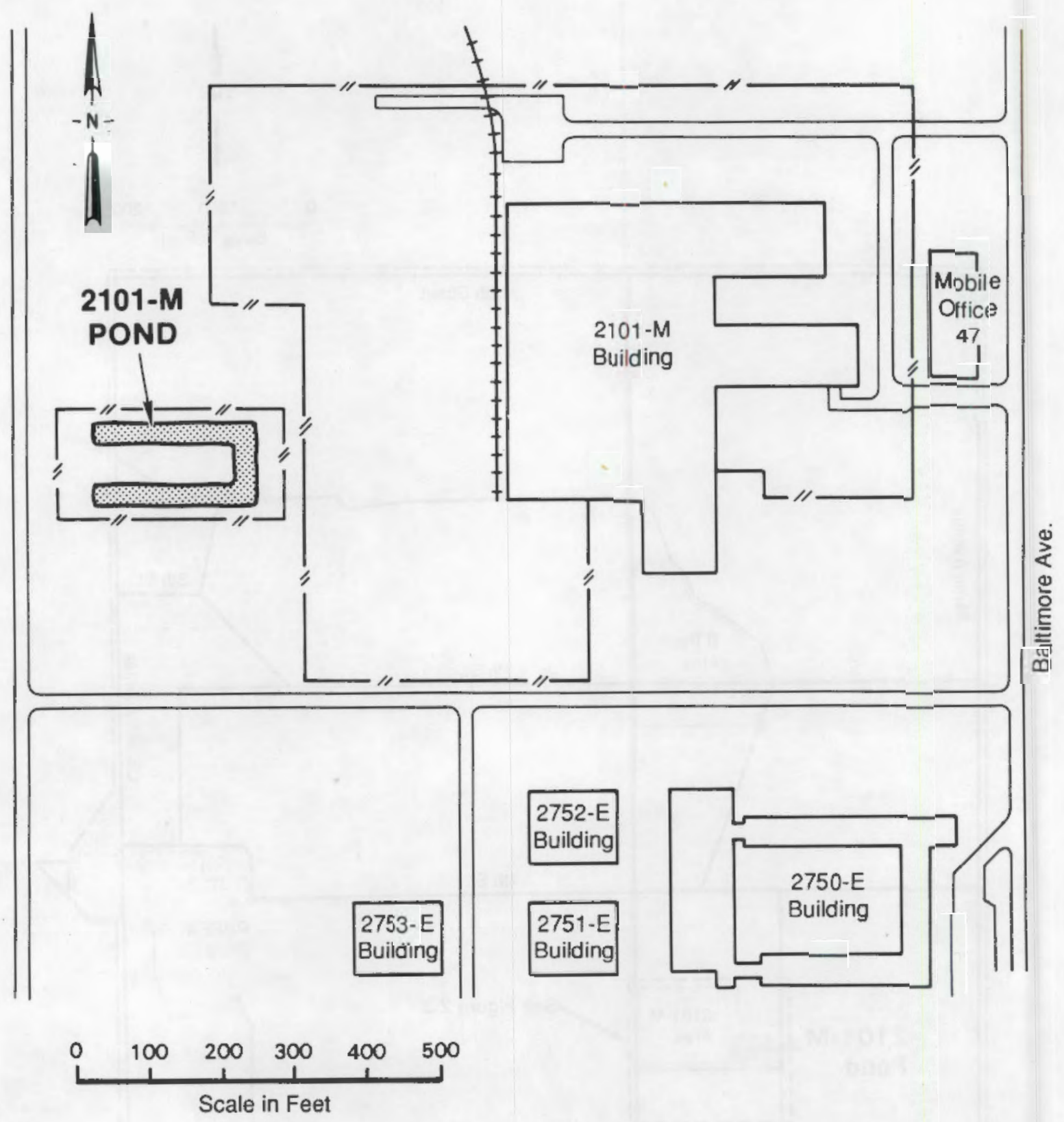

FIGURE 2.3. Location of the 2101-M Pond in Relation to the 2101-M Building 
instrument shop, a high-efficiency particulate air filter test shop, and an insulator's shop and offices. The Basalt Waste Isolation Project (BWIP) laboratory moved into the 2101-M Building in 1980 and was closed in 1987 . No information on the possible discharges of regulated materials to the pond between 1953 and 1980 is currently available.

Between 1980 and July 1985, when BWIP initiated administrative controls to prohibit discharge of hazardous waste, the 2101- $M$ pond received laboratory wastes, including solutions of barium chloride, nitric acid, and hydrochloric acid. Discharges of most materials are estimated to have been less than $1.1 \mathrm{bb} / \mathrm{yr}$, except for barium chloride, nitric acid, and hydrochloric acid that are estimated to have been 2 to $22 \mathrm{lb} / \mathrm{yr}$ from 1983 to July 1985 (DOE 1987). The laboratory hazardous wastes were collected for appropriate disposal from 1985 to 1987 . In 1987 the BWIP laboratory was closed. A complete discussion of the laboratory chemicals that may have been discharged to the pond will be presented in revision 1 of the closure plan for the 2101-M pond.

\section{Current Waste Characteristics}

Samples of the waste water discharged to the pond were taken in 1985, 1986, and 1987 (Jungfleisch 1988). The results of the analyses, given in Table 2.1, indicate recent discharges have been nonhazardous (Jungfleisch 1988). The BWIP laboratory no longer contributes waste water to the pond because the program was shut down in late 1987. Other sources of waste water within the 2101-M Building are still operating, however, and continue to discharge water to the pond.

\section{GEOLOGY}

This section provides background information on the geology of the Hanford Site and the 2101-M pond in support of the indicator evaluation groundwater monitoring program presented in Chapter 3.0. The geology of the Columbia Plateau and particularly the Pasco Basin has been studied in detail for DOE as part of the siting studies for a deep geologic repository for commercial radioactive waste. The Consultation Draft, Site Characterization Plan (DOE 1988) summarizes much of the information known about the Hanford 
TABLE 2.1. 2101-M Pond Waste Water Analytical Data(a)

\begin{tabular}{|c|c|c|c|c|c|}
\hline $\begin{array}{l}\text { Sampling Date } \\
\text { Sampling Number } \\
\text { Stream Fraction }\end{array}$ & $09 / 17 / 85$ & $\begin{array}{l}\text { 2nd } \\
05 / 23 / 86 \\
50051 \\
1.0000 \\
\end{array}$ & $\begin{array}{c}\text { 3rd } \\
07 / 17 / 86 \\
50089 \\
1.0000 \\
\end{array}$ & $\begin{array}{l}4 \text { th } \\
10 / 30 / 86 \\
50167 \\
1.0000 \\
\end{array}$ & $\begin{array}{l}5 \text { th } \\
01 / 26 / 87 \\
50232 \\
1.0000 \\
\end{array}$ \\
\hline Uim I I I & & & & & +02 \\
\hline ium (ppb) & & & & & +02 \\
\hline mony (ppb) & & $<1$. & $<1$. & $<1$. & $<1.0 E+02$ \\
\hline $\operatorname{lm}(p p b)$ & & & & & +01 \\
\hline lium (ppb) & & $<5$. & & $<5.0 \mathrm{E}$ & +00 \\
\hline um $(p p b)$ & & $<2$. & & & $<2$. \\
\hline um (ppb) & & $1.7 \mathrm{E}+$ & $\operatorname{NIC}(b)$ & $1.1 \mathrm{E}$ & 03 \\
\hline ium (ppb) & & $<1.0 \mathrm{E}+$ & $<1.0 \mathrm{E}+$ & $<1.0 E+01$ & $<1$. \\
\hline$(p p b)$ & & & & & 02 \\
\hline$(p p b)$ & & & $2.8 \mathrm{E}+02$ & $3 E+03$ & 02 \\
\hline ead (ppb) & +01 & No (c) & NR $(\mathrm{C}$ & & $<5$ \\
\hline agnesium ( $p p b)$ & & 4. & 4. & & \\
\hline Inese (ppb) & & & & & \\
\hline ry (ppb) & & & & $<1$. & $<1$. \\
\hline ickel (ppb) & 1 & $<1$. & $<1$. & $<1$. & $<1$. \\
\hline sium (ppb) & & & & & \\
\hline ilver (ppb) & & $<1$. & $<1$ & $<1$. & $<1$ \\
\hline dium (ppb) & & & NIC (b) & & \\
\hline ium (ppb) & $<3$ & $<3$. & $<3$. & $<3$. & $<3$ \\
\hline Im $(p p b)$ & & & & & \\
\hline ium (ppb) & $<5$ & $<5$. & & $<5$ & 00 \\
\hline$(p p b)$ & & & & & \\
\hline ride ( $p p b)$ & & & & & \\
\hline de (ppb) & & $<1$. & & $<1$. & $<1$ \\
\hline ide (ppb) & & $<$ & $<5$. & & \\
\hline e $(p p b)$ & & $<$ & & & \\
\hline hate (ppb) & & $<$ & & & \\
\hline ide ( $p p b)$ & & & & & \\
\hline fate (ppb) & 1. & 1.3 & & & \\
\hline he (ppb) & & $<1$. & $<1$. & & $<1$ \\
\hline oform (ppb) & & & & $<1$. & $<1$ \\
\hline$t(L / m o)$ & 3.8 & 3.8 & & 3.8 & \\
\hline imensionle & & & & & \\
\hline rature (ce & & & & & \\
\hline Activity & & $<4$. & & & $<5$ \\
\hline Activity & & & & & \\
\hline uctivity ( & & & & & \\
\hline anic & & & & & \\
\hline $1+10$ & 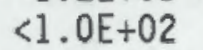 & & & -02 & \\
\hline
\end{tabular}

(a) Modified from Jungfleisch (1988).

(b) NIC = measurements made by methods that were not in control.

(c) $\quad N R=$ data not recorded.

(d) HTE = measurements made after holding times were exceeded. 
Site, especially near the 200 -West Area, where the reference repository site was located. Studies have also been done in support of nuclear power plant licensing efforts, including those for the Washington Public Power Supply System (Supply System 1981) and the Skagit/Hanford Project (PSPL 1982). More detailed information is available in the following reports:

- on the structural geology and tectonics - Caggiano and Duncan (1983) and Reidel, Fecht, and Cross (1982)

- on the basalt stratigraphy and chemistry - Swanson et al. (1979) and Reidel, Fecht, and Cross (1982)

- on the sedimentary units interfingered with and overlying the basalts - Bjornstad (1984); Fecht, Reide1, and Tallman (1985); Myers/Price et a1. (1979); and Myers and Price (1981). Tallman et al. (1979) is the only in-depth study of the geology of the Separations Areas.

\section{Regional Geologic Setting}

The Hanford Site lies within the Columbia Plateau, which is generally characterized by a thick sequence of basalt flows. These flows have been deformed, creating broad structural and topographic basins separated by asymmetric anticlinal ridges. Sediments have accumulated in the basins. The Hanford Site lies within one of these, the Pasco Basin (Figure 2.4).

Principal geologic units within the Pasco Basin include, in ascending order, the Columbia River Basalt Group (Miocene), the Ringold Formation (Miocene-Pliocene), the Plio-Pleistocene unit (Pliocene/Pleistocene), the early "Palouse" soil (Pleistocene), and the Hanford formation (Pleistocene). A regionally discontinuous veneer of recent alluvium, colluvium, and eolian sediments overlie the principal geologic units.

\section{Geology of the Separations Areas}

A generalized stratigraphic column is given in Figure 2.5. Surrounding and plunging into the structural Pasco Basin are anticlinal ridges and synclinal valleys. The crest of one of these anticlinal ridges, the UmtanumGable Mountain structure, lies north of the Separations Areas, while the axis 


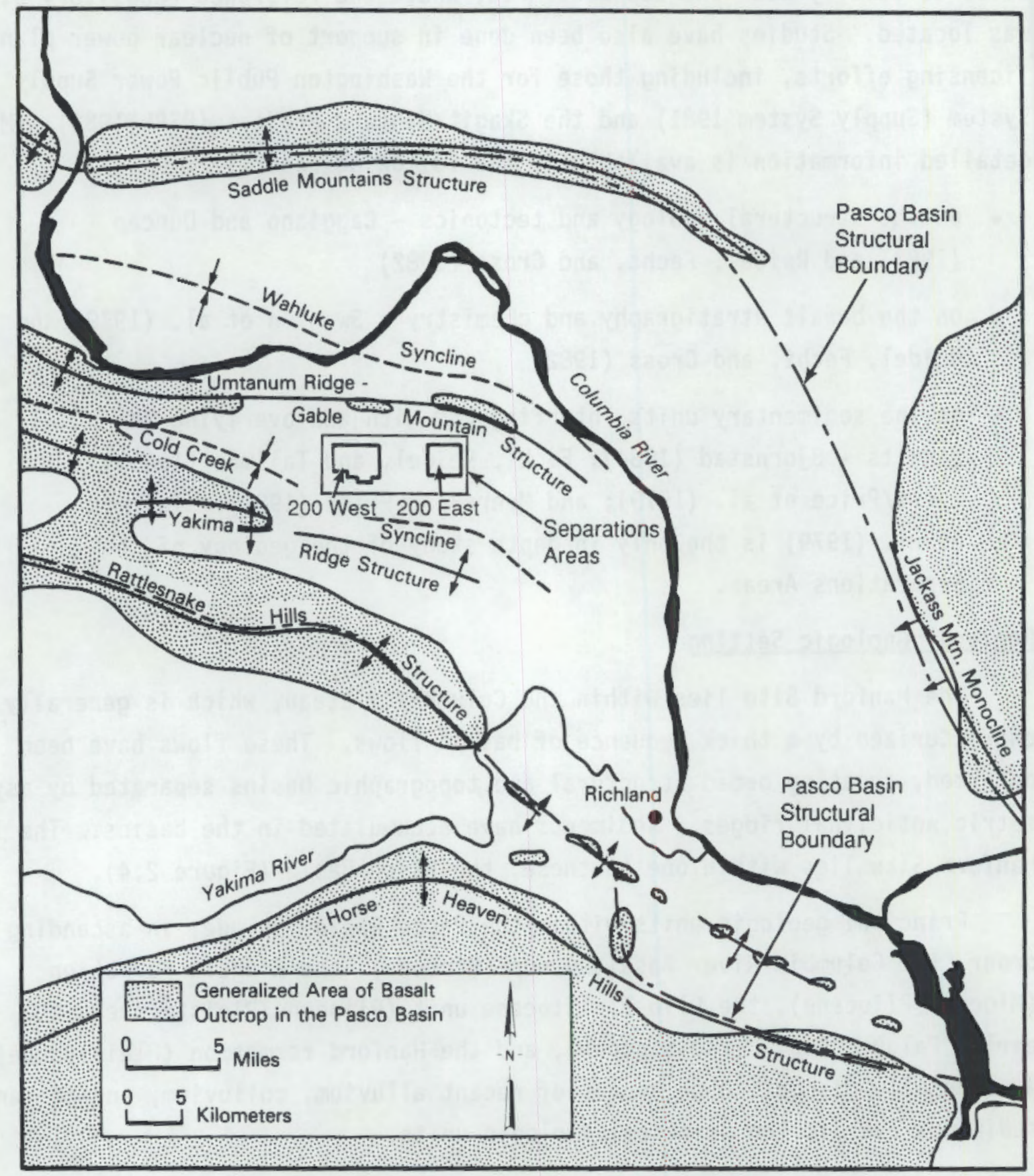

FIGURE 2.4. Map Showing Structural Geology of the Pasco Basin 


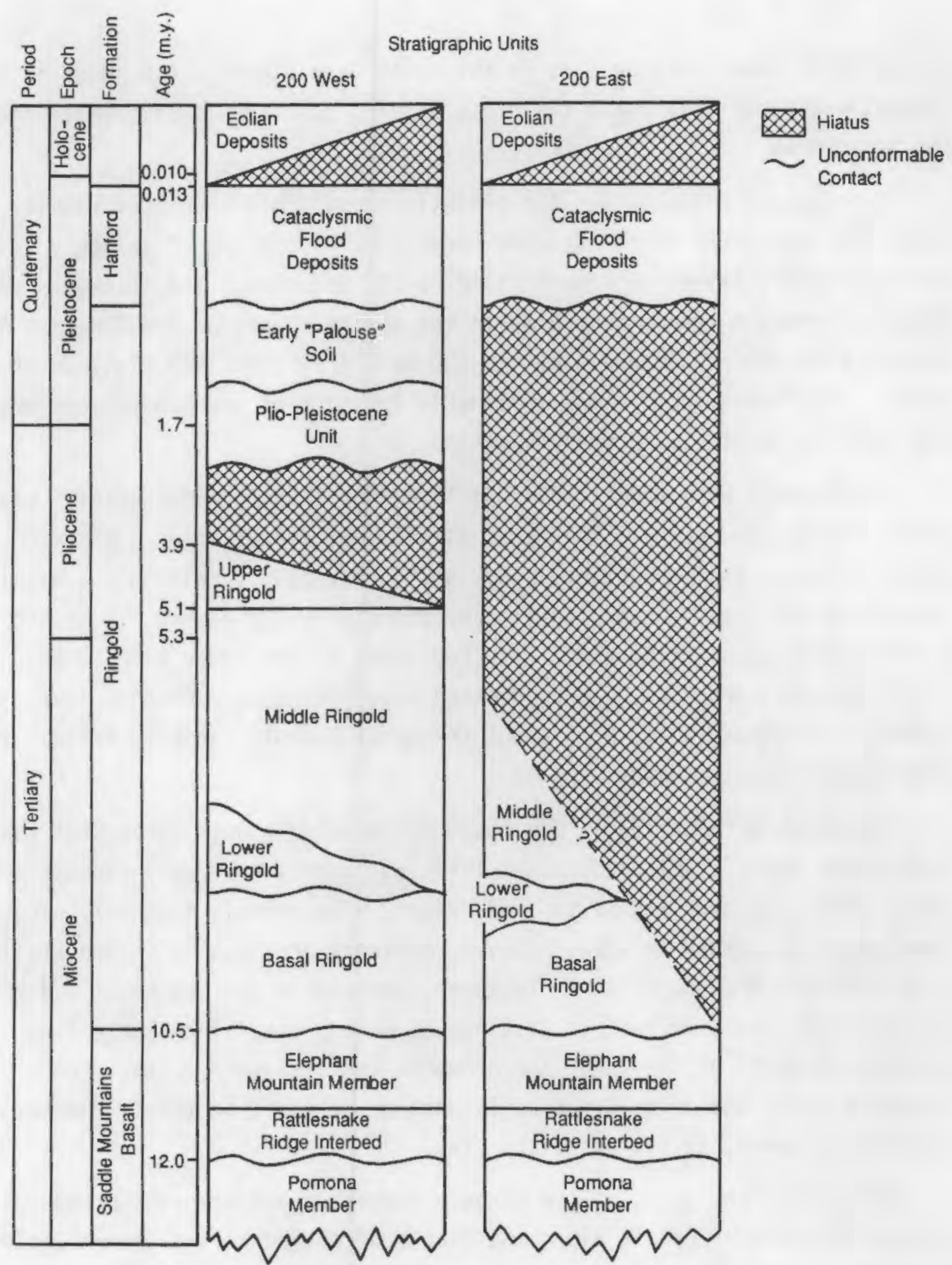

FIGURE 2.5. Generalized Stratigraphic Columns for the Separations Areas 
of the Cold Creek syncline lies to the south (see Figure 2.4). Much of the Separations Areas lies above the south-dipping basalt surface between these two structures.

Overlying the basalt are the slightly to strongly indurated fluvial and lacustrine sediments of the Ringold Formation, consisting of variably mixed and interbedded layers of gravel, sand, silt, and clay. The thickness of the Ringold Formation ranges from $0 \mathrm{ft}$ in the northern part of the 200-East Area to more than $700 \mathrm{ft}$ southwest of the 200-West Area (DOE 1988; Tallman et a1. 1979). The formation thickens substantially south of the Separations Areas near the axis of the Cold Creek syncline.

The Ringold Formation is divided into four stratigraphic units: basal, lower, middle, and upper. The basal Ringold unit consists of silty sandy gravel overlain by fine-grained sand, silt, or clay. Overlying the basal Ringold is the lower Ringold unit, consisting of silty coarse- to mediumgrained sand, sandy silt, and clay. Sediments of the lower Ringold unit are often indurated and have been recognized as a potential confining layer in places. The fine-grained portion of the basal Ringold can be difficult to distinguish from the lower Ringold.

The Ringold Formation is dominated by the middle unit throughout the Separations Areas. The predominant 1ithology consists of we11-rounded sandy gravel with some sand and silty sand lenses. The gravels typically range from pebble to cobble in size; however, boulders are 1 acally common (Tal1man et a1. 1979). Because of their textures, the coarse-grained basal and middle Ringold units are difficult to distinguish unless separated by the finegrained sediments of the lower and/or upper basal Ringold units. The uppermost unit, the upper Ringold, is another sequence of thinly bedded, well-sorted sands, silts, and silty clay.

Not all of the units of the Ringold Formation are present throughout the Separations Areas. Uplift along the flanks of the anticlinal ridges, along with erosion by the ancestral Columbia River and catastrophic flooding during the Pleistocene, have removed or prevented deposition of some or all of the Ringold Formation in areas (Bjornstad 1984; Tallman et al. 1979). All four units are currently identified only in the western and southern portions 
of the 200-West Area, while no units of the Ringold Formation are present in the northeastern part of the 200-East Area.

A well-developed caliche horizon and/or locally derived basaltic gravel, informally called the Plio-Pleistocene unit, is found on the uppermost surface of the eroded Ringold sediments in the western portion of the Pasco Basin. This unit can be up to $80 \mathrm{ft}$ thick (Bjornstad 1984). In places, the Plio-Pleistocene unit is overlain by the early "Palouse" soil, an eolian deposit of fine-grained sand and silt. Both of these units are found only in the 200-West Area, having either been eroded or not deposited in the 200-East Area.

The catastrophic flooding that helped erode the Ringold Formation also deposited a sequence of unconsolidated silts, sands, and gravels informally named the Hanford formation. The fine-grained sands and silts, called the Touchet Beds, were deposited in protected areas, while the Pasco Gravels were deposited in and near the floodwater channels. Thickness of the formation ranges from approximately $70 \mathrm{ft}$ in part of the 200-West Area to a maximum of approximately $350 \mathrm{ft}$ east of the 200-East Area (Tallman et a1. 1979). Within much of the southern portion of the Separations Areas, the Hanford formation consists of sand.

The contact between the Hanford and Ringold Formations is commoniy distinguished by a transition upward from more indurated deposits containing a variety of lithologies (Ringold Formation) to very weakly cemented or unconsolidated sediments with a high proportion of basaltic gravels (Hanford formation). The texture of the Pasco Gravels and the middle Ringold unit are similar, although the difference in gravel lithologies can be used to distinguish between the two. However, in some places, basalt-rich gravel layers have been found in the middle Ringold unit, and if the middle Ringold and Pasco Gravels are not separated by the upper Ringold or early "Palouse" soil, they can be difficult to distinguish. This is particularly true where considerable reworking and incorporation of the Ringold sediments into the Hanford formation has occurred. Other methods of defining the contact between the two formations are currently being evaluated. Further work, including 
this project, will also help determine the position of the contact more precisely. Locally, the Hanford formation is overlain by a thin (0- to $10-\mathrm{ft}$ ) veneer of fine-grained eolian sand.

Typically, the sediments in the 200-East Area contain little calcium carbonate, and to date no caliche horizons have been identified. Where present, cementation of the Ringold Formation is generally by siliceous material.

\section{Stratigraphy Beneath the 2101-M Pond}

Information on the geology beneath the 2101-M pond has been summarized from well log data collected during previous drilling and well installations in the area (Appendix A). Drilling logs were reviewed for two wells located within $2000 \mathrm{ft}$ of the pond (see Figure 2.6). The cross section in Figure 2.7 i1lustrates the stratigraphy at the pond, based on data from these logs.

The depth to basalt beneath the 2101-M pond is not precisely known. Basalt was encountered at a depth of $445 \mathrm{ft}$ in we11 299-E23-2, located approximately $1700 \mathrm{ft}$ northeast of the pond, and at a depth of $524 \mathrm{ft}$ in well 299-E19-1, located approximately $1600 \mathrm{ft}$ southwest of the pond (see Figures 2.6 and 2.7). The thickness of the sediments overlying the basalt beneath the $2101-M$ pond is approximately $490 \mathrm{ft}$, based on interpolation between those two wells.

The present level of subsurface information precludes any definitive distinction between the Hanford and Ringold Formations in the vicinity of the 2101-M pond. Therefore, the following discussion provides only a general description of the textures identified in two wells near the pond, 299-E19-1 and 299-E23-2.

The sediments in this part of the 200-East Area may be divided into five major textural units. These units are, in ascending order, a clayey sandy gravel, a silty sandy cobble-to-boulder gravel, a clay, a silty gravelly sand, and a silty sand (see Figure 2.7). The clayey sandy gravel (44 ft thick) and the clay (58 ft thick) units occur only in we11 299-E19-1, apparently pinching out to the north before reaching well 299-E23-2. It is unknown whether these units occur beneath the pond. 


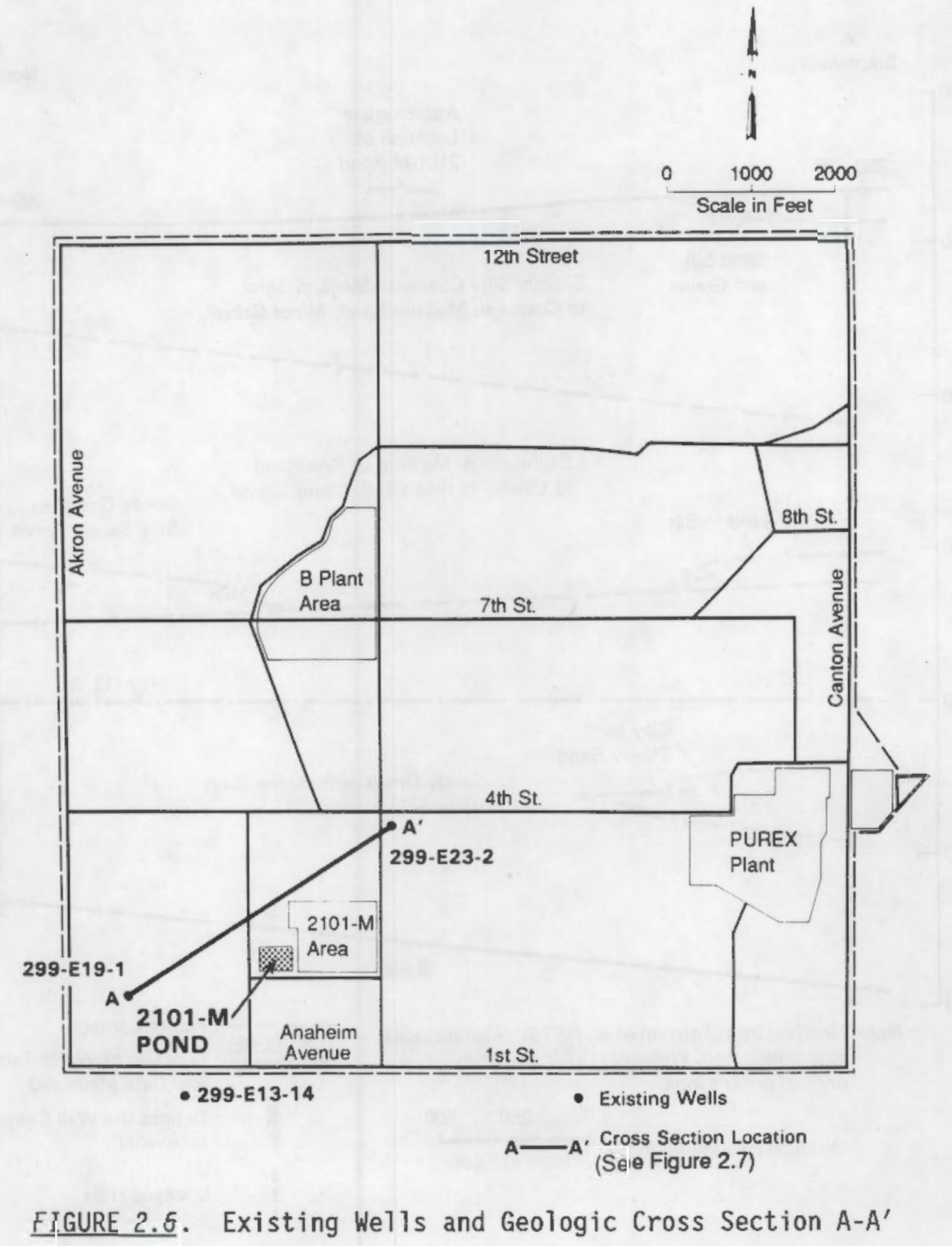


A

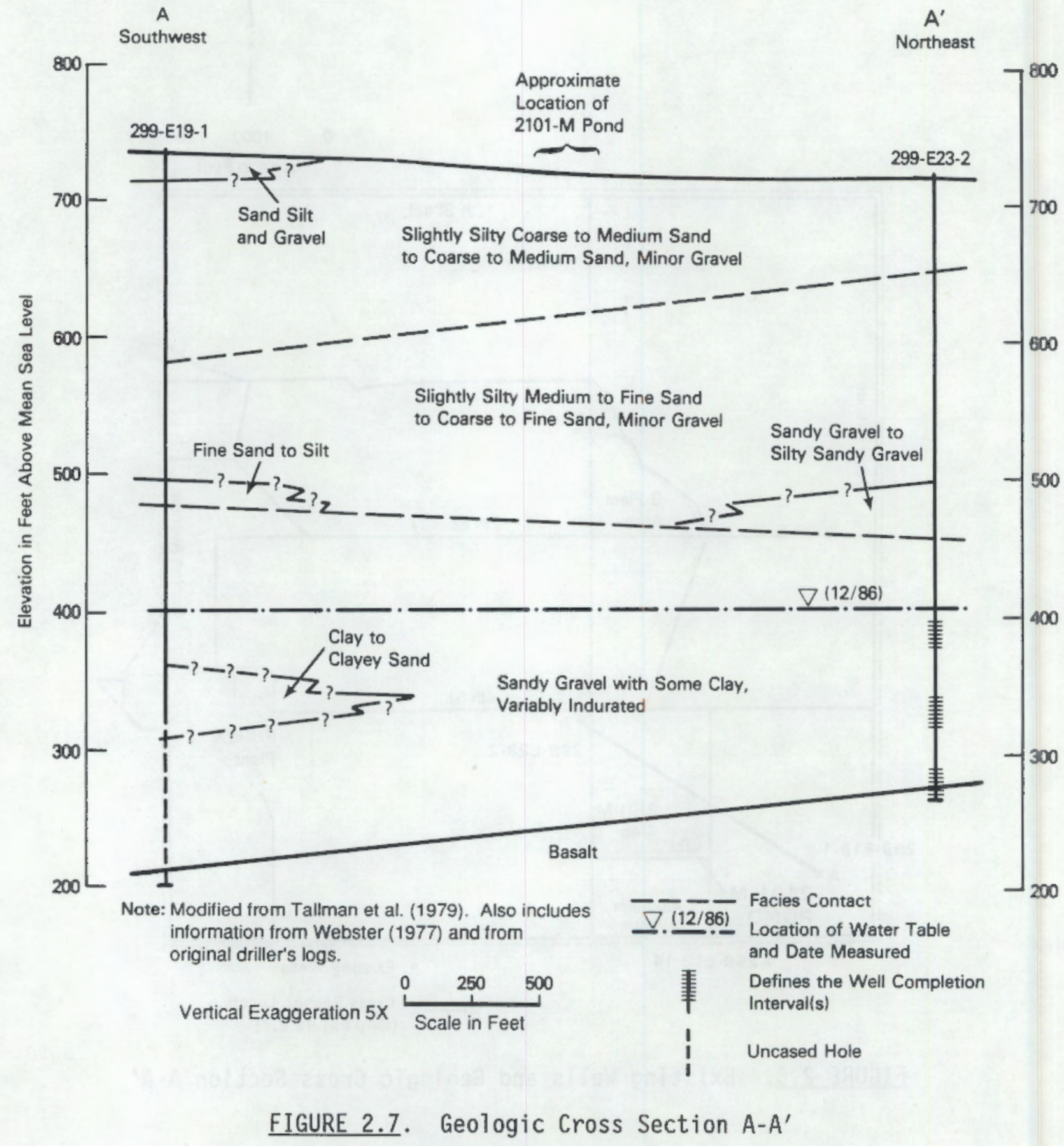


The lowermost continuous textural unit is the indurated silty sandy cobble-to-boulder gravel unit, which occurs directly above the basalt in well 299-E23-2. Its thickness ranges from approximately 60 to $88 \mathrm{ft}$. This unit is distinguished from the silty gravelly sand to silty sandy gravel overiying it by the lack of cementation in the latter. Near the top of the middle Ringold unit in well 299-E19-1 is a 15-ft-thick layer of fine sand and silt. The extent of this fine-grained layer to the north is unknown. Overall, the middle unit's thickness ranges from approximately 135 to $170 \mathrm{ft}$.

The uppermost unit is approximately $200 \mathrm{ft}$ thick and consists predominantly of silty sand. Interbedded gravelly sands occur southwest of the pond (well 299-E19-1), while sand makes up much of the unit toward the northwest (well 299-E23-2). The lateral extent of the gravelly sands is unknown.

The surface in the vicinity of the 2101-M pond has been disturbed by past construction activities. Surface sediments generally consist of silty gravelly sand to sand, which grades into the underlying silty sand unit.

\section{HYDROGEOLOGY}

This section provides background information on the hydrogeology of the Hanford Site. Detailed descriptions of the area's hydrogeology are available in reports by DOE (1988); Gephart et a1. (1979); Graham et a1. (1981); Graham, Last, and Fecht (1984); and Law, Serkowski, and Schatz (1987), and water-level data collected and reported semiannually, such as Schatz and Ammerman (1988).

\section{Regional Setting}

The Hanford Site has an arid climate and receives an average of 6.25 in. of precipitation a year. Evaporation rates are expected to far exceed this (DOE 1988); therefore, most precipitation likely is transpired or evaporated back to the atmosphere (Graham et al. 1981). Recharge rates range from near zero to more than $4 \mathrm{in./yr}$, depending on surface conditions (Gee 1987). Small recharge rates generally occur where fine-textured sediments and deeprooted plants occur. The larger values are associated with areas having a 
coarse gravelly surface and no vegetative cover. The Hanford Site is drained by the Yakima and Columbia rivers (see Figure 2.4).

Ground water beneath the Hanford Site occurs under both unconfined and confined conditions. The unconfined aquifer is contained primarily within the middle unit of the Ringold Formation and extends up into the Hanford formation in some areas. The base of the unconfined aquifer is the uppermost basalt flow of the Columbia River Basalt Group or, in some areas, the clay of the lower Ringold Formation (see Figure 2.7). The confined aquifers beneath the Hanford Site generally consist of sedimentary interbeds and interflow zones that occur between dense basalt flows of the Columbia River Basalt Group. Because the Elephant Mountain Basalt is assumed to be an effective confining layer between the unconfined and confined aquifers in most of the Separations Areas, this discussion is limited to the hydrologic properties of the uppermost portion of the unconfined aquifer contained in the Hanford and Ringold Formations.

The source of naturat recharge to the unconfined aquifer and some of the confined aquifers is rainfall from areas of high relief west of the Hanford Site and ephemeral streams in the Cold Creek and Dry Creek valleys. Discharge from the unconfined aquifer is primarily to the Columbia River, with lesser amounts of discharge to the Yakima River (Graham et al. 1981). Ground-Water Hydrology of the Separations Areas

The unconfined aquifer receives artificial recharge from liquid disposal areas. This artificial recharge is estimated to be 10 times greater than natural recharge (Graham et al. 1981). The major sources of artificial recharge in the northern Hanford Site have been three waste ponds designated $U$ Pond, Gable Mountain Pond, and B Pond, all located near or in the Separations Areas. These areas of artificial recharge have had a major effect on the flow system of the unconfined aquifer. Both $U$ Pond and Gable Mountain Pond were decommissioned within the past 4 years. B Pond is scheduled for decomissioning in the 1990s.

The depth to water of the unconfined aquifer within the Separations Areas ranges from approximately $190 \mathrm{ft}$ beneath the former $U$ Pond to approximately $340 \mathrm{ft}$ west of the 200 -East Area. The thickness of the unconfined 
aquifer ranges from $0 \mathrm{ft}$ at the north edge of 200-East Area to more than $250 \mathrm{ft}$ in the northwestern part of 200-West Area.

Ground-water elevation contours for December 1987 (Schatz and Ammerman 1988) for the unconfined aquifer in the Separations Areas are shown in Figure 2.8. The regional flow direction in the Separations Areas is from west to east, but is affected by the two ground-water mounds that have resulted from discharges to $U$ Pond and B Pond. Ground-water flow beneath the 200-West Area is generally toward the north and the east, away from the mound created by past discharges to $\mathrm{U}$ Pond. The horizontal hydraulic gradient in the 200-West Area is sufficiently high, partiy because of the mound, to determine flow directions with a large degree of certainty. Vertical hydraulic gradients are also present within the unconfined aquifer in portions of the 200-West Area as a result of the ground-water mound. As this mound dissipates because of the discontinuance of discharges to $U$ Pond, the horizontal hydraulic gradient will decrease and shift to a more easterly direction, and the vertical gradient will decrease.

Discontinuous perched water tables occur in parts of the 200-West Area, often lying above the caliche horizon in the Plio-Pleistocene unit or above markedly finer grained sediments in the Hanford Formations and upper Ringold. The lateral extent of these perched water tables has not been defined in detail. Perched water is generally found only near sources of discharge of large quantities of water to the sediment column in the Separations Areas.

Ground-water flow beneath the 200-East Area is complex because flow converges from the west and east and then diverges with a component flowing northward between Gable Butte and Gable Mountain and another component flowing southeast toward the Columbia River. In addition, the high transmissivity beneath most of the 200-East Area results in very small hydraulic gradients, ranging from $10^{-4}$ to $10^{-5} \mathrm{ft} / \mathrm{ft}$. Flow directions shift because of changing rates of waste-water discharge into $B$ Pond and other disposal sites. Therefore, it is often difficult to define flow directions at specific sites.

The principal geologic units controlling the ground-water flow in the Separations Areas are, in ascending order, the Elephant Mountain Basalt, 
which generally forms the base of the unconfined aquifer, and the Ringold and Hanford formations, which contain the unconfined aquifer (see Figure 2.5).

The Ringold Formation exhibits a variety of hydrologic characteristics, including hydraulic conditions ranging from confined to unconfined. In some areas, the lower Ringold unit is the base of the unconfined aquifer. In the southern portion of the 200-East Area and much of the 200-West Area, the basal Ringold unit is locally confined by the overlying lower Ringold unit (Graham, Last, and Fecht 1984). In other areas, the lower Ringold unit is missing, and the basal and middle Ringold units contain the unconfined aquifer. Textural changes, vertically between formations and laterally within them, cause the unconfined aquifer to exhibit widely varying hydraulic properties (Table 2.2). The values given in this table are generalizations; in some locations, hydraulic properties lie outside the ranges given.

In general, the Hanford formation contains only the upper portion of the unconfined aquifer, but in the northeastern part of the 200-East Area where the Ringold Formation is missing, the unconfined aquifer is totally within the Hanford formation. The ranges in hydrologic properties for the Hanford formation in the Separations Areas are also given in Table 2.2.

In the 200-West Area, the unconfined aquifer occurs within the middle Ringold unit, which is often at least partially cemented. Transmissivities range from 300 to $5400 \mathrm{ft}^{2} / \mathrm{d}$. In the 200-East Area, the aquifer is in either the unconsolidated Hanford formation, the middle Ringold unit, or both, leading to a wide range of transmissivities from 5 to $135,000 \mathrm{ft}^{2} / \mathrm{d}$ (Graham et a T. 1981).

\section{Ground-Water Hydrology Beneath the 2101-M Pond}

Previous hydrologic investigations in the 200-East Area have focused on areas to the north and east of the 2101-M pond. The impetus for conducting hydrologic investigations in those areas has been an evaluation of $B$ Pond, Gable Mountain Pond, and other liquid waste disposal facilities in and near the 200-East Area. Unfortunately, very little data are available on hydrologic properties near the $2101-M$ pond. 


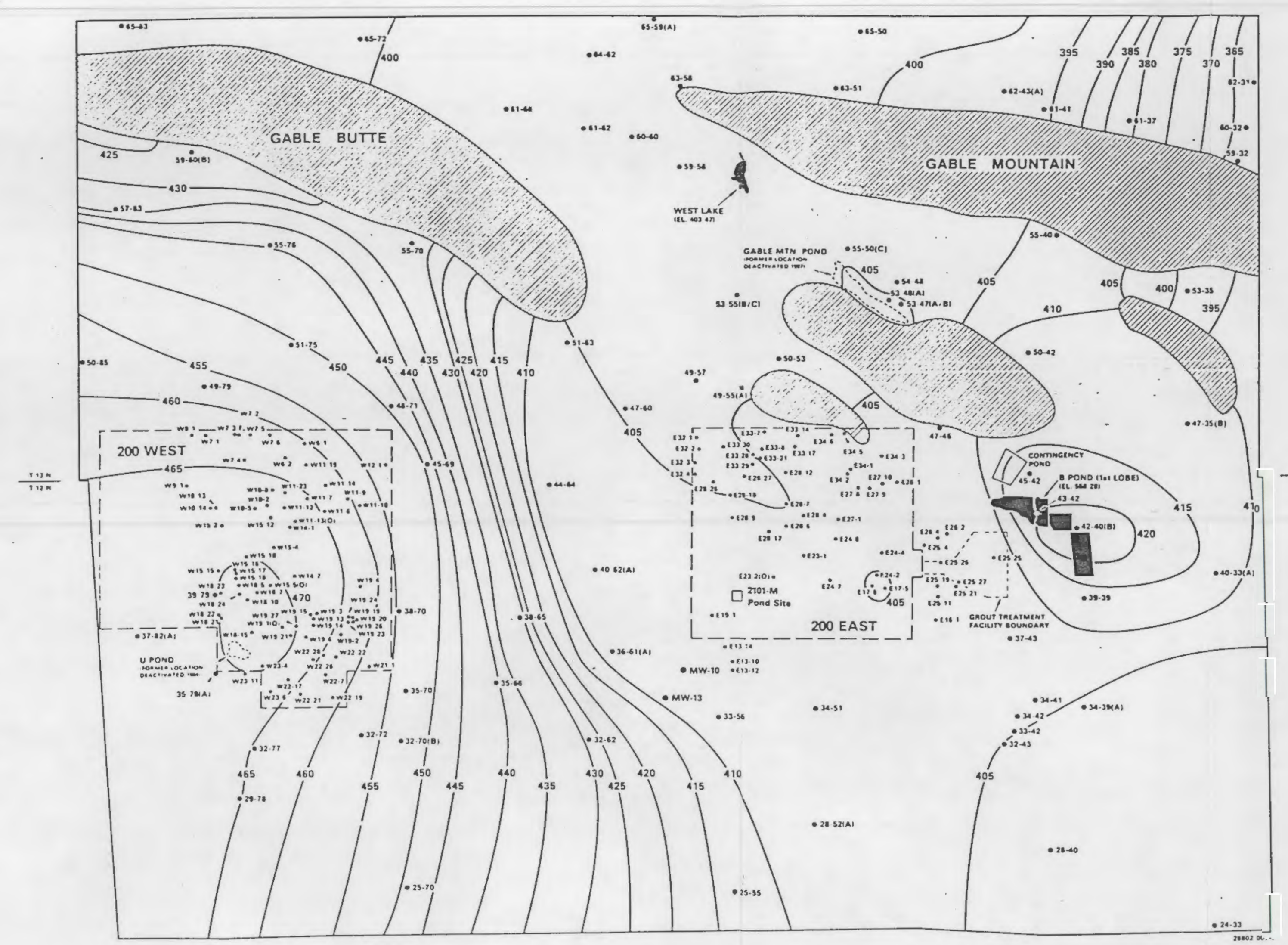

W. Westinghouse Hanford Company WHC-EP-0142

\section{SEPARATIONS AREA}

DECEMBER 1987

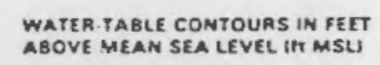

- ave foot contoun

Ponos. waten surfac

TOS BASALT OUTCROPS ABOVE WATEA.

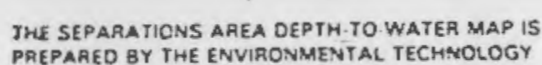

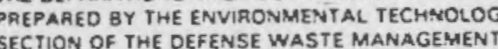

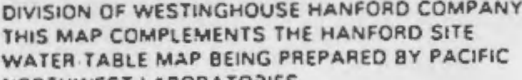
$\frac{i n n}{12 n}$

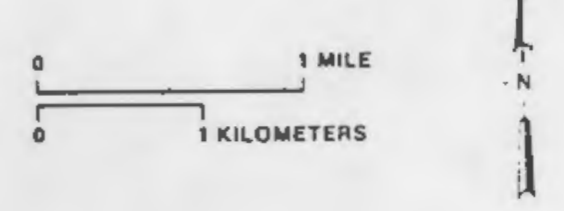

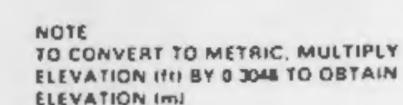

FIGURE 2.8. Separations Areas Water-Table Map (from Schatz and Ammerman 1988) 

TABLE 2.2. Ranges of Hydraulic Properties in the Separations Areas(a)

\begin{tabular}{|c|c|c|c|c|}
\hline Interval Tested & $\begin{array}{l}\text { Hydraul ic } \\
(\mathrm{m} / \mathrm{d}) \\
\end{array}$ & $\begin{array}{c}\text { Conductivity } \\
\text { (ft/d) }\end{array}$ & Storativity & Porosity (\%) \\
\hline Hanford formation & $600-3,000$ & $2,000-10,000$ & 0.07 & 30 \\
\hline Middle Ringold Unit & $3-70$ & $9-230$ & -- & -. \\
\hline Lower Ringold Unit & $1-3.6$ & $1-12$ & 0.002 & 10 \\
\hline
\end{tabular}

(a) From Graham et al. 1981.

\section{Vadose Zone Characteristics and Contamination}

The geology of the site was discussed earlier in the section on stratigraphy beneath the 2101-M pond. No information is available at this time on the presence or extent of contamination within the vadose zone at this site. Shallow holes in the pond are currently being sampled for analysis. The results of these analyses will provide information on the near-surface contamination.

\section{Unconfined (Uppermost) Aquifer}

The unconfined aquifer is the uppermost aquifer and is, therefore, of primary interest for ground-water monitoring.

Data collected from existing wells near the 2101-M pond show that the upper portion of the unconfined aquifer beneath the pond is probably contained within silty sandy gravel to gravelly sand. Well logs indicate that this unit is relatively unconsolidated at the water table (approximately $315 \mathrm{ft}$ deep), but that it becomes more cemented at depth (see Figure 2.7).

During drilling of well 299-E19-1, southwest of the 2101-M pond, a $50-\mathrm{ft}$-thick sequence of clay at a depth of approximately $375 \mathrm{ft}$ below ground surface was encountered. This clay unit is not present northeast of the pond at well 299-E23-2. It is not known whether this clay unit is present beneath the pond. At well 299-E19-1, the clay is relatively indurated and may form a 
confining layer. If that is the case, the clay, rather than the top of the basalt, would then be the base of the unconfined aquifer and the aquifer would be approximately $65 \mathrm{ft}$ thick.

However, if the clay unit at well 299-E19-1 pinches out southwest of the pond, then the bottom of the unconfined aquifer would be the uppermost basalt flow at a depth of approximately 470 to $500 \mathrm{ft}$ below ground surface. If this is true, the thickness of the unconfined aquifer beneath the pond is expected to be between 150 and $200 \mathrm{ft}$.

Because the 2101-M pond is located in the vicinity of a ground-water divide, it is difficult to predict with confidence the direction of groundwater flow immediately beneath the pond. In addition, the hydraulic gradient is so small that measurement error could be responsible for incorrectly determining the direction of ground-water flow beneath the pond (see Figure 2.8). No useful water-level data are available from well 299-E19-1, located to the southwest (see Figure 2.6) because it is currently plugged with drilling mud (see Appendix A). Water-level data from the U.S. Ecology commercial waste disposal site, located less than 1 mile southwest of the pond (see Figure 2.1), indicate a flow direction to the northeast (see Figures 2.8 and 2.9). Based on these data, site-wide water-level measurements (see Figure 2.8), and contaminant plumes (Law, Serkowski, and Schatz 1987), the ground water is expected to flow toward the northeast. Because of the low gradient, however, changes in discharges to the nearby waste-water disposal facilities could influence the flow direction.

The effects of recharge from the 2101-M pond on the ground water were evaluated to predict the amount of mounding that could occur and the potential for vertical ground-water flow resulting from this mounding; these effects were evaluated using a three-dimensional model (McDonald and Harbaugh 1984) and inducing recharge to the model. The model was set up with five layers each $10 \mathrm{ft}$ thick, and a 50 - by 50 - node grid with a 20 -ft spacing between nodes. A transmissivity of $20,000 \mathrm{ft}^{2} / \mathrm{d}$ and a horizontal-to-

vertical anisotropy ratio of $5: 1$ was assigned. The initial head was set the same at every node. A recharge rate of $18,000 \mathrm{gal} / \mathrm{d}$ was induced on an 80 - by 120-ft area in the center of the grid. The model was run at steady state. 


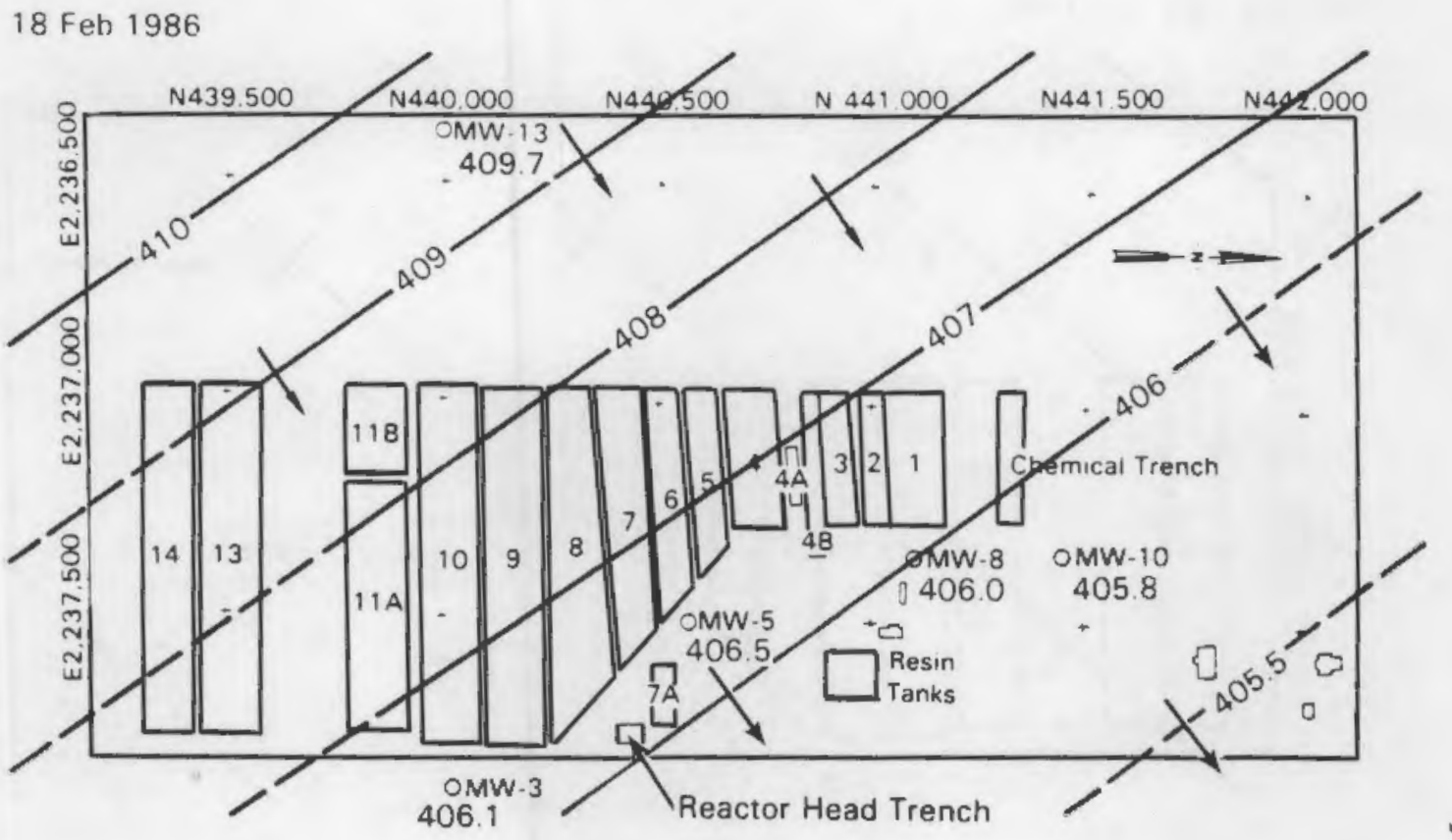

30 April - 1 May 1986

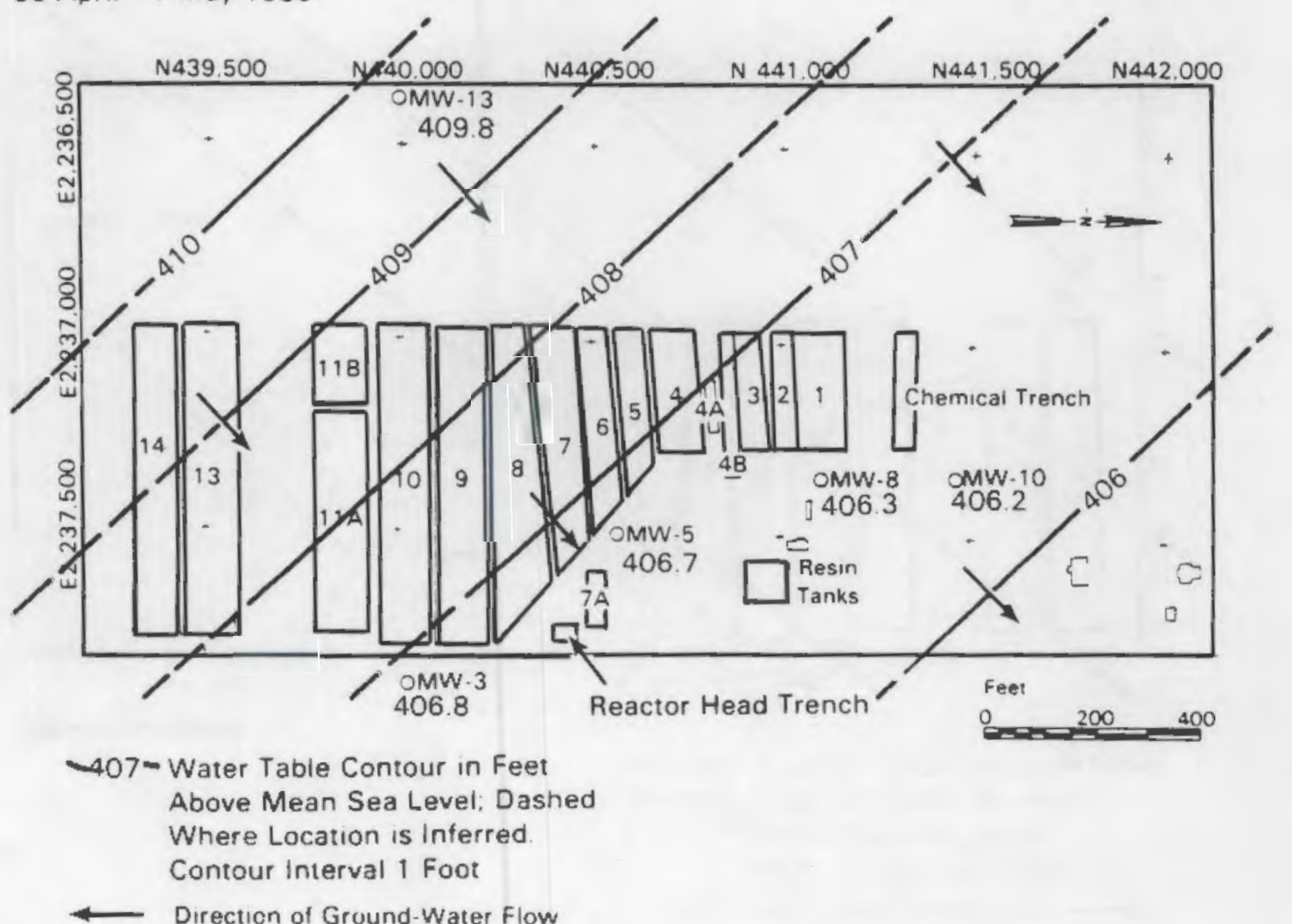

FIGURE 2.9. Water-Table Maps of the U.S. Ecology Site (from Bergerson, Last, and Reisenauer 1987) 
22 July - 23 July 1986

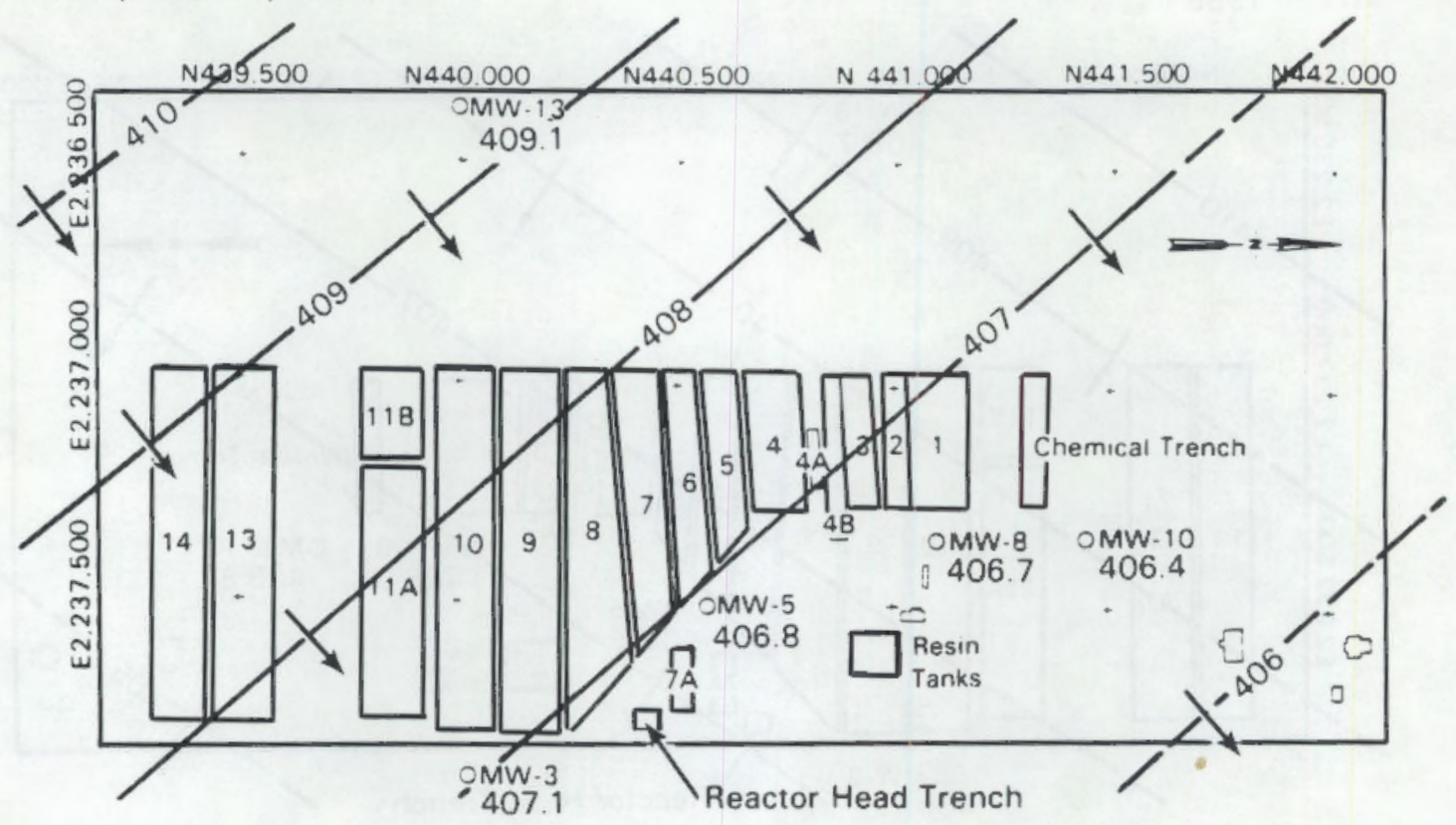

12 Nov - 13 Nov 1986

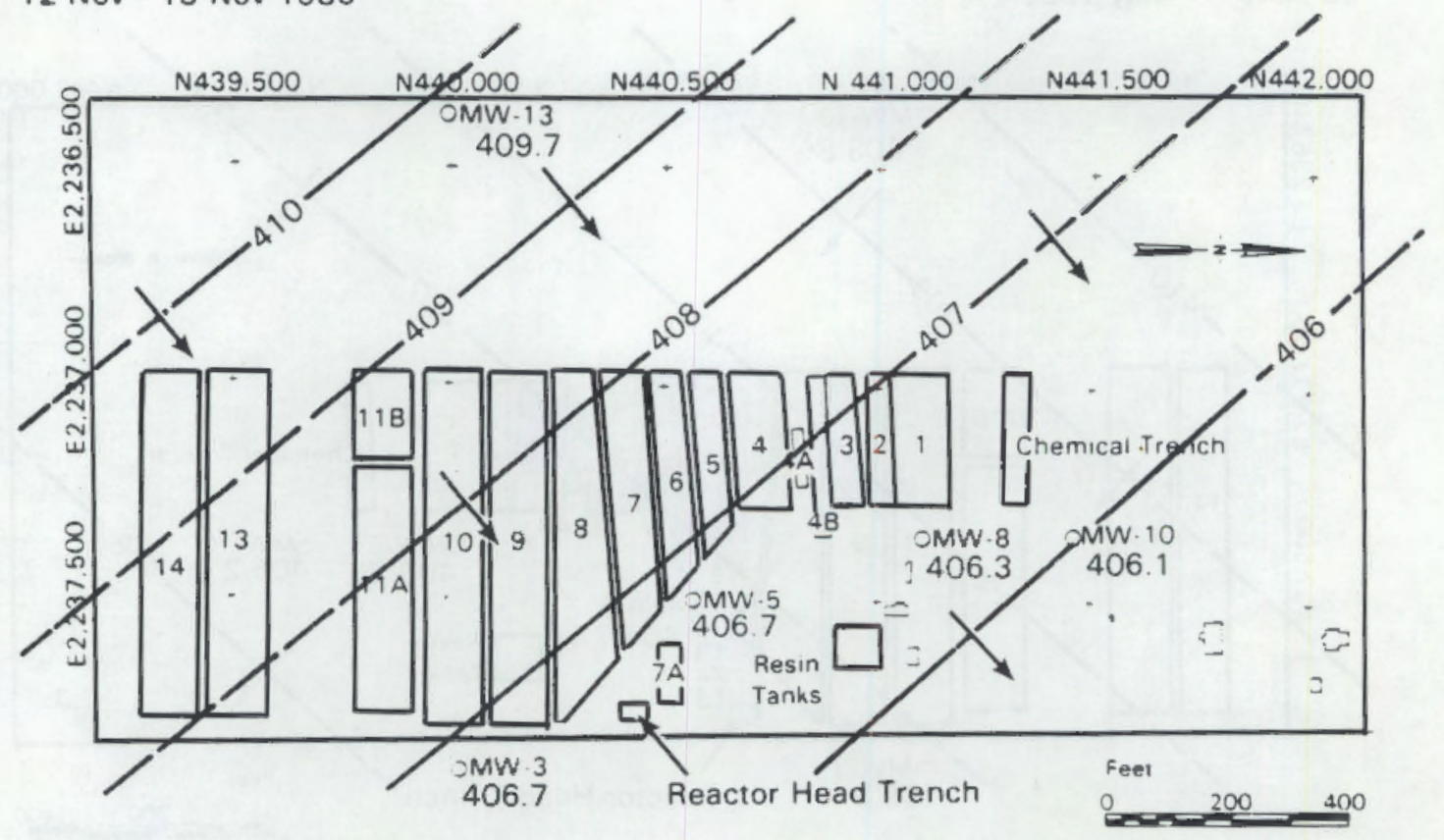

-407-Water Table Contour in Feet

Above Mean Sea Level; Dashed

Where Location is Inferred.

Contour Interval 1 Foot

$\longleftarrow$ Direction of Ground. Water Flow

FIGURE 2.9. (contd) 
The maximum increase in head that was predicted by the model beneath the area of recharge was approximately $0.0033 \mathrm{ft}$. This is clearly insignificant in terms of mounding and the potential for vertical ground-water flow.

\section{HISTORICAL GROUND-WATER DATA}

Historical ground-water data are available from three existing wells within $2000 \mathrm{ft}$ of the $2101-\mathrm{M}$ pond. A summary of the status of these wells is provided in Table 2.3, and their locations were shown in Figure 2.6. The geologic and as-built diagrams for the wells are provided in Appendix A.

\section{Water Levels}

Water-level data for two wells near the 2101-M pond are provided in Table 2.4. Many other wells are regularly monitored in the general vicinity and provide information on the depth to ground water and direction of groundwater flow (Schatz and Ammerman 1988).

IABLE 2.3. Status of Existing Wells in the Vicinity of the 2101-M Pond

\begin{tabular}{|c|c|c|}
\hline $\begin{array}{c}\text { We } 11 \text { Number } \\
\text { (Date Completed) }\end{array}$ & $\begin{array}{l}\text { Approximate } \\
\text { Distance and } \\
\text { Direction from } \\
\text { Site (ft) } \\
\end{array}$ & Well Status \\
\hline $\begin{array}{c}299-\text { E19-1 } \\
(12 / 57)\end{array}$ & 1600 WSW & $\begin{array}{l}\text { Constructed of } 8 \text { - and } 4-i n \text {. carbon } \\
\text { steel casing to depths of } 368 \text { and } \\
411 \mathrm{ft} \text {, respectively, with a } 3 \text {-in. } \\
\text { carbon steel liner to } 356 \mathrm{ft} \text { grouted } \\
\text { in place. Three-inch open hole to } \\
536 \mathrm{ft} \text { was filled with drilling mud } \\
\text { and is currently not usable for water } \\
\text { level measurements or samples. }\end{array}$ \\
\hline $\begin{array}{l}299-E 13-14 \\
(12 / 53)\end{array}$ & $1800 \mathrm{SW}$ & $\begin{array}{l}\text { Constructed of } 8 \text {-in. carbon steel } \\
\text { casing perforated from } 212 \text { to } 217 \mathrm{ft} \\
\text { below ground surface. }\end{array}$ \\
\hline $\begin{array}{c}299-E 23-2 \\
(5 / 65)\end{array}$ & $1700 \mathrm{NE}$ & $\begin{array}{l}\text { Constructed of } 8 \text {-in. carbon steel } \\
\text { casing perforated from } 320 \text { to } 340 \mathrm{ft} \\
\text { below ground surface. It has three } \\
\text { piezometers set at depths of } 340 \text {, } \\
400 \text {, and } 456 \mathrm{ft} \text {. Problems with the } \\
\text { piezometers have prevented sample } \\
\text { collection since October } 1987 \text {. }\end{array}$ \\
\hline
\end{tabular}


TABLE 2.4. Water-Level Elevation Data from Existing Wells Near the 2101-M Pond (a)

\begin{tabular}{|c|c|c|c|c|c|}
\hline Hell Number & $\begin{array}{l}\text { Top of } \\
\text { Casing } \\
\text { Elevation } \\
\end{array}$ & $\begin{array}{l}\text { Depth to } \\
\text { Water, } \\
\text { June } 1986 \\
\end{array}$ & $\begin{array}{c}\text { Water } \\
\text { Elevation, } \\
\text { June } 1986 \\
\end{array}$ & $\begin{array}{l}\text { Depth to } \\
\text { Water, } \\
\text { Dec. } 1986 \\
\end{array}$ & $\begin{array}{c}\text { Water } \\
\text { Elevation, } \\
\text { Dec. } 1986\end{array}$ \\
\hline $99-E 23-2$ & 721.26 & 315.17 & 406.09 & 315.27 & 405.99 \\
\hline $99-E 13-14$ & 745.37 & 339.12 & 406.25 & 339.55 & 405.82 \\
\hline
\end{tabular}

(a) All wells are completed in the unconfined aquifer. Measurements are al1 in feet above mean sea level.

Ground-Water Quality

Two of the wells nearest the 2101-M pond, 299-E23-2 and 299-E13-14, have been sampled regularly for a number of years for radiological constituents and nitrate. In 1985, the monitoring program at Hanford was expanded to include sampling of hazardous as well as radiological constituents at selected wells. In May 1987, well 299-E13-14 was added to this program. Appendix $B$ lists the constituents that are currently analyzed in the sitewide monitoring program and the analytical results for the ground water in we11s 299-E23-2 and 299-E13-14 for the period 1986 to April 1988. Expanded chemical analyses have been completed only on well 299-E13-14. No hazardous constituents sampled for at this well were present in concentrations greater than drinking water standards. However, the data collected from well 299-E23-2 show tritium present in concentrations greater than drinking water standards: 25,900 and 33,500 pCi/L on March 27, 1987, and June 29, 1987, respectively (see Appendix B). The 200-East Area tritium plume map (Serkowski et a). 1988) indicates the tritium plume extends beneath this well. It is not known whether the tritium plume extends beneath the 2101-M pond. 


\subsection{PHASE I. INDICATOR EVALUATION GROUND-WATER MONITORING PROGRAM}

\section{OBJECTIVES AND APPROACH}

This plan has been developed in accordance with RCRA as described in 40 CFR 265, Subpart F, and with WAC 173-303 (Ecology 1986) to establish an indicator evaluation ground-water monitoring program for the 2101-M pond, and, if necessary, to initiate an assessment-level program.

\section{Objectives}

The objectives of this plan for the 2101-M pond are to

- characterize the stratigraphy and the horizontal ground-water flow directions and rates beneath the pond (the focus will initially be on the uppermost portion of the unconfined aquifer)

- implement a monitoring program to determine if statistically significant amounts of hazardous waste constituents are detectable in the ground water

- initiate, if necessary, the development of an assessment-level monitoring program to determine the nature and extent of contaminant migration from the pond.

\section{Approach}

- The hydrogeologic characterization effort will be conducted in concert with the installation of the four planned ground-water monitoring wells, utilizing these wells to obtain hydrogeologic information for the site. The objective of this conjunctive effort is to both characterize the hydrogeology of the site and to provide a ground-water monitoring system as soon as possible. Recommendations will be made for further characterization or installation of additional ground-water monitoring wells, if deemed necessary.

As discussed in Chapter 2.0, the direction of ground-water flow beneath the $2101-M$ pond is estiniated to be from southwest to northeast. Four groundwater monitoring wells will be installed: one upgradient and three downgradient (planned locations are shown in Figure 3.1). The wells will be installed within the uppermost unconfined aquifer and screened at the water 


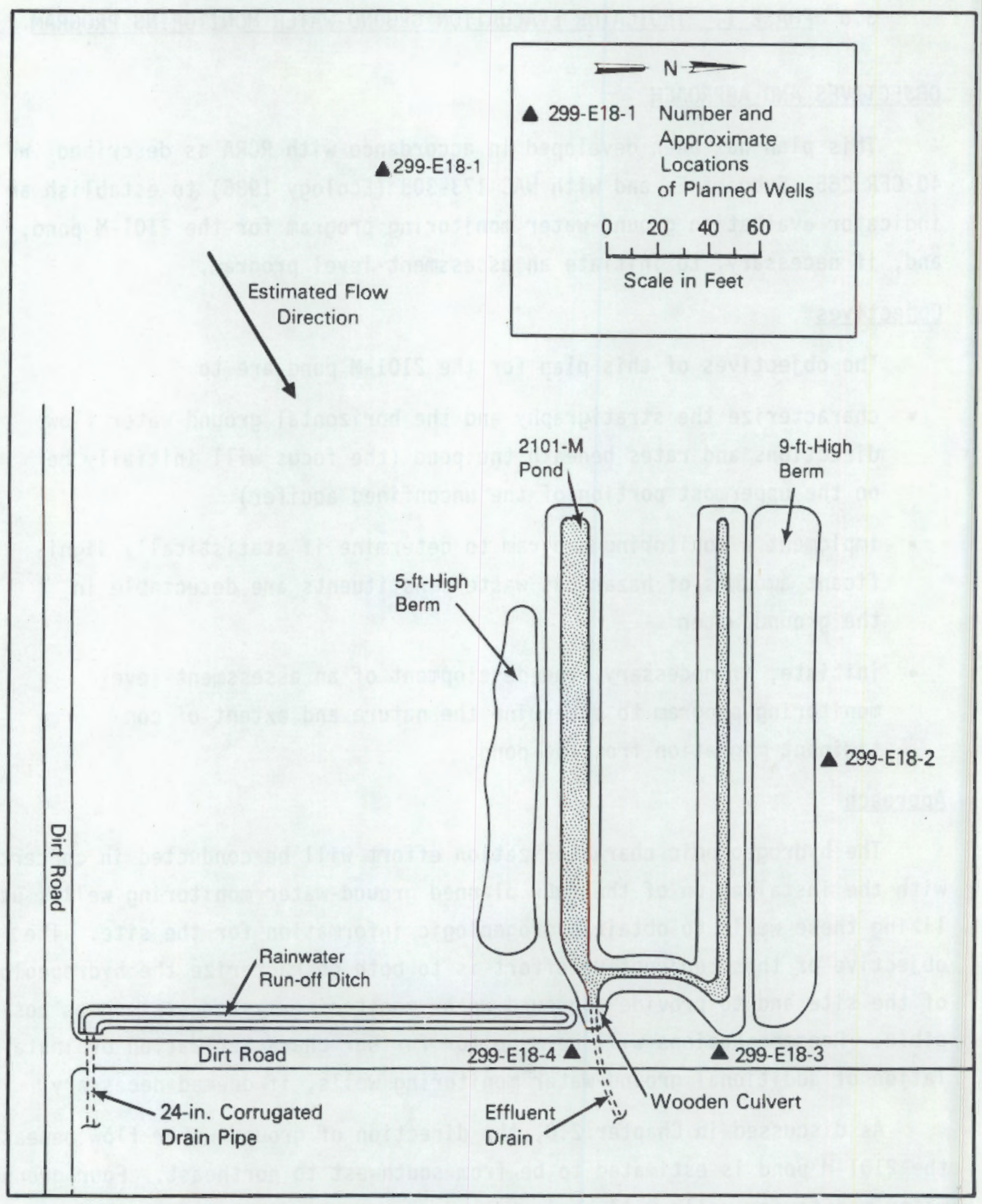

FIGURE 3.1. Locations of Planned Ground-Water Monitoring Wells 
table. These wells, along with any existing wells to be used, will provide information on stratigraphy, ground-water flow direction, and water quality of the upper portion of the unconfined aquifer. If the flow direction is determined to be different from that assumed here, other existing wells will be evaluated for use as background monitoring wells.

Subsurface soil samples will be obtained during drilling at each location. These samples will be classified in the field for later identification of stratigraphy, and selected samples will be submitted to the laboratory for testing of various physical parameters. Selected sediment samples may also be analyzed for hazardous constituents. Ground-water samples will be collected on reaching the final depth and analyzed for several constituents before aquifer testing or well development to determine whether the ground water can be discharged directly to the land surface. If these analyses indicate that the ground water exceeds $10 \%$ of the designated equivalent concentration limit (WAC 173-303-101, Ecology 1987) or any radioactive constituent exceeds $1 / 25$ of the Derived Concentration Guide (DCG) found in Appendix A, Environmental Protection Manual (Rockwell 1987), the ground water cannot be discharged directly to the ground. (a) If any of these constituents are near their respective limits, water samples will be collected during aquifer testing and analyzed. Aquifer tests will be conducted to provide estimates of transmissivity and hydraulic conductivity beneath the site.

Quarterly water quality samples will be collected for 1 year from all of the planned monitoring wells at the $2101-M$ pond. The first round of samples will be collected following installation and development of the last well within the monitoring network to allow sufficient time for the wells to chemically stabilize.

(a) From G. D. Carpenter, Manager, Westinghouse Hanford Company Environmental Assurance, to R. E. Gerton, DOE Acting Director, Environmental Protection and Quality Assurance Division, Interim Criteria and Standards for Waste Water Discharges from Ground-Water Aquifer Pump Tests, letter $\$ 8752412$, July $17,1987$. 


\section{INDICATOR EVALUATION MONITORING PROGRAM}

This section defines the aquifer that will be monitored, the location and justification of the monitoring wells, how the new wells will be installed, the frequency of the sampling, and the analyses to be performed. The subsections were formatted to provide information in a way that will facilitate writing future permit requests and closure documents.

\section{Uppermost Aquifer}

The uppermost aquifer beneath the 2101-M pond is the unconfined aquifer. The base of this aquifer can be either the uppermost basalt flow (Elephant Mountain Member) or, where present, the clay of the lower/upper basal Ringold Formation. Aquifer thickness is estimated to range from approximately 45 to $175 \mathrm{ft}$, depending on whether the lower/basal Ringold or basalt forms the base of the unconfined aquifer. Where it has not been eroded, the Elephant Mountain Member is typically dense, relatively impervious, and thick enough to prevent communication between the unconfined and deeper confined aquifers. The available geologic data for the Separations Areas (Tallman et a1. 1979) suggest that the forces that eroded the Ringold Formation and the Elephant Mountain Member north of the 200-East Area did not erode them beneath the $2101-M$ pond.

The best estimate of flow direction beneath the 2101-M pond indicates flow to the northeast. It is assumed that there is insignificant or no vertical flow component, as indicated in Chapter 2.0 .

\section{Background (Upgradient) Wells}

Based on the estimate of a northeasterly ground-water flow direction, background wells should be to the southwest of the pond. The closest existing upgradient we11, 299-E19-1, is located $1700 \mathrm{ft}$ away from the pond (see Figure 2.6). However, this well is currently partially filled with drilling mud, and is not open to the uppermost aquifer. Appendix A provides the best evaluation of this well's construction. A new well, to be located approximately $200 \mathrm{ft}$ southwest of the southwestern corner of the pond, is $\mathrm{planned}$ for this project (see Figure 3.1). It will be drilled to a depth of approximately $335 \mathrm{ft}$ and will monitor the upper $18 \mathrm{ft}$ of the unconfined aquifer. 


\section{Detection (Downgradient) Wells}

Three new downgradient we11s are planned north, northeast, and southeast of the pond (see Figure 3.1). These wells will be drilled approximately $50 \mathrm{ft}$ away from the edge of the pond to a depth of approximately $335 \mathrm{ft}$ and will monitor the upper $18 \mathrm{ft}$ of the unconfined aquifer.

\section{Use of Existing Wells}

Existing wells in the vicinity of the 2101-M pond may be used for waterlevel measurements and/or evaluation of the unconfined aquifer ground-water quality. Before being used as background wells for ground-water quality, existing wells will be evaluated following the criteria discussed below. If the wells cannot be used as monitoring wells, they may still be used for water-level measurements, as will well 299-E23-2.

\section{Evaluation Plan}

Nearby wells will be evaluated, considering proximity to the pond, open intervals, reliable elevations, and ease of access, before being used for obtaining water-level measurements. The following criteria should be met before wells are used as background monitoring wells: 1) proximity to the pond, 2) is the integrity of the well suitable for its use as a monitoring wel1, 3) is the quality of the water-chemistry data comparable to that of the new wells, and 4) is the well truly upgradient or downgradient. Well 299-E23-2 will not be used as a downgradient well because of its distance (1800 ft) from the pond and the tritium contamination already present in it from other sources (see Chapter 2.0 and Appendix B).

\section{Installation of New Characterization/Monitoring Wells}

Four new wells will be installed for this project. Their approximate locations are shown in Figure 3.1. The purpose of these wells is ultimately to: 1) provide hydraulic head data to help determine the ground-water flow direction beneath the site, 2) provide up- and downgradient ground-water quality information from the upper portion of the unconfined aquifer, 3 ) evaluate the hydraulic properties of the upper part of the aquifer, 4) define the subsurface stratigraphy beneath the site, and 5) determine the 
moisture content of the unsaturated zone. The wells will be located to provide one monitoring well upgradient and three monitoring wells downgradient of the pond (see Figure 3.1).

\section{Justification for Locations}

As stated earlier in Chapter 2.0, ground-water flow in the southwestern corner of the 200-East Area is estimated to be to the northeast. Therefore, the new background well will be located approximately $200 \mathrm{ft}$ southwest of the southwestern corner of the 2101-M pond (see Figure 3.1). This should provide sufficient distance from the pond to be unaffected by discharges to the pond and provide representative information on the ground-water quality upgradient of the pond.

The three downgradient wells will be located within $50 \mathrm{ft}$ of the edge of the pond, on the southeastern and northeastern corners and halfway down the north side (see Figure 3.1). The locations were chosen to ensure the best probability of all three wells being downgradient of the pond, given the assumed flow direction in that area. The wells are close enough to the pond to monitor any contaminants in the ground water originating from the pond. Contaminants may move horizontally in the vadose zone if percolating water encounters a fine-grained sedimentary layer and moves laterally; however, little lateral movement of water or contaminants in the vadose zone is expected at the 2101-M pond based on the relatively small discharge rate to the pond.

All four wells will be installed in the upper portion of the unconfined aquifer. The total depth of each of the boreholes will be approximately $18 \mathrm{ft}$ below the water table. Twenty-foot-long stainless steel screens will be set $18 \mathrm{ft}$ into the water table to ensure sampling of the top of the unconfined aquifer and to allow $2 \mathrm{ft}$ of screen above the water table in case of future water-level increases. The estimated depth of the water table beneath the $2101-M$ pond is $315 \mathrm{ft}$. 


\section{Drilling and Well Installation}

Detailed information on the functional design and construction standards for the monitoring wells to be installed is given in Appendix C. The following discussion provides general information not covered in Appendix C.

The wells will be drilled by the cable-tool method. Cable-tool drilling is desirable because 1) drill cuttings are easily contained (important in contaminated material), 2) representative geologic samples can be collected, 3) moisture samples can be collected from above the water table using corebarrel techniques, 4) disturbance to the borehole wall is minimized, 5) a straight and plumb borehole is produced, and 6) no drilling additives other than water need to be added. Generally, only the hard-tool method of drilling with a cable-tool rig requires water, and only water from an approved source (generally raw water from the Columbia River) will be allowed.

Perched water may be encountered in the wells closest to the pond during drilling if very fine-grained sediments are present in the vadose zone. Perched water will be sealed off as described in Appendix C. This will isolate the potentially contaminated zone and allow continued drilling of the borehole. If contamination is visible or has been detected with an OVA, HNU, or a radiation monitoring instrument during drilling above the perched zone, the borehole will be advanced only after sealing off the contaminated zone. This technique should minimize the possibility of spreading the contamination to the unconfined aquifer. If a perched water table is encountered in the vadose zone, an evaluation will be made as to whether a well should be installed to monitor it.

Temporary carbon steel casing will be driven the total depth of the we11. After reaching the desired depth, installing the 8-in. telescoping screen, and developing the well, ground-water samples will be taken. The following ground-water contamination indicator parameters will be analyzed for as soon as possible after sampling: 1) volatile organic constituents, 2) metals analyzed by the inductively coupled plasma method, 3) gamma scan, 4) gross alpha, and 5) gross beta; one well will be analyzed for iodine-129. If concentrations of these constituents exceed the levels stated in the Effluent Monitoring Plan for the 2101-M pond, which will be written before 
aquifer testing begins, no tests will be conducted unless proper treatment and disposal of the pumped water are available. A discussion of the planned aquifer tests is given later in the section on hydrogeologic characterization.

At the completion of aquifer testing, the telescoping well screen will be left in the hole. The nominal inside diameter of the temporary casing and/or telescoping screen at the bottom of the borehole will be 8 in., allowing a 4-in.-dia. monitoring well to be installed with an adequate annular seal.

A schematic diagram of a completed well is presented in Figure 3.2. Final wells will be constructed of 4 -in. inside diameter, 304 or 316 stainless steel casing and a continuous-slot stainless steel well screen. Final well screen lengths will be $20 \mathrm{ft}$, with approximately $2 \mathrm{ft}$ of screen extending above the water table to allow for possible future fluctuations of the unconfined aquifer. This will also ensure that samples are from the upper portion of the aquifer and allow detection of any immiscible constituents that might be floating on the surface of the water. The slot size for the permanent screen will be determined by laboratory analysis of grain-size distribution or, if time is short, by the well site geologist following procedures given in Last and Liikala (1987).

The annular seal will be emplaced using materials as specified in Appendix $C$ while pulling back the temporary carbon steel casing. Figure 3.2 shows the general thicknesses and position of each of the different types of materials to be used for the annular seal. The materials and methods of installation meet the WAC 173-160 (Ecology 1988) requirements for resource protection wells.

The 4-in. well casing will extend approximately $1 \mathrm{ft}$ above ground surface. To protect the 4-in. well and provide shelter for data loggers, a piece of 6 -in. stainless steel casing will be set into the concrete pad. A drain hole will be drilled approximately $1 / 2$-in. above the concrete pad for drainage of water from inside the protective casing. The protective casing will also be vented. This protective casing will be permanently marked with well identification numbers. This information will also be stamped on a 


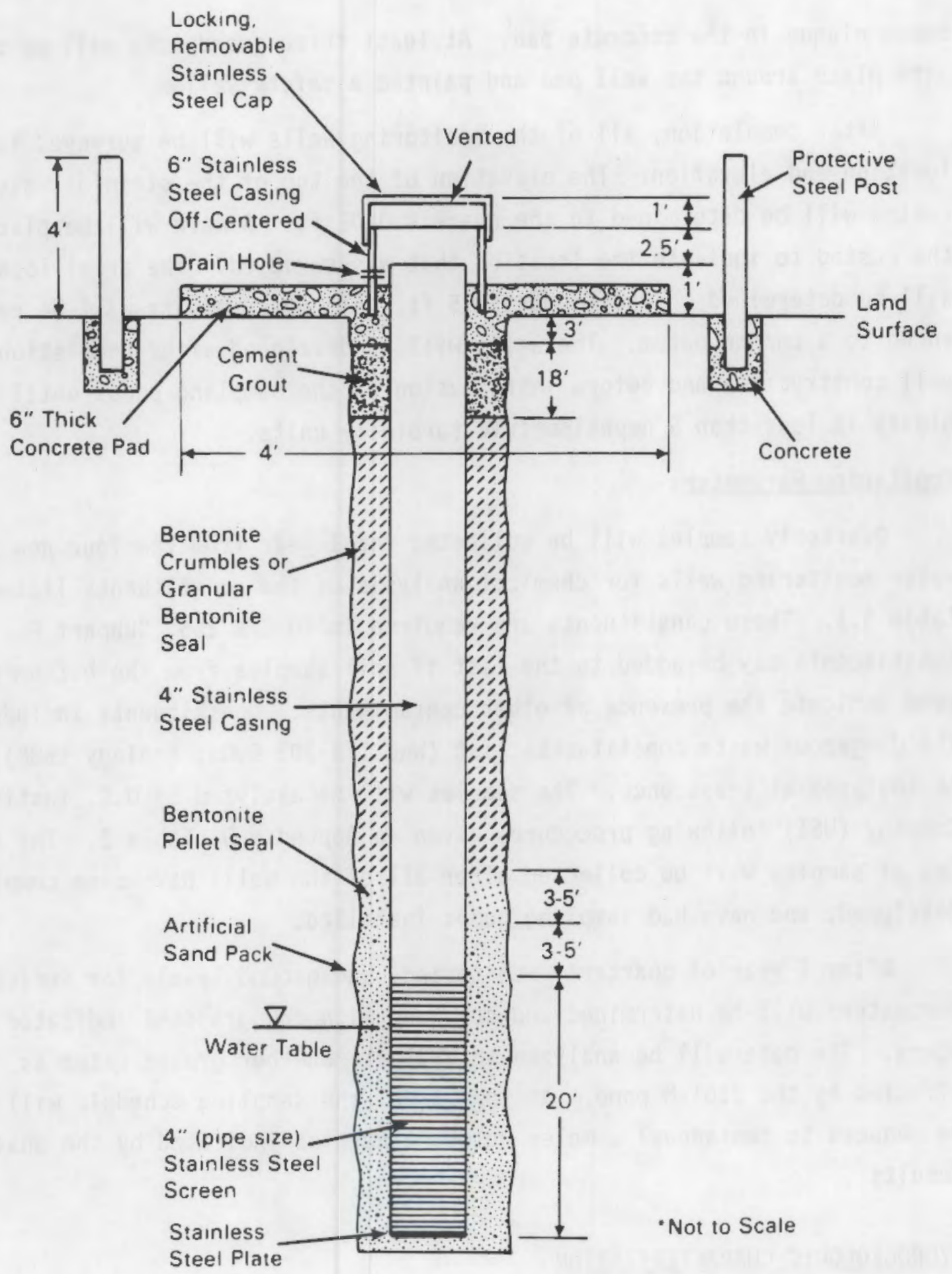

FIGURE 3.2. Schematic Diagram of a Completed Ground-Water Monitoring Well (not to scale) 
brass plaque in the concrete pad. At least three guardposts will be cemented into place around the well pad and painted a safety yellow.

After completion, all of the monitoring wells will be surveyed for location and elevation. The elevation of the top of the stainless steel casing will be determined to the nearest $0.02 \mathrm{ft}$. A mark will be placed on the casing to indicate the location that was surveyed. The areal location will be determined to the nearest $0.5 \mathrm{ft}$. All measurements will be referenced to a common datum. The wells will be developed after completion of well construction and before installation of the sampling pumps until turbidity is less than 5 nephelometric turbidity units.

\section{Monitoring Parameters}

Quarterly samples will be collected for 1 year from the four new groundwater monitoring wells for chemical analysis of the constituents 1 isted in Table 3.1. These constituents are required in 40 CFR 265, Subpart F. Other constituents may be added to the list if soil samples from the bottom of the pond indicate the presence of other contaminants. Constituents included in the dangerous waste constituents list (WAC 173-303-9905; Ecology 1986) wil1 be analyzed at least once. The samples will be analyzed by U.S. Testing Company (UST) following procedures given in Appendix D, Table 2. The first set of samples will be collected after all of the wells have been completed, developed, and have had sampling pumps installed.

After 1 year of quarterly monitoring, background levels for indicator parameters will be determined and compared with downgradient indicator parameters. The data will be analyzed to evaluate whether ground water is affected by the 2101-M pond. At that time, the sampling schedule will also be reduced to semiannual samples unless otherwise indicated by the analytical results.

\section{HYDROGEOLOGIC CHARACTERIZATION}

This section discusses the types of samples to be collected and analyses that will be performed during and after well installation. These data will then be used to perform the geologic and hydrologic characterizations. Work 
TABLE 3.1. Ground-Water Sampling Parameters(a)

\begin{tabular}{lc} 
Interim Primary Drinking Water Standards & Maximum Leve] (b) \\
\hline Arsenic & 0.05 \\
Barium & 1.0 \\
Cadmium & 0.01 \\
Chromium & 0.05 \\
Fluoride & 1.4 to 2.4 \\
Lead & 0.05 \\
Mercury & 0.002 \\
Nitrate (as N) & 10 \\
Selenium & 0.01 \\
Silver & 0.05 \\
Endrin & 0.0002 \\
Lindane & 0.004 \\
Methoxychlor & 0.1 \\
Toxaphene & 0.005 \\
2,4-D & 0.1 \\
2,4,5-TP Silvex & 0.01 \\
Radium & $5(\mathrm{pCi} / \mathrm{L})$ \\
Gross a7pha & $15(\mathrm{pCi} / \mathrm{L})$ \\
Gross beta & $4(\mathrm{mi} 1 \mathrm{irem} / \mathrm{yr})$ \\
Turbidity (surface water only) & 1 (TU) \\
Coliform bacteria & $1 / 100(\mathrm{~mL})$
\end{tabular}

Ground-Water Quality Parameters

Chloride

Iron

Manganese

Phenots

Sodium

Sulfate

Ground-Water Contamination Indicator Parameters

$\mathrm{pH}$

Specific conductance

Total organic carbon

Total organic halogen

(a) From 40 CFR 265, Subpart F. Regulatory requirements for sampling parameters are subject to change because of federal regulations.

(b) Concentrations are in $\mathrm{mg} / \mathrm{L}$ unless otherwise noted. 
will be conducted following established procedures. Some of these procedures are provided in Appendix $D$ of this report or in Last and Liikala (1987). The Pacific Northwest Laboratory (PNL) Quality Assurance Plan for the 2101-M project is provided in Appendix E.

Geologic Characterization

Data will be collected during drilling of the monitoring wells for use in characterizing the geology and stratigraphy of the area around the 2101-M pond. Types of data to be collected are discussed below.

\section{Geologic Sampling}

Geologic samples will be collected during drilling at 5 -ft intervals or at changes in 1ithology. Samples will be collected with a drive barrel in the unsaturated sediments whenever possible. If hard-tool drilling is necessary, a bailer will be used to collect the sediment samples. No drilling water or other material will be added to the borehole during drive-barrel drilling unless necessary and approved by the well site geologist so that perched water zones can be detected and representative moisture samples can be taken. Moisture samples will be collected in the unsaturated sediments at 5-ft intervals and at unusually moist or wet zones.

The samples collected will be described as hand specimens in the field and documented on geologic field forms. A guide to subsurface data collection and documentation during cable-tool drilling is presented in Last and Lijkala (1987).

\section{Sample Analyses}

Selected samples will be collected for laboratory analyses, which will include 1) particle size, 2) moisture content, 3) calcium carbonate content, 4) saturated hydraulic conductivity, 5) water retention, 6) petrographic description of mineral content, and, possibly, 7) chemical analyses for hazardous constituents. The first three analyses will be run on all of the samples in the vadose zone, and sieve analysis may be run on the samples from the saturated zone as well. At least one representative sample will be collected for the second three analyses from each major stratigraphic unit encountered during drilling. If perched water is encountered during 
drilling, sediment samples as well as water samples may be taken for analysis of possible hazardous constituents. The latter analyses witi be performed by UST following procedures given in SW-846 (EPA 1982) when possible.

\section{Borehole Logging}

Each well will be geophysically logged with natural gamma, density, and neutron probes on reaching the final depth and before completion of the well.

\section{Data Interpretation and Presentation}

All geologic and geophysical data will be interpreted by geologists to establish the stratigraphy beneath the site. These data will be presented in cross sections, fence diagrams, and tables, using the technical enforcement guidance document (EPA 1986) as guidance. Interpretations of the stratigraphy will be used in evaluating potential contaminant flow paths through the vadose zone and in determining the hydrostratigraphic units beneath the pond.

The data, interpretations, and recommendations will be presented in an interim site characterization report tentatively scheduled for completion in early 1990. The report will include 1) descriptions of stratigraphic units, 2) results of analyses, 3) as-built diagrams of wel1s, and 4) recommendations for further characterization or additional monitoring wells, if necessary. Appendixes may include data, such as the moisture content and grain-size distribution data, and geophysical logs.

\section{Hydrologic Characterization}

Data will be collected during and after drilling of the monitoring wells and $w i l l$ be used in characterizing the hydrogeology of the area around the 2101-M pond. The types and methods of data collection are discussed in detail below.

\section{Aquifer Testing}

The test plan outlined below is intended to provide preliminary, semiquantitative hydraulic conductivity values from tests conducted during monitoring wel1 construction. It is important to perform aquifer tests at the 2101-M pond site because it is uncertain what formation(s) the unconfined aquifer occurs in or what the site-specific aquifer properties are. 
Transmissivity values have been determined from aquifer tests conducted some distance from the 210I-M pond. At wel1 299-E28-15, located approximately 1 mile north of the $2101-M$ pond, the transmissivity was determined to be approximately $140,000 \mathrm{ft}^{2} / \mathrm{d}$; however, insufficient stress was imposed to obtain a quantitative value. At well 699-33-56, located approximately 1 mile south of the pond, the transmissivity was determined to be approximately $21,000 \mathrm{ft} 2 / \mathrm{d}$. Transmissivity beneath the $2101-M$ pond may be closer to, or even greater than, the higher value based on the nearly horizontal water table and data from other aquifer tests in the 200-East Area.

Assumptions of aquifer properties used to predict drawdowns in the pumping and observation wells are transmissivity ranging from 20,000 to $200,000 \mathrm{ft}^{2} / \mathrm{d}$ and storativity of 0.05 . The values for transmissivity range from a conservative estimate based on data from aquifer tests in the 200-East Area to approximately the value determined at well 699-33-56. Storativity is from documented data on the Hanford Site (Graham et al. 1981). Drawdowns, based on the above storativity and transmissivity va7ues, are given below for distances of $100 \mathrm{ft}$ (observation wel1) and $1 \mathrm{ft}$ (pumping we11) at discharge rates of 150 and $300 \mathrm{gpm}$ and a time of 0.2 day. These discharge rates are assumed because the well construction design will allow placement of a pump capable of yielding up to $300 \mathrm{gpm}$.

The drawdowns predicted in Table 3.2 indicate that at a transmissivity of $200,000 \mathrm{ft}^{2} / \mathrm{d}$, a pumping rate of $150 \mathrm{gpm}$ will provide very sma 11 drawdowns and thus could provide only qualitative estimates of transmissivity. A rate of $300 \mathrm{gpm}$ will provide larger drawdowns by stressing the aquifer more, thereby allowing more representative estimates of transmissivity from analyses of both observation and pumping well data. Two options are currently

TABLE 3.2. Predicted Drawdowns

\begin{tabular}{|c|c|c|c|c|}
\hline \multirow{3}{*}{ Pumping Rate } & \multirow{2}{*}{\multicolumn{2}{|c|}{$\frac{\text { Iransmissivity: } 200,000 \mathrm{ft}^{2} / \mathrm{d}}{\text { Distance }}$}} & \multirow{2}{*}{\multicolumn{2}{|c|}{$\frac{\text { Transmissivity: } 20,000 \mathrm{ft}^{2}}{\text { Distance }}$}} \\
\hline & & & & \\
\hline & $100 \mathrm{ft}$ & $1 \mathrm{ft}$ & $100 \mathrm{ft}$ & $1 \mathrm{ft}$ \\
\hline $150 \mathrm{gpm}$ & $0.06 \mathrm{ft}$ & $0.16 \mathrm{ft}$ & $0.34 \mathrm{ft}$ & $1.39 \mathrm{ft}$ \\
\hline $300 \mathrm{gpm}$ & $0.12 \mathrm{ft}$ & $0.33 \mathrm{ft}$ & $0.67 \mathrm{ft}$ & $2.78 \mathrm{ft}$ \\
\hline
\end{tabular}


available for providing a minimum pumping rate of $300 \mathrm{gpm}$. One option is to install a 40-hp pump capable of fitting within the nominal 8-in. telescoping screen for use in the aquifer tests. This will allow pumping rates of at least $300 \mathrm{gpm}$. Another option is to drill the well somewhat deeper than planned, place the temporary screen at the bottom of the hole, and set a 40-hp pump immediately above the screen. Either of these options will allow collection of semiquantitative information on the hydraulic conductivities in this area where no data exist.

Two tests are planned: one will be conducted at well 299-E18-3 and another at well 299-E18-1 (see Figure 3.1). The test at well 299-El8-3 will use the two nearby monitoring wells as observation wells, if they have screens in them by the time of the test. Probably none of the new monitoring wells will be close enough for use as an observation well during the aquifer test at we11 299-E18-1. The wells will be drilled with 8-in.-dia. drive casing, and 8-in. telescoping screens will be placed in the uppermost part of the aquifer. A discharge rate of approximately $300 \mathrm{gpm}$ should be attained. The test duration will be from 2 to $8 \mathrm{~h}$, depending on the discharge rate and an initial analysis of drawdown data in the field. Drawdown and recovery data will be collected using transducers and electric tapes in the pumping well and available observation wells. The data will be analyzed using modified Theis methods.

As previously discussed, ground-water samples will be collected and analyzed for several constituents before aquifer testing or well development to determine whether the ground water can be discharged directly to the land surface. If these analyses indicate that any hazardous constituent exceeds $10 \%$ of an equivalent concentration or any radioactive constituent exceeds $1 / 25$ of the DCG, the ground water cannot be discharged directly to the ground. If any of these constituents are near their respective limits, water samples will be collected during aquifer testing and anajyzed.

\section{Determination of Ground-Water Flow Paths}

Water levels will be measured in the four monitoring wells as well as in several existing wells around the southeastern portion of the 200-East Area to calculate the elevation and configuration of the water table. The degree 
of uncertainty associated with water-level measurements will be evaluated, and the ground-water flow direction will be calculated.

When possible, the water level of each monitoring well will be measured with a steel tape or electric tape whenever ground-water samples are taken, and more often if deemed necessary. Difficulties occasionaliy arise that prevent measurement of the water levels in some wells before sampling or that result in poor measurements. Consequently, these instances will be evaluated on a case-by-case basis and accepted as satisfactory if water levels have recently been collected and/or have been measured at one of the other monitoring wells and no large water-level fluctuations have been observed. If they are not satisfactory, water levels will be measured in those wells as soon as possible. Factors that will be considered in determining the frequency of measurements include observed water-lever trends in these and other wells in the Separations Areas, degree of uncertainty in the determination of ground-water flow direction, and variability and trends in liquid discharges to ground in the Separations Areas. The surface of the water table and the direction of ground-water flow will be determined annually as required by 40 CFR 265.93 .

\section{Data Interpretation and Presentation}

The hydrogeologic data interpretation was discussed in part above. The results of these data will be integrated to form a preliminary conceptua] model of ground-water flow. Components of the model will include the determination and description of hydrostratigraphic units, a description of ground-water flow paths, estimates of ground-water velocity, estimates of vadose zone conditions as they relate to the ground-water monitoring system, and hydrochemical characterization.

The data will also be used to evaluate whether the characterization effort was adequate or whether the ground-water monitoring system is appropriately designed. Recommendations will be provided for additional characterization activities or monitoring wells, if necessary.

The data, interpretations, and recommendations will be presented in an interim characterization report tentatively scheduled for completion in early 1990. The report will include 1) descriptions of hydrostratigraphic units, 
2) water-level data and water-table maps, 3) test data and results of analyses, 4) hydrochemistry data, and 5) recommendations for further characterization or additional monitoring wells, if necessary.

\section{SCHEDULE OF CHARACTERIZATION AND WELL INSTALLATION}

It is anticipated that the drilling of the monitoring wells will begin in June 1988. The rate of completion of individual wells has been estimated based on past drilling operations at the Hanford Site. The resulting time schedule (Figure 3.3) is representative of those estimates.

The assumptions used in developing the schedule estimate are as follows:

- sufficient drilling equipment will be available for the entire effort

- cable-tool drilling will be used to drill all of the wells

- the cable-tool drilling rate is $30 \mathrm{ft} / \mathrm{d}$

- the rate for pulling out the temporary casing from a cable-tool hole is $50 \mathrm{ft} / \mathrm{d}$
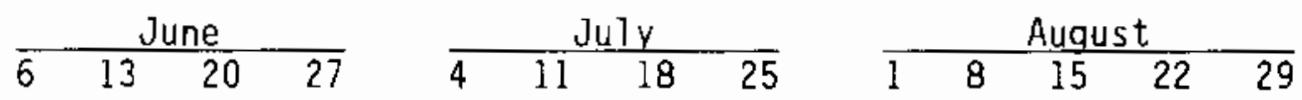

Well No.

299-E18-1

$299-E I 8-2$

$299-\mathrm{E} 18-3$

$299-E 18-4$

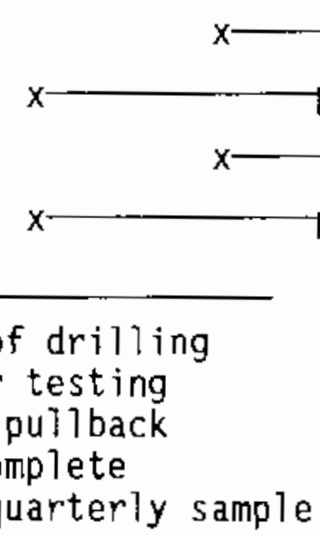

$x=$ start of drilling

$t=$ aquifer testing

$p=$ casing pullback

$\mathrm{C}=$ well complete

$s=$ first quarterly sample

FIGURE 3.3. Approximate Schedule for Installation of Monitoring Wells at the 2101-M Pond 
- the average work week is $8 \mathrm{~h} / \mathrm{d}, 5 \mathrm{~d} / \mathrm{wk}$

- at least two cable-tool drill rigs will be available to drill at the 2101-M pond.

\section{SAMPLING AND ANALYSIS}

Each well will be equipped with a dedicated HydroStar (a) pump, capable of pumping 3 to $5 \mathrm{gpm}$. These pumps do not aerate the water and, therefore, do not strip volatile organic constituents from the sample. Ground-water sampling will be conducted by trained personnel from PNL following procedures given in Appendix D. Sample preservation techniques are also provided in Appendix D. The samples will be delivered to UST for analysis following chain-of-custody procedures. Analyses at UST are performed following the procedures as listed by constituent in Appendix 0 . The results of the anaiyses are entered into PNL's Hanford Ground-Water Data Base.

\section{STATISTICAL ANALYSIS DF INDICATOR EVALUATION MONITORING DATA}

Data acquired through ground-water sample analyses will be evaluated statistically to determine whether discharges to the 2101-M pond have or are affecting the ground water. This section describes how and where the data will be evaluated and presented.

\section{Method}

After 1 year of quarterly monitoring, background levels for indicator parameters will be determined and compared with indicator parameters from downgradient wells. The data witl be analyzed to evaluate whether ground water is affected by the 2101-M pond.

\section{Establishing Background}

The approach used for establishing background values will involve quarterly sampling of the upgradient well for 1 year and semiannual sampling thereafter. During each quarterly sampling period, four samples will be

(a) The Hydrostar sampling pump is a trade name of Instrumentation Northwest, Inc., Redmond, Washington. 
obtained from the upgradient well for laboratory analysis of the indicator parameters, total organic carbon and total organic halogen, and four measurements of the field indicator parameters, $\mathrm{pH}$ and specific conductance, will be made.

Background summary statistics (mean, variance, and coefficient of variation) will be calculated from four quarters of data. The actual method that will be used for calculating summary statistics will depend on the distribution of the data and the presence of any data that are reported as less than the limit of detection. Replicate summary statistics will be calculated each quarter. Background comparison summary statistics will be calculated from the four sets of quarterly summary statistics.

\section{Evaluation of Data}

Wells will be sampled at least twice each succeeding year after background concentrations have been established. A minimum of four replicate measurements will be obtained from each well in the monitoring system for the indicator parameters, and the arithmetic mean and variance will be calculated for the indicator parameters for each sample.

The Student's t-test will be used to determine statistically significant changes in the concentration of indicator parameters of each well as compared to initial background concentrations or values. This comparison will consider individually each of the wells in the monitoring system. For three of the indicator parameters (specific conductance, total organic carbon, and total organic halogen), a single-tailed Student's t-test will be used to test at the 0.01 level of significance for significant increases over background. The difference test for pH will be a two-tailed Student's t-test at the overal1 0.01 level of significance. 
$\underline{\text { REPORTS }}$

A summary of the reports required by 40 CFR 265 , Subpart F, is given in Table 3.3 .

TABLE 3.3. Reports Required by 40 CFR 265, Subpart F, for Indicator Evaluation Ground-Water Monitoring

Submittal

First year of sampling:

concentrations of interim primary drinking water constituents, identifying those that exceed the limits Tisted in Table 3.1

Concentration and statistical analyses of ground-water contamination indicator parameters, noting significant differences in upgradient wells

Results of ground-water surface elevations and description of response if appropriate
Submittal Period

Quarterly reports according to the current schedute

Annualiy, according to the current schedule

Annually, according to the current schedule 


\subsection{PHASE II. INITIATION OF ASSESSMENT-LEVEL MONITORING PROGRAM}

This chapter discusses the development of criteria that would trigger notification of regutatory agencies and initiate an assessment-level monitoring program. The notifications required by $40 \mathrm{CFR} 265$, Subpart $F$, are presented, and the plan for the assessment-level monitoring program is outlined.

\section{INITIATION CRITERIA}

As indicated in Chapter 3.0, ground-water samples from all monitoring we11s will be tested quarterly for the first year for interim primary drinking water constituents, ground-water quality parameters, ground-water contamination indicator parameters, and any site-specific parameters (see Table 3.1).

Significant changes in the water quality of either the upgradient or downgradient wells must be reported. If significant changes are noted in the water quality of the downgradient wells, those wells must be immediately resampled, and the samples split in two and analyzed by independent laboratories to determine if the results were caused by laboratory error. If this second sampling also shows a significant increase (or $\mathrm{pH}$ decrease), the U.S. Environmental Protection Agency (EPA) and the Washington State Department of Ecology (hereafter called Ecology) must be notified in writing within 7 days of confirmation that the 2101-M pond might be affecting ground-water quality. If confirmed, the results of this second set of data trigger the development of a ground-water assessment plan, as discussed later in this chapter.

Ground-water surface elevation data will be collected semiannually and evaluated at least annually to determine if the existing monitoring wells are appropriately located. If the evaluation indicates that existing wells are no longer adequately located, the ground-water monitoring system will be modified to bring it into compliance with 40 CFR 265.91(a). 


\section{ASSESSMENT-LEVEL MONITORING PROGRAM}

An assessment-level ground-water monitoring program will be implemented when a release of hazardous constituents is indicated in the indicator evaluation monitoring program. The decision to implement the assessmentlevel program wi11 be based on criteria described in Chapter 3.0. The assessment-level ground-water monitoring plan will be certified by a qualified hydrogeologist or geotechnical engineer. This plan will address the following:

1. The strategy for assessing the site and ground water by instatling more wells--Ground-water monitoring wells may be drilled, as necessary, to determine the nature and extent of contamination. The number, location, and depth of each well will be identified with information on the design and construction of these wells.

2. Ground-water samples to be collected and analyzed, at a minimum, for constituents out 7 ined in 40 CFR 261, Appendix VIII, or Appendix IX when it is finatized.

3. Detailed procedures describing how the analytical results witl be evaluated, including the analysis of any previously gathered ground-water quality information.

4. A schedule for implementation of the assessment-level ground-water monitoring program.

A sample outline of an assessment-level monitoring plan is shown in Table 4.1. The following provides additional explanation for several items that will be addressed in the plan.

At sites where contaminants are known to have entered the ground water, the regulations specified in 40 CFR 265.93(d)(4) require that the rate and extent of contaminant movement be determined. The methods used to determine these will depend on the quantity and quality of the field data base. Methods will include additional monitoring well installations and field testing, ground-water flow and contaminant transport modeling, continued chemical analyses of selected constituents in existing and new well installations, and statistical evaluation of chemical analyses. 
TABLE 4.1. Sample Assessment-Leve Monitoring Plan Out7ine

Introduction

Background Information

Facility Description

Geology and Hydrology of the Site

Geology

Hydrology

Interim-Status Work Conducted to Date

Scope and Description

Well Network

Sample Collection

Water-Level Measurements

Sample Analysis

Data Handling and Verification

Analytical Data Evaluation

Quality Assurance

Results

Quality Control (QC)

Sampling Schedule

Constituent Lists

Constituents Detected

Constituent Concentrations

Graphs of the Data

Genera] Dbservations

QC Program Results

Factors Potentially Affecting the Data

Planned Expansion of Ground-Water Monitoring Program

Planned Approach

Evaluation of Existing Data

Installation of New Monitoring Wells

Collection and Analysis of Geologic Data

Collection and Analysis of Water Quality Data

Hydrologic and Water Quality Interpretation

Method of Determining Rate and Extent of Contaminant Movement

Schedule of Implementation

Reports to Be Produced

References

Appendixes 


\section{Nature and Extent of Contamination}

Analytical data from new and existing wells will be evaluated to determine the specific hazardous and nonhazardous constituents and levels of these constituents found in the ground water. In addition, the hazardous constituents will be statistically evaluated to determine which of these exceed background concentrations at the site. The data will be further evaluated to determine if particular constituents came from the 2101-M pond or originated from some other waste management facility.

The lateral extent of contamination will be estimated by contouring concentrations of various hazardous and nonhazardous constituents. The concentrations of hazardous constituents will be contoured to estimate the actual contamination distributions; the concentrations of nonhazardous constituents will be contoured and evaluated as indicators of ground-water and contaminant movement. The rate and extent of contamination will be conceptually evaluated based on existing data and modeling results (discussed below).

\section{Rate of Movement}

The rate of contaminant movement will be estimated initially by using values of hydraulic conductivity estimated from aquifer testing, the hydrau1 ic gradient determined from water-level measurements, and an estimated effective porosity based on the nature of the geologic material. This gross estimate will be applied in modeling studies and additional monitoring programs. The rate and extent of contanination will be conceptually evaluated based on existing data and modeling results (discussed below). The results of the evaluation will provide insight into the areas of greatest uncertainty and thus those areas where additional data are needed. Additional wells and field testing will most likely be necessary to quantify the rate and extent of contamination.

\section{Additional Well Installations}

Examination of the analytical results obtained under Phase I, coupled with those from preliminary flow and transport modeling (discussed below) 
will provide the basis on which to locate additional monitoring wells. Data from these wells will be used to further define and quantify the rate and extent of contamination.

\section{Additional Field and Laboratory Testing}

Samples will be collected from new and existing wells and analyzed for known hazardous waste or hazardous waste constituents and other constituents that will be useful for evaluating rate and extent of contamination. The primary focus of additional field or laboratory testing will be those parameters with the highest uncertainty and that most affect flow and transport. These factors will be evaluated by preliminary modeling and sensitivity analyses. Additional field and/or laboratory testing may be conducted to obtain

- quantitative and representative values of hydraulic conductivity and their distribution

- quantitative values of porosity

- more accurate spatial and temporal distributions of hydraulic head

- retardation characteristics

- quantitative values of dispersivity.

Modeling

Simple analytical models that include terms for dispersion, retardation, and radioactive decay will be used to simulate the extent and rate of contaminant plume movement based on assumed hydraulic and retardation parameters. Numerical mode1s that can accommodate heterogeneities in the hydrogeologic system and more complex transport conditions can also be used to estimate the rate and direction of flow under various hydrologic conditions. Models having verified codes will be used. As previously mentioned, the results of modeling will be used to locate additional wells that might be required and to identify data needs. 


\section{CONTINUED ANALYSIS AND EVALUATION}

This section discusses the review and evaluation that will be conducted on the initiation of assessment-level monitoring. It also discusses the required notifications and reports.

\section{Review of Methods and Procedures}

On verification of contamination in ground-water monitoring wells, the monitoring system, data evaluation methods, and sampling and analys is procedures will be reviewed. This review will evaluate whether the detection monitoring system is adequate to determine if contamination may be originating from a source other than the 2101-M pond. The method of establishing background will also be reviewed for its appropriateness within the hydrogeologic system. This review will consider the potential effects of other facilities that may result in trends in background water quality that have not been addressed in establishing background. Finally, the review will evaluate the current sampling and analysis procedures, and whether sample bias may result from inadequacies in the procedures.

\section{Review of Sampling Parameters and Frequency}

The sampling plan will be reviewed to evaluate if the appropriate parameters are being analyzed and if the frequency is adequate. The assessment-level monitoring program will require the addition to the list of parameters those hazardous constituents that have been detected. The sampling frequency will be returned to quarterly from semiannually in assessment-level monitoring until it is determined that no hazardous waste or hazardous waste constituents from the $2101-M$ pond have entered the ground water, or until final closure of the facility, as required per 40 CFR 265, Subpart $F$.

\section{Notification and Reports}

Table 4.2 lists the reports and notifications that must be submitted. In addition to these reports and notifications, records of the detectionlevel ground-water quality analyses, associated ground-water surface 
TABLE 4.2. Reports and Notifications for an Assessment-Level
Monitoring Program Submittal

In a11 circumstances

First year of sampling only: concentrations of interim primary drinking water standards, identify-

ing those that exceed the limits

listed in Table 3.1

Concentration and statistical analyses of ground-water contamination indicator parameters, noting significant differences in upgradient wells

Results of ground-water surface elevation evaluation and description of response, if appropriate

\author{
Submittal Period \\ Annually by March 1 of following \\ year Within 15 days of completion of quarterly analysis

When the facility might be affecting the ground-water (determined by Student's t-test)

Notification to EPA and Ecology that the facility might be affecting ground water

Submittal of ground-water assessment plan to EPA and Ecology

Submittal to EPA and Ecology of a written report on assessment-level ground-water quality, including concentrations of hazardous waste constituents and their rate and extent of migration
Within 7 days, confirmation of a significant increase (or $\mathrm{pH}$ decrease)

Within 15 days of the above notification

Within 15 days of first determination (as soon as technically feasible)

elevations, and the various data analyses (including the statistical analyses) will be kept throughout the active life of the 2101-M pond and throughout the post-closure period as wel1 [40 CFR 265.94(a)(1)]. 


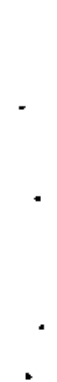




\subsection{REFERENCES}

40 CFR 261. 1987. U.S. Environmental Protection Agency, "Identification and Listing of Hazardous Waste." U.S. Code of Federal Regulations, Office of the Federal Register, Washington, D.C.

40 CFR 265. 1987. U.S. Environmental Protection Agency, "Interim Status Standards for Owners and Operators of Hazardous Waste Treatment, Storage, and Disposal Facilities." U.S. Code of Federal Regulations, Office of the Federal Register, Washington, D.C.

Bergeron, M. P., G. V. Last, and A. E. Reisenauer. 1987. Geohydrology of a Commercial Low-Level Radioactive Waste Disposal Facility Near Richland, Washington. PNWD-1127, Pacific Northwest Laboratory, Richland, Washington.

Bjornstad, B. N. 1984. Suprabasa7t Stratjgraphy Within and Adjacent to the Reference Repository Location. SD-BWI-DP-039, Rockwell Hanford Operations, Richland, Washington.

Caggiano, J. A., and D. W. Duncan (eds.). 1983. Preliminary Interpretation of the Tectonic Stability of the Reference Repository Location, Cold Creek Syncline, Hanford Site. RHO-BWI-ST-19P, Rockwell Hanford Operations, Richland, Washington.

D0E. 1987. 2101-M Preliminary Closure/Post-Closure Plan. U.S. Department of Energy, Richland, Washington.

D0E. 1988. Consultation Draft, Site Characterization Plan, Reference Repository Location, Hanford Site, Washington. DOE/RW-0164, Vol. 1, U.S. Department of Energy, Richland, Washington.

Ecology. 1986. Dangerous Waste Regulations, WAC 173-303. Washington State Department of Ecology, OTympia, Washington.

Ecology. 1988. Minimum We11 Construction Standards, WAC 173-303-160.

Washington State Department of Ecoiogy, 01ympia, Washington.

EPA. 1982. Test Methods for Evaluating Solid Waste. SW-846, 2nd edition, U.S. Environmental Protection Agency, Washington, D.C.

EPA. 1986. RCRA Ground-Water Monitoring Technical Enforcement Guidance Oocument (TEGD). OSWER-9950.1, U.S. Environmental Protection Agency, Washington, D.C.

Fecht, K. R., S. P. Reidel, and A. M. Tajlman. 1985. Paleodrainage of the Columbia River System on the Columbia Plateau of Washington State: A Summary. RHO-BW-SA-318P, Rockwell hanford Operations, Richland, Washington.

Gee, G. W. 1987. Recharge at the Hanford Site: Status Report. PNL-6403, Pacific Northwest Laboratory, Richland, Washington. 
Gephart, R. E., R. C. Arnett, R. G. Baca, L. S. Leonhart, and F. A. Spane, Jr. 1979. Hydrologic Studies With in the Columbia Plateau, Washington: An Integration of Current Knowledge. RHO-BWI-ST-5, Rockwe1T Hanford Operations, Richland, Washington.

Graham, M. J., M. D. Hal1, S. R. Strait, and W. R. Brown. 1981. Hydrology of the Separations Area. RHO-ST-42, Rockwell Hanford Operations, Richland, Washington.

Graham, M. J., G. V. Last, and K. R. Fecht. 1984. An Assessment of Aquifer Intercommunication in the B Pond-Gable Mountain Pond Area of the Hanford Site. RHO-RE-ST-12-P, Rockwell Hanford Operations, Richland, Washington.

Jungfleisch, F. 1988. Preliminary Evaluation of Hanford Liquid Discharges to Ground. WHC-EP-0052, Westinghouse Hanford Company, Richland, Washington.

Last, G. V., and T. L. Liikala. 1987. A Fjeld Guide for Well Site Geologists: Cable Tool Drilling. PNL-6392, Pacific Northwest Laboratory, Richiand, Washington.

Law, A. G., J. A. Serkowski, and A. L. Schatz. 1987. Results of Separations Area Ground-Water Monitoring Network for 1986. RH0-RE-SR-87-24-P, Rockwe1T Hanford Operations, Richland, Washington.

McDonaid, M. G., and A. W. Harbaugh. 1984. A Modular Three-Dimensional FiniteDifference Ground-Water Flow Model. U.S. Geological Survey Open-File Report 83-875, U.S. Geological Survey, Denver, Colorado.

Myers, C. W./S. M. Price, J. A. Caggiano, M. P. Cochran, W. H. Czimer, N. J. Davidson, R. C. Edwards, K. R. Fecht, G. E. Holmes, M. G. Jones, J. R. Kunk, R. D. Landon, R. K. Ledgerwood, J. T. Lillie, P. E. Long, T. H. Mitchell, E. H. Price, S. P. Reidel, and A. M. Tallman. 1979. Geologic Studies of the Columbia Plateau: A Status Report. RHO-BWI-ST-4, Rockwe 11 Hanford Operations, Richland, Washington.

Myers, C. W., and S. M. Price (eds.) 1981. Subsurface Geology of the Cold Creek Syncline. RHO-BWI-ST-14, Rockwell Hanford Operations, Rich7and, Washington.

PSPL. 1982. Skagit/Hanford Nuclear Project, Application For Site Certification/Environmental Report. Vol. 2, Chapters 4-8, Bellevue, Washington.

Reidel, S. P., K. R. Fecht, and R. W. Cross. 1982. "Constraints on Tectonic Models for the Columbia Plateau from the Age and Growth Rates of Yakima Folds." In Proceedings, 33rd Alaska Science Conference, Vol. 12, Arctic Division, American Association for Advancement of Science.

Rockwe 11. 1987. Environmenta] Protection Manual. RHO-MA-139-P, rev. 0, Rockwell Hanford Operations, Richland, Washington. 
Schatz, A. L., and J. J. Ammerman. 1988. Ground-Water Maps of the Hanford Site Separations Area, December, 1987. WHC-EP-0142, Westinghouse Hanford Company, Richland, Washington.

Serkowski, J. A., A. G. Law, J. A. Ammerman, and A. L. Schatz. 1988 . Results of Ground-Water Monitoring for Radionuclides in the Separations Area-1987. WHC-EP-0152, Westinghouse Hanford Company, Richland, Washington.

Swanson, D. A., T. L. Wright, P. R. Hooper, and R. D. Bentley. 1979. Revisions in Stratigraphic Nomenclature of the Columbia River Basalt Group. Bulletin 1457-G, U.S. Geological Survey, Washington, D.C.

Supply System (WPPSS). 1981. Final Safety Analysis Report, WPPSS Nuclear Project No._.2. Amendment 18, Richland, Washington.

Ta11man, A. M., K. R. Fecht, M. C. Marratt, and G. V. Last. 1979. Geology of the Separations Area, Hanford Site, South-Central Washington. RHO-ST-23, Rockwell Hanford Operations, Richland, Washington.

Webster, C. T. 1977. Ringold Identification, Correlation, and Sampling Program, Wel1 History $\mathrm{DH}-11,-12,-13,-13 \mathrm{~A},-14,-15,-16$, and -17 , (Continuation of ARH-C-13, Hanford Works, Washington. RHO-LD-34, Rockwe 11 Hanford Operations, Richland, Washington. 


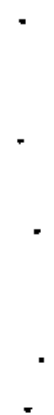


APPENDIX A

DRILLING AND WELL CONSTRUCTION LOGS 


\section{APPENDIX A}

\section{DRILLING ANO WELL CONSTRUCTION LOGS}

Drilling logs from existing wells in the vicinity of the 2101-M pond are included here for reference. These logs were constructed from wells drilled by Rockwe11 Hanford Operations and Pacific Northwest Laboratory. The lithologic and well construction information was obtained from driller's logs or geologist's logs, where available. The well log information was used, where possible, to substantiate site-specific geologic information and evaluate the construction. The following well logs were reviewed and are included in this appendix:

\section{Well Number}

299-E13-14

299-E19-1

299-E23-2
Date Completed

$12 / 56$

$12 / 57$

$5 / 65$
Location (by Hanford coordinate number

N $36080 / W 55150$

N $38085 / W 56023$

N $40000 / W 53000$ 


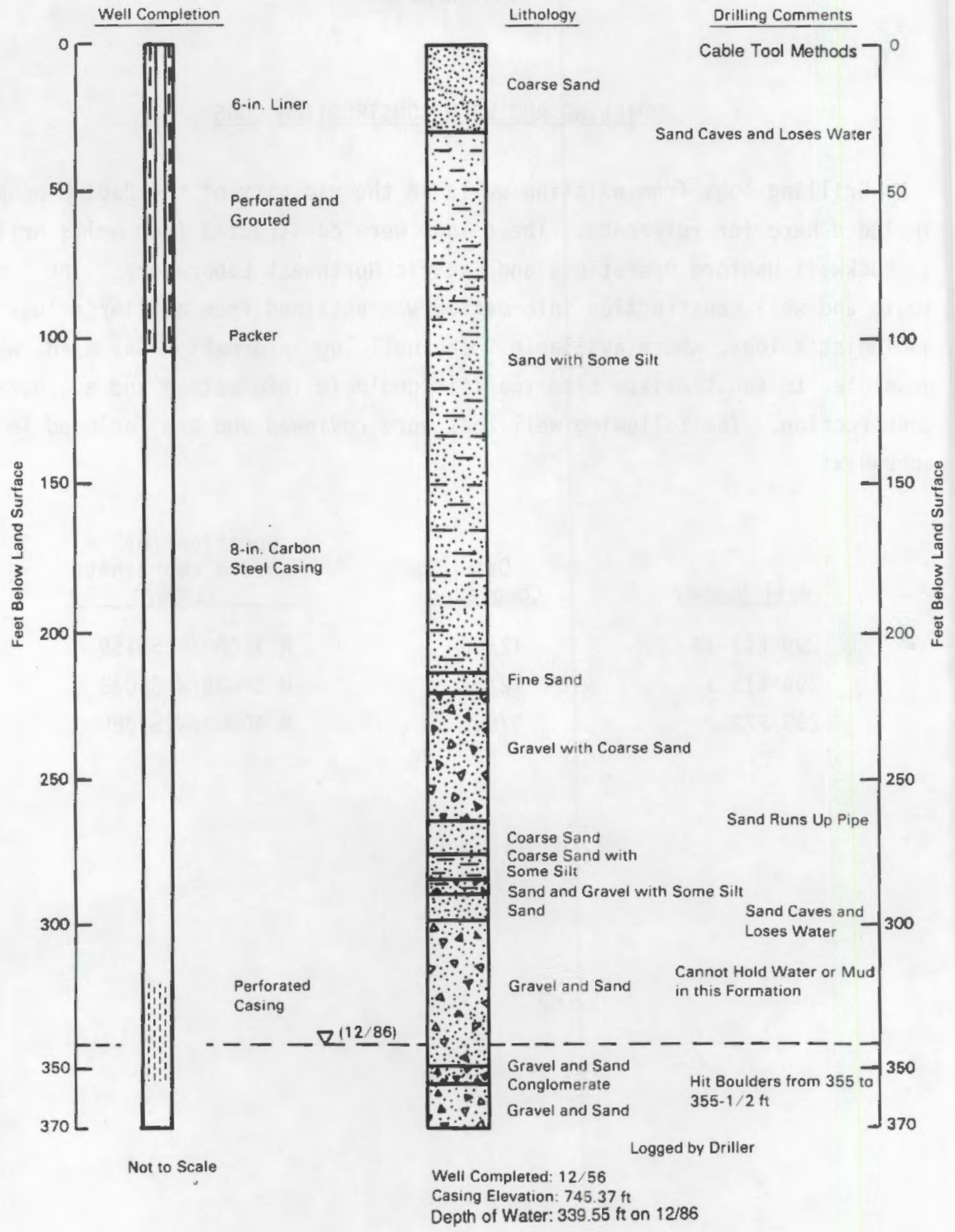

\section{A. 2}




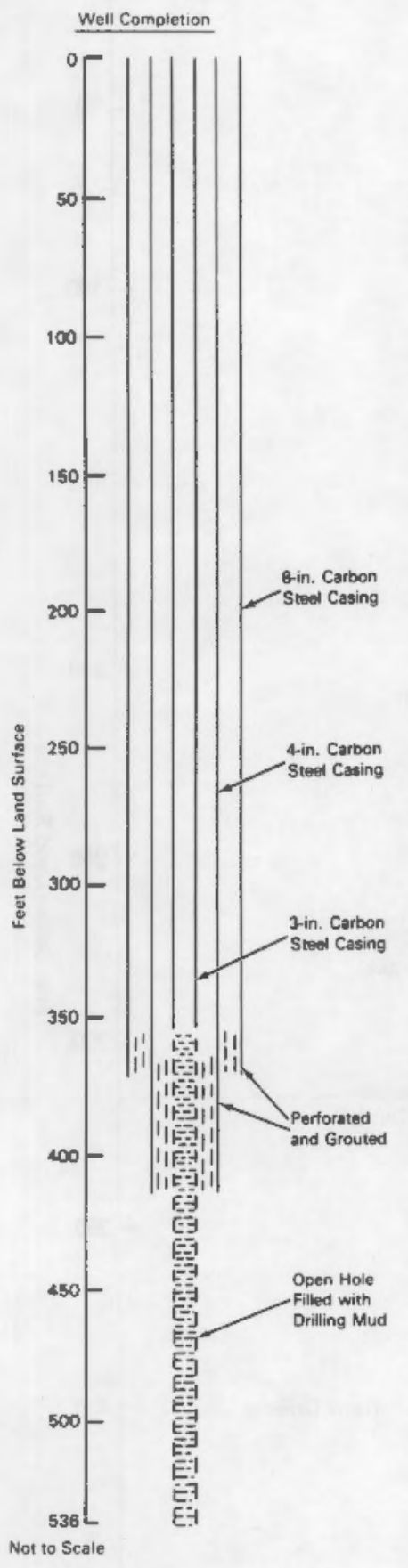

299-E19-1

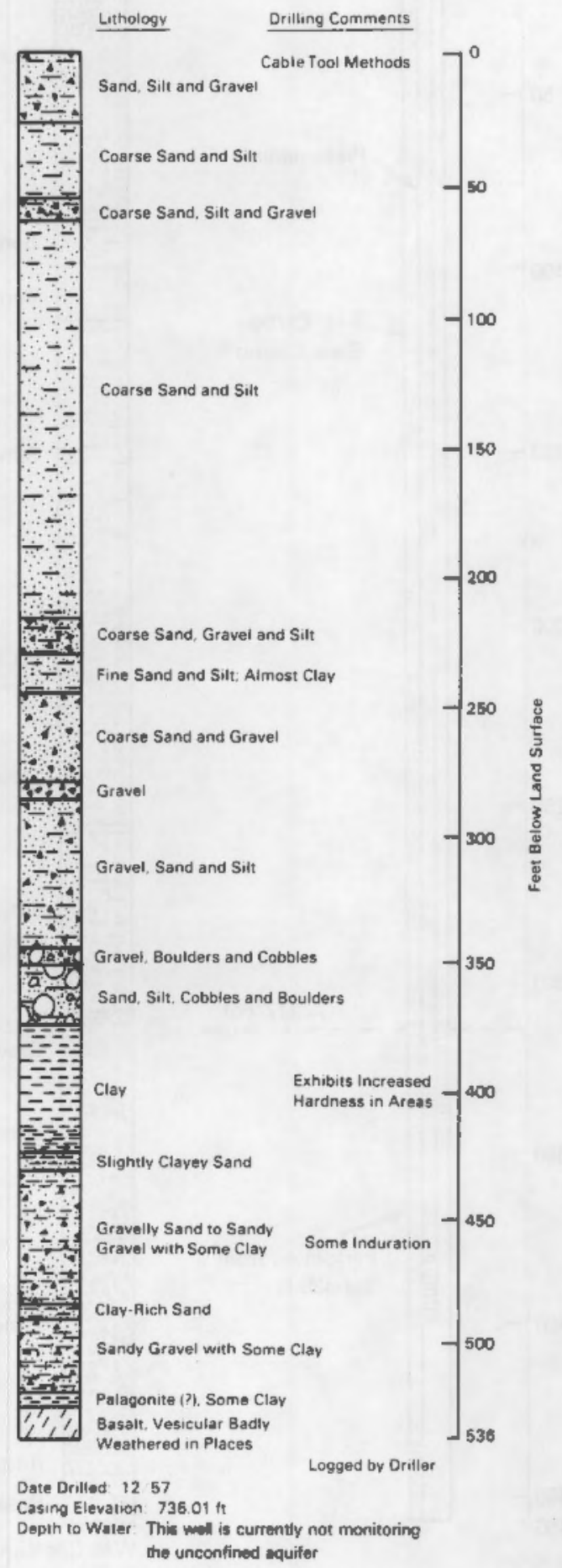

\section{A. 3}




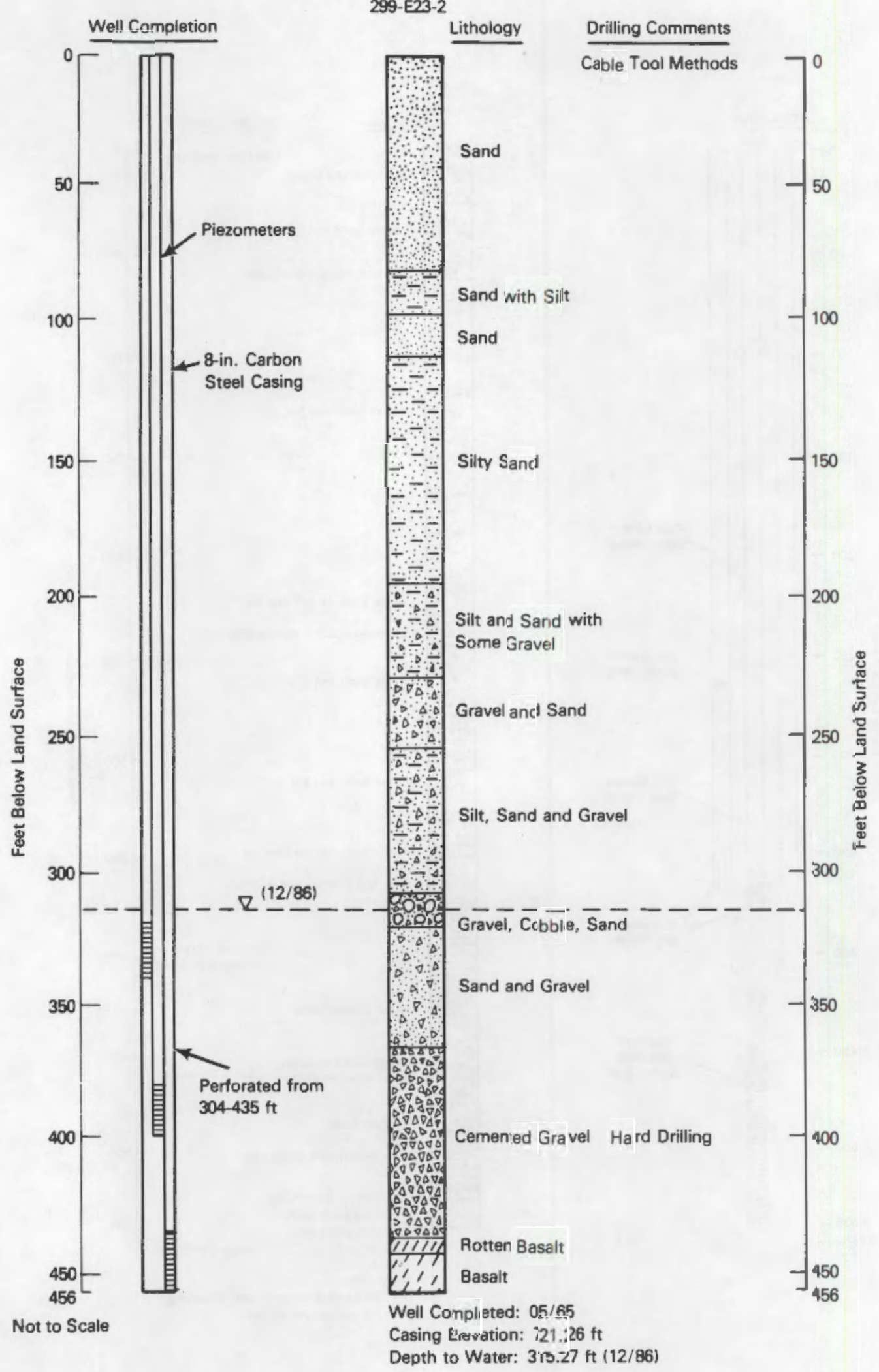

A. 4 
APPENDIX B

DATA LISTINGS AND SUMMARIES 


\section{APPENDIX B}

\section{DATA LISTINGS AND SUMMARIES}

This appendix presents an excerpt of existing chemical data available for wells near the 2101-M pond. Samples from 200-East Area wells have been analyzed for the various parameters 1 isted in Table B.1, although samples from the vicinity of the 2101-M pond have not been analyzed for all these parameters. Table B.2 lists the constituents that have been analyzed for in the wells near the pond. Less-than flags indicate that the samples were below detection limits. Minus signs appearing for certain radiological constituents indicate that the samples were below background radiation levels. 
IABLE B.1. Sample Parameters

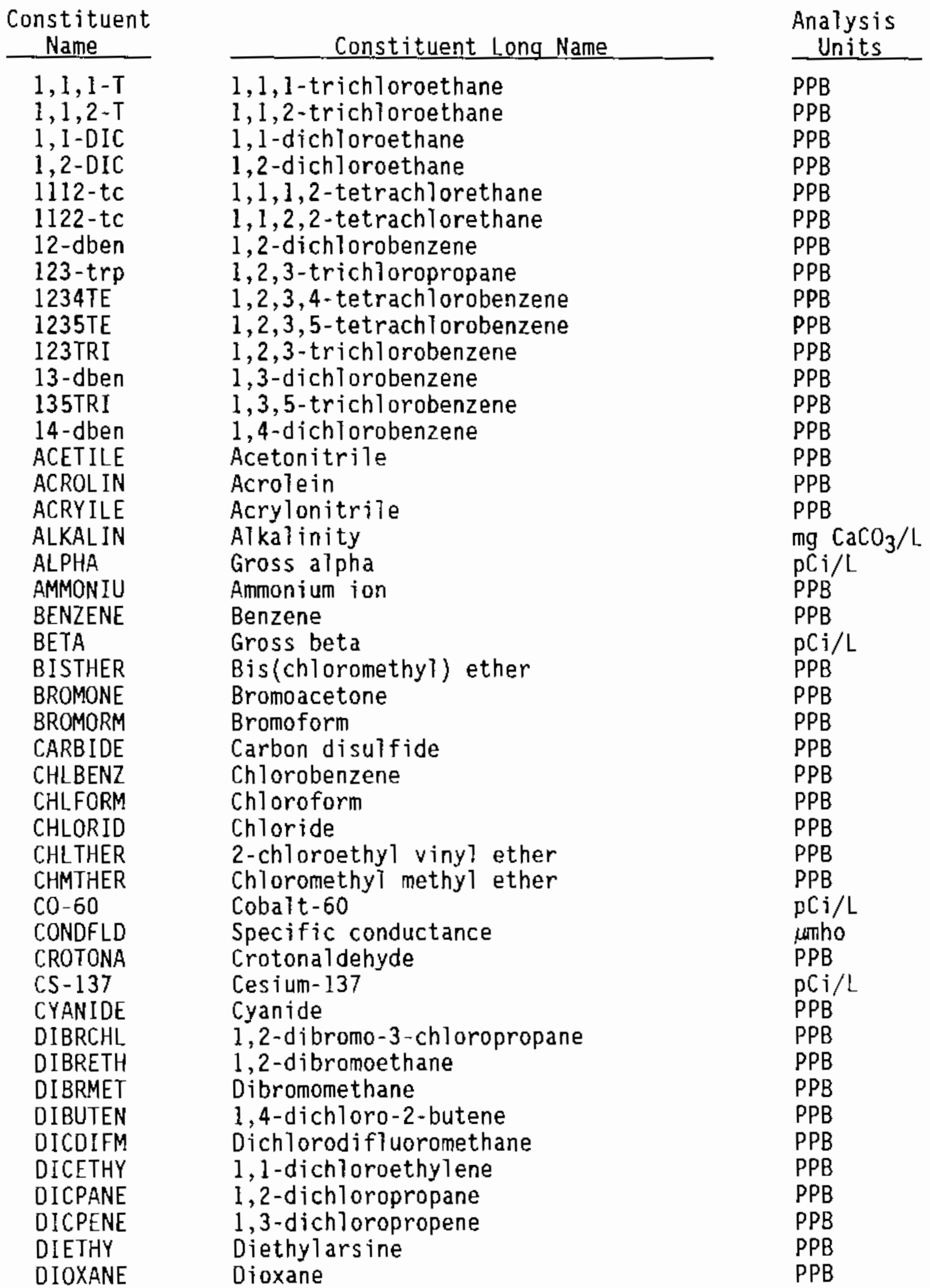


TABLE B.1. (contd)

Constituent Name

ETHMETH

ETHOXID

FALUMIN

FANTIMO

FARSENI

FBARIUM

FBERYLL

FCADMIU

FCALCIU

FCHROMI

FCOPPER

FIRON

FLEAD

FLUORID

FMAGNES

FMANGAN

FMERCUR

FNICXEL

FORMALN

FPOTASS

FSELENI

FSILVER

FSODIUM

FSTRONT

FVANADI

FZINC

HEXACHL

HEXCBEN

HEXONE

HNITRAT

HYORSUL

IODOMET

KEROSEN

LFLUORD

$M-X Y L E$

METACRY

METHACR

METHBRO

METHCHL

METHONE

METHTHI

METHYCH

NAPHTHA

NITRATE

NNDIEHY

OPXYLE
Constituent Long Name

Ethyl methacrylate

Ethylene oxide

Aluminum, filtered

Antimony, filtered

Arsenic, filtered

Barium, filtered

Beryllium, filtered

Camium, filtered

Calcium, filtered

Chromium, filtered

Copper, filtered

Iron, filtered

Lead, filtered

Fluoride

Magnesium, filtered

Manganese, filtered

Mercury, filtered

Nickel, filtered

Formal in

Potassium, filtered

Selenium, filtered

Silver, filtered

Sodium, filtered

Strontium, filtered

Vanadium, filtered

Zinc, filtered

Hexachlorophene

Hexachlorobenzene

Hexone

Nitrate, high detection level

Hydrogen sulfide

Iodomethane

Kerosene

Fluoride, low detection level

Xylene-m.

Methyl methacrylate

Methacrylonitrile

Methyl bromide

Methyl chloride

Methyl ethyl ketone

Methanethio?.

Methylene chloride

Naphthalene

Nitrate

$\mathrm{N}, \mathrm{N}$-diethylhydrazine

$x y l$ ene-o, $p$
Analysis

Units

PPB

PPB

PPB

PPB

PPB

PPB

PPB

PPB

PPB

PPB

PPB

PPB

PPB

PPB

PPB

$P P B$

PPB

PPB

PPB

PPB

PPB

$P P B$

$P P B$

PPB

PPB

PPB

PPB

PPB

PPB

PPB

PPB

PPB

PPB

PPB

PPB

$P P B$

PPB

PPB

PPB

PPB

PPB

PPB

$P P B$

$P P B$

$P P B$

PPB 
TABLE B.1. (contd)

Constituent Name

PENTACH

PENTCHB

PERCENE

$P H-L A B$

PHENOL

PHFIELD

PHOSPHA

PU-238

PU39-40

PYRIDIN

RU-106

SR 90

SULFATE

TC

TC-99

TETRANE

TETRCHB

TOC

TOLUENE

TOXLDL

TRANOCE

TRCMEOL

TRCMFLM

TRCPANE

TRIBUPH

TRICENE

TRICHLB

TRITIUM

$U$

VINYIDE
Const ituent Long Name

Pentachloroethane

Pentachlorobenzene

Perch loroethylene

$\mathrm{pH}$, laboratory measurement

Phenol

$\mathrm{pH}$, field measurement

Phosphate

P1utonium-238

P] utonium-239/40

Pyridine

Ruthenium-106

Strontium-90

Sulfate

Total carbon

Technet ium-99

Tetrachloromethane

$1,2,4,5$-tetrach Torobenzene

Total organic carbon

Toluene

Total organic halogen, low det. level

Trans-1,2-dichloroethene

Trichloromethanethiol

Trichloromonof]uoromethane

Trichioropropane

Tributylphosphoric acid

Trichloroethylene

1,2,4-trichlorobenzene

Tritium

Uranium

Vinyl chloride
Analysis

Units

PPB

PPB

PPB

PPB

PPB

$\mathrm{PCi} / \mathrm{L}$

$\mathrm{pC} i / L$

PPB

$\mathrm{PC} i / L$

pCi/L

PPB

PPB

$\mathrm{pC} \dot{\mathrm{i}} / \mathrm{L}$

PPB

PPB

PPB

PPB

PPB

PPB

PPB

PPB

PPB

PPB

PPB

PPB

$\mathrm{pCi} / \mathrm{L}$

pCi/L

PPB 
IABLE B.2. Ground-Water Data

\begin{tabular}{|c|c|c|c|c|c|c|}
\hline $\begin{array}{l}\text { WELL } \\
\text { NANE (a) }\end{array}$ & $\begin{array}{l}\text { COLLECT IDN } \\
\text { DATE }\end{array}$ & $\begin{array}{l}\text { CONSTITUENT } \\
\text { CODE }\end{array}$ & $\begin{array}{l}\text { CONSTITUENT } \\
\text { NANE }\end{array}$ & $\begin{array}{l}\text { LESS } \\
\text { THAN } \\
\text { FLAG }\end{array}$ & $\begin{array}{l}\text { ANALYSIS } \\
\text { VALUE }\end{array}$ & $\begin{array}{l}\text { ANALYSIS } \\
\text { UNITS }\end{array}$ \\
\hline $\begin{array}{l}2-E 13-14 \\
2-E 13-14 \\
2-E 13-14 \\
2-E 13-14 \\
2-E 13-14 \\
2-E 13-14 \\
2-E 13-14 \\
2-E 13-14 \\
2-E 13-14 \\
2-E 13-14 \\
2-E 13-14 \\
2-E 13-14 \\
2-E 13-14 \\
2-E 13-14 \\
2-E 13-14 \\
2-E 13-14 \\
2-E 13-14 \\
2-E 13-14 \\
2-E 13-14 \\
2-E 13-14 \\
2-E 13-14 \\
2-E 13-14 \\
2-E 13-14 \\
2-E 13-14 \\
2-E 13-14 \\
2-E 13-14 \\
2-E 13-14 \\
2-E 13-14 \\
2-E 13-14 \\
2-E 13-14 \\
2-E 13-14 \\
2-E 13-14 \\
2-E 13-14 \\
2-E 13-14 \\
2-E 13-14 \\
2-E 13-14 \\
2-E 13-14 \\
2-E 13-14 \\
2-E 13-14 \\
2-E 13-14 \\
2-E 13-14 \\
2-E 13-14 \\
2-E 13-14 \\
2-E 13-14 \\
2-E 13-14\end{array}$ & 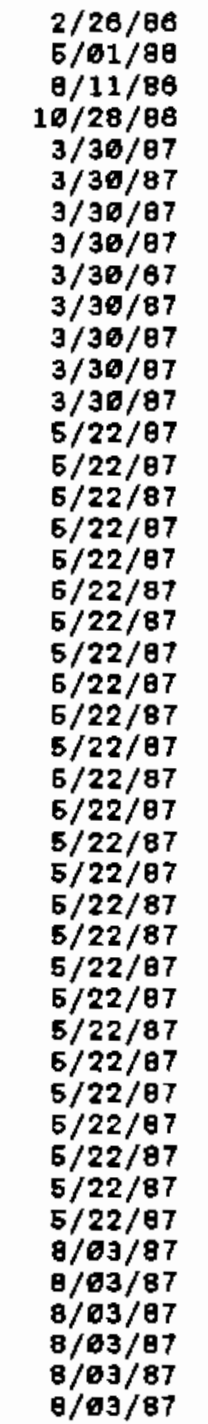 & $\begin{array}{l}111 \\
111 \\
111 \\
111 \\
610 \\
024 \\
034 \\
100 \\
102 \\
104 \\
108 \\
111 \\
121 \\
111 \\
111 \\
191 \\
199 \\
207 \\
212 \\
181 \\
A 84 \\
187 \\
A 88 \\
A 69 \\
A 70 \\
A 71 \\
A 80 \\
A 93 \\
814 \\
C 89 \\
C 70 \\
C 72 \\
C 73 \\
C 74 \\
C 75 \\
C 78 \\
C 80 \\
H 42 \\
H 58 \\
010 \\
024 \\
634 \\
100 \\
102 \\
104\end{array}$ & 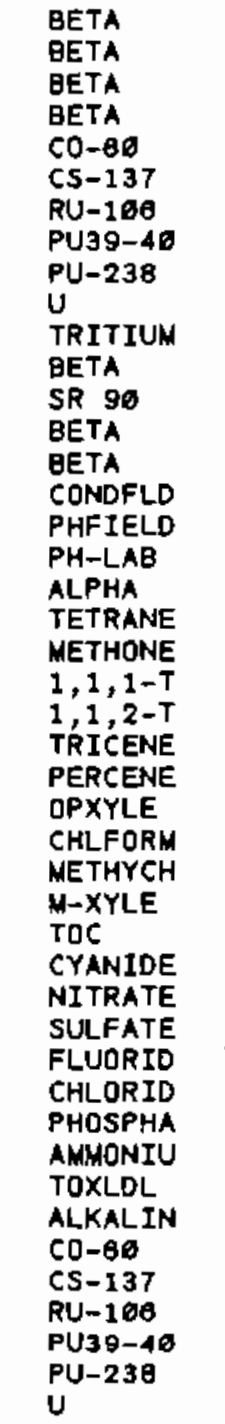 & $\begin{array}{l}< \\
< \\
k \\
k \\
k \\
k \\
k \\
k \\
k \\
k\end{array}$ & 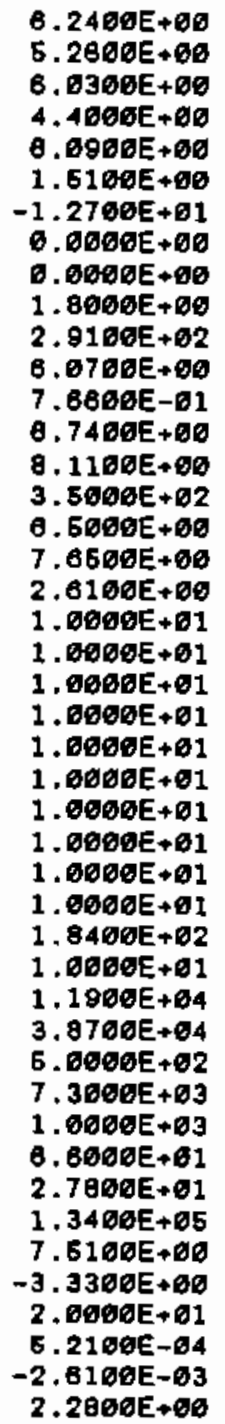 & $\begin{array}{l}P C I / L \\
P C I / L \\
P C I / L \\
P C I / L \\
P C I / L \\
P C I / L \\
P C I / L \\
P C I / L \\
P C I / L \\
P C I / L \\
P C I / L \\
P C I / L \\
P C I / L \\
P C I / L \\
P C I / L \\
U N H O \\
\\
P C I / L \\
P P B \\
P P B \\
P P B \\
P P B \\
P P B \\
P P B \\
P P B \\
P P B \\
P P B \\
P P B \\
P P B \\
P P B \\
P P B \\
P P B \\
P P B \\
P P B \\
P P B \\
P P B \\
P P B \\
P C I / L \\
P C I / L \\
P C I / L \\
P C I / L \\
P C I / L \\
P C I / L \\
P B\end{array}$ \\
\hline
\end{tabular}

(a) All wells prefixed by 299-. 
IABLE_B.2. (contd)

\begin{tabular}{|c|c|c|c|c|c|c|}
\hline $\begin{array}{l}\text { WELL } \\
\text { NAME }\end{array}$ & $\begin{array}{c}\text { COLLECTION } \\
\text { DATE }\end{array}$ & $\begin{array}{c}\text { CONSTI TUENT } \\
\text { COOE }\end{array}$ & $\begin{array}{l}\text { CONS TITUENT } \\
\text { NAME }\end{array}$ & $\begin{array}{l}\text { LESS } \\
\text { THAN } \\
\text { FLAG }\end{array}$ & $\begin{array}{l}\text { ANALYSIS } \\
\text { VALUE }\end{array}$ & $\begin{array}{l}\text { ANALYSIS } \\
\text { UNITS }\end{array}$ \\
\hline $\begin{array}{l}2-E 13-14 \\
2-E 13-14 \\
2-E 13-14 \\
2-E 13-14 \\
2-E 13-14 \\
2-E 13-14 \\
2-E 13-14 \\
2-E 13-14 \\
2-E 13-14 \\
2-E 13-14 \\
2-E 13-14 \\
2-E 13-14 \\
2-E 13-14 \\
2-E 13-14 \\
2-E 13-14 \\
2-E 13-14 \\
2-E 13-14 \\
2-E 13-14 \\
2-E 13-14 \\
2-E 13-14 \\
2-E 13-14 \\
2-E 13-14 \\
2-E 13-14 \\
2-E 13-14 \\
2-E 13-14 \\
2-E 13-14 \\
2-E 13-14 \\
2-E 13-14 \\
2-E 13-14 \\
2-E 13-14 \\
2-E 13-14 \\
2-E 13-14 \\
2-E 13-14 \\
2-E 13-14 \\
2-E 13-14 \\
2-E 13-14 \\
2-E 13-14 \\
2-E 13-14 \\
2-E 13-14 \\
2-E 13-14 \\
2-E 13-14 \\
2-E 13-14 \\
2-E 13-14 \\
2-E 13-14 \\
2-E 13-14\end{array}$ & 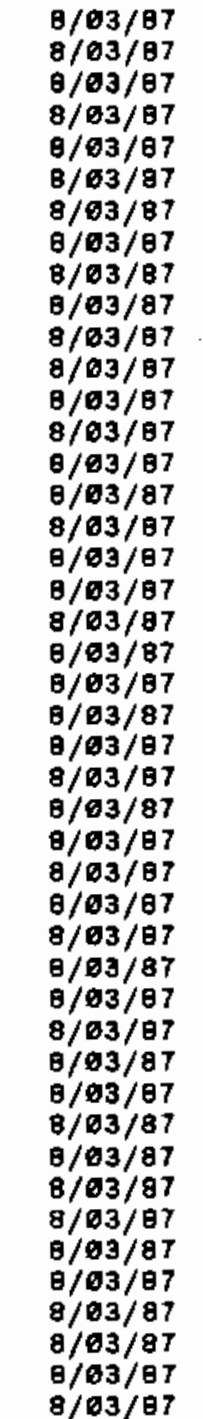 & $\begin{array}{l}168 \\
111 \\
111 \\
121 \\
191 \\
199 \\
207 \\
212 \\
A B 1 \\
A 62 \\
A 63 \\
A 64 \\
A 65 \\
A B 6 \\
A B 7 \\
A 68 \\
A B 9 \\
A 76 \\
A 71 \\
A 72 \\
A 73 \\
A 74 \\
A 75 \\
A 76 \\
A 77 \\
A 7 B \\
A 79 \\
A 9 B \\
A B 1 \\
A 82 \\
A 83 \\
A B 4 \\
A B 5 \\
A B B \\
A 87 \\
A B 8 \\
A B 9 \\
A 90 \\
A 91 \\
A 92 \\
A 93 \\
A 94 \\
A 95 \\
A 96 \\
A 99\end{array}$ & $\begin{array}{l}\text { TRITIUM } \\
\text { BETA } \\
\text { BETA } \\
\text { SR 9Q } \\
\text { CONDFLD } \\
\text { PHFIELD } \\
\text { PH-LAB } \\
\text { ALPHA } \\
\text { TETRANE } \\
\text { BENZENE } \\
\text { DIOXANE } \\
\text { METHONE } \\
\text { PYRIDIN } \\
\text { TOLUENE } \\
1, \text { I, 1-T } \\
1,1,2-T \\
\text { TRICENE } \\
\text { PERCENE } \\
\text { OPXYLE } \\
\text { ACROLIN } \\
\text { ACRYILE } \\
\text { BISTHER } \\
\text { BROMONE } \\
\text { METHERO } \\
\text { CARBIDE } \\
\text { CHLBENZ } \\
\text { CHLTHER } \\
\text { CHLFORH } \\
\text { METHCHL } \\
\text { CHMTHER } \\
\text { CROTONA } \\
\text { OIERCHL } \\
\text { DIBRETH } \\
\text { DIBRMET } \\
\text { DIBUTEN } \\
\text { DICDIFN } \\
1, I-D I C \\
1,2-D I C \\
\text { TRANOCE } \\
\text { DICETHY } \\
\text { METHYCH } \\
\text { DICPANE } \\
\text { DICPENE } \\
\text { NNDIEHY } \\
\text { HYDRSUL }\end{array}$ & 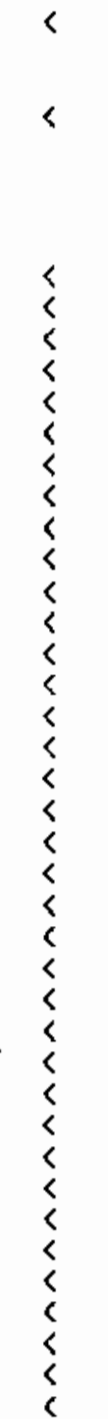 & 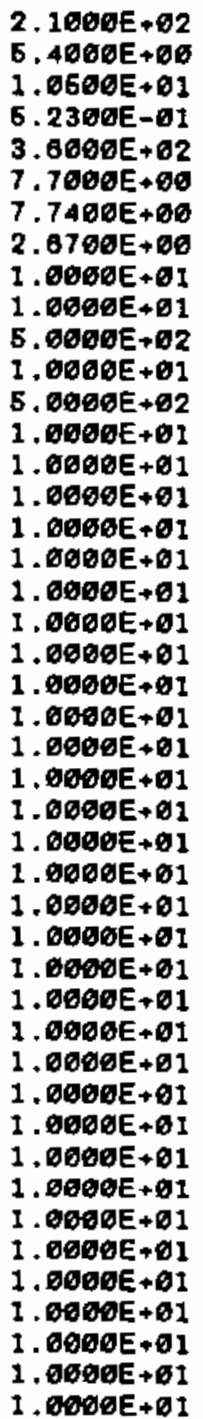 & 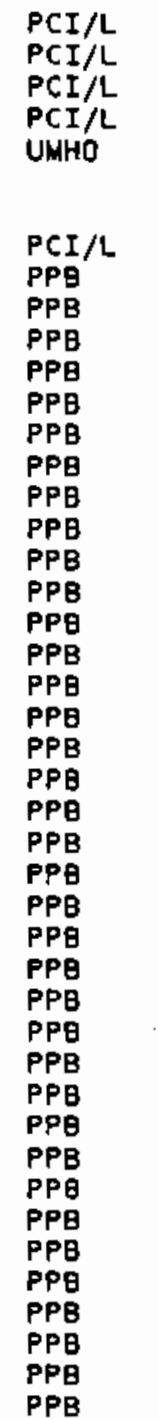 \\
\hline
\end{tabular}


TABLE B.2. (contd)

\begin{tabular}{|c|c|c|c|c|c|c|}
\hline $\begin{array}{l}\text { WELL } \\
\text { NAME }\end{array}$ & $\begin{array}{c}\text { COLLECTION } \\
\text { DATE }\end{array}$ & $\begin{array}{l}\text { CONSTITUENT } \\
\text { CODE }\end{array}$ & $\begin{array}{l}\text { CONSTI TUENT } \\
\text { NAME }\end{array}$ & $\begin{array}{l}\text { LESS } \\
\text { THAN } \\
\text { FLAG }\end{array}$ & $\begin{array}{l}\text { ANALYSIS } \\
\text { VALUE }\end{array}$ & $\begin{array}{l}\text { ANALYSIS } \\
\text { UNITS }\end{array}$ \\
\hline $\begin{array}{l}2-E 13-14 \\
2-E 13-14 \\
2-E 13-14 \\
2-E 13-14 \\
2-E 13-14 \\
2-E 13-14 \\
2-E 13-14 \\
2-E 13-14 \\
2-E 13-14 \\
2-E 13-14 \\
2-E 13-14 \\
2-E 13-14 \\
2-E 13-14 \\
2-E 13-14 \\
2-E 13-14 \\
2-E 13-14 \\
2-E 13-14 \\
2-E 13-14 \\
2-E 13-14 \\
2-E 13-14 \\
2-E 13-14 \\
2-E 13-14 \\
2-E 13-14 \\
2-E 13-14 \\
2-E 13-14 \\
2-E 13-14 \\
2-E 13-14 \\
2-E 13-14 \\
2-E 13-14 \\
2-E 13-14 \\
2-E 13-14 \\
2-E 13-14 \\
2-E 13-14 \\
2-E 13-14 \\
2-E 13-14 \\
2-E 13-14 \\
2-E 13-14 \\
2-E 13-14 \\
2-E 13-14 \\
2-E 13-14 \\
2-E 13-14 \\
2-E 13-14 \\
2-E 13-14 \\
2-E 13-14 \\
2-E 13-14\end{array}$ & 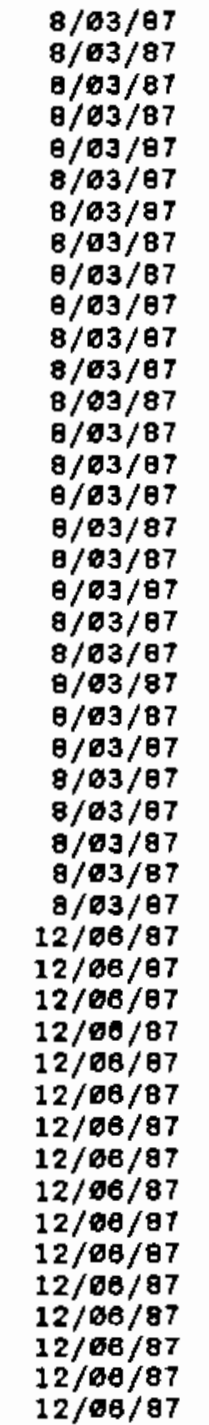 & 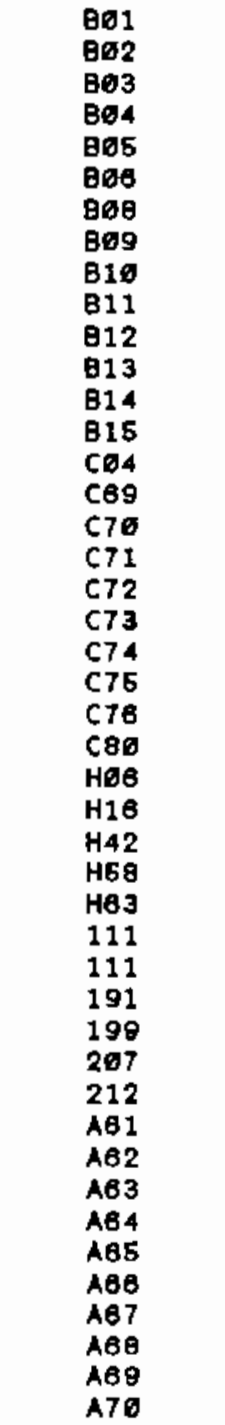 & $\begin{array}{l}\text { IODOMET } \\
\text { METHACR } \\
\text { METHTHI } \\
\text { PENTACH } \\
1112-\text { TE } \\
1122-\text { TC } \\
\text { BRONORM } \\
\text { TRCMEOL } \\
\text { TRCNFLN } \\
\text { TRCPANE } \\
\text { 123-trD } \\
\text { VINYIDE } \\
\text { M-XYLE } \\
\text { DIETHY } \\
\text { METACRY } \\
\text { TOC } \\
\text { CYANIDE } \\
\text { FORMALN } \\
\text { NITRATE } \\
\text { SULFATE } \\
\text { FLUORID } \\
\text { CHLORID } \\
\text { PHOSPHA } \\
\text { AMNONIU } \\
\text { ETHMETH } \\
\text { TC } \\
\text { TOXLDL } \\
\text { ALKALIN } \\
\text { LFLUORO } \\
\text { BETA } \\
\text { BETA } \\
\text { CONDFLD } \\
\text { PHFIELD } \\
\text { PH-LAB } \\
\text { ALPHA } \\
\text { TETRANE } \\
\text { OENZENE } \\
\text { DIOXANE } \\
\text { METHONE } \\
\text { PYRIOIN } \\
\text { TOLUENE } \\
1,1,1-T \\
1,1,2-T \\
\text { TRICENE } \\
\text { PERCENE }\end{array}$ & $\begin{array}{l}< \\
< \\
< \\
< \\
< \\
< \\
< \\
< \\
< \\
< \\
< \\
< \\
< \\
< \\
< \\
< \\
< \\
<\end{array}$ & 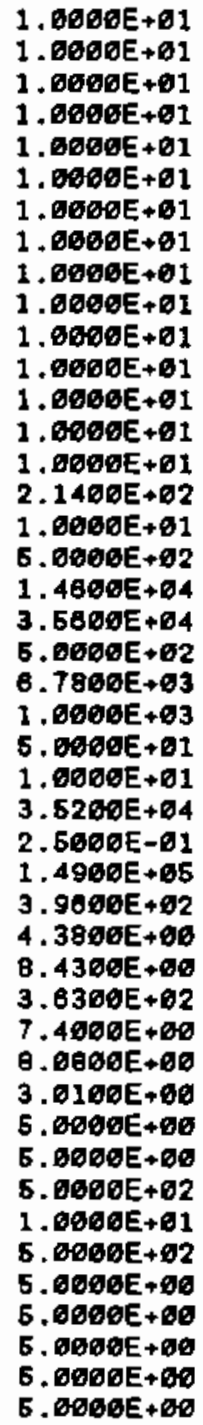 & $\begin{array}{l}\text { PPB } \\
\text { PPB } \\
\text { PPB } \\
\text { PPB } \\
\text { PPB } \\
\text { PPB } \\
\text { PPB } \\
\text { PPB } \\
\text { PPB } \\
\text { PPB } \\
\text { PPB } \\
\text { PPB } \\
\text { PPB } \\
\text { PPB } \\
\text { PPB } \\
\text { PPB } \\
\text { PPB } \\
\text { PPB } \\
\text { PPB } \\
\text { PPB } \\
\text { PPB } \\
\text { PPB } \\
\text { PPB } \\
\text { PPB } \\
\text { PPB } \\
\text { PPB } \\
\text { PPB } \\
\text { PPB } \\
\text { PCI } / \\
\text { PCI/ } \\
\text { UMHO } \\
\text { PCI/ } \\
\text { PPB } \\
\text { PPB } \\
\text { PPB } \\
\text { PPB } \\
\text { PPB } \\
\text { PPB } \\
\text { PPB } \\
\text { PPB } \\
\text { PPB }\end{array}$ \\
\hline
\end{tabular}


TABLE_B.2. (contd)

\begin{tabular}{|c|c|c|c|c|c|c|}
\hline $\begin{array}{l}\text { WELL } \\
\text { NAME }\end{array}$ & $\begin{array}{l}\text { COLLECTION } \\
\text { DATE }\end{array}$ & $\begin{array}{l}\text { CONSTITUENT } \\
\text { CODE }\end{array}$ & $\begin{array}{l}\text { CONSTITUENT } \\
\text { NAME }\end{array}$ & $\begin{array}{l}\text { LESS } \\
\text { THAN } \\
\text { FLAG }\end{array}$ & $\begin{array}{l}\text { ANALYSIS } \\
\text { VALUE }\end{array}$ & $\begin{array}{l}\text { ANALYSIS } \\
\text { UNITS }\end{array}$ \\
\hline $\begin{array}{l}2-E 13-14 \\
2-E 13-14 \\
2-E 13-14 \\
2-E 13-14 \\
2-E 13-14 \\
2-E 13-14 \\
2-E 13-14 \\
2-E 13-14 \\
2-E 13-14 \\
2-E 13-14 \\
2-E 13-14 \\
2-E 13-14 \\
2-E 13-14 \\
2-E 13-14 \\
2-E 13-14 \\
2-E 13-14 \\
2-E 13-14 \\
2-E 13-14 \\
2-E 13-14 \\
2-E 13-14 \\
2-E 13-14 \\
2-E 13-14 \\
2-E 13-14 \\
2-E 13-14 \\
2-E 13-14 \\
2-E 13-14 \\
2-E 13-14 \\
2-E 13-14 \\
2-E 13-14 \\
2-E 13-14 \\
2-E 13-14 \\
2-E 13-14 \\
2-E 13-14 \\
2-E 13-14 \\
2-E 13-14 \\
2-E 13-14 \\
2-E 13-14 \\
2-E I 3-14 \\
2-E 13-14 \\
2-E 13-14 \\
2-E 13-14 \\
2-E 13-14 \\
2-E 13-14 \\
2-E 13-14 \\
2-E 13-14\end{array}$ & 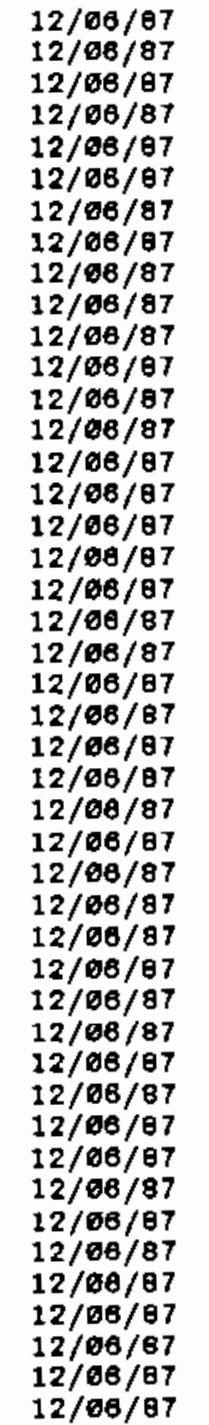 & 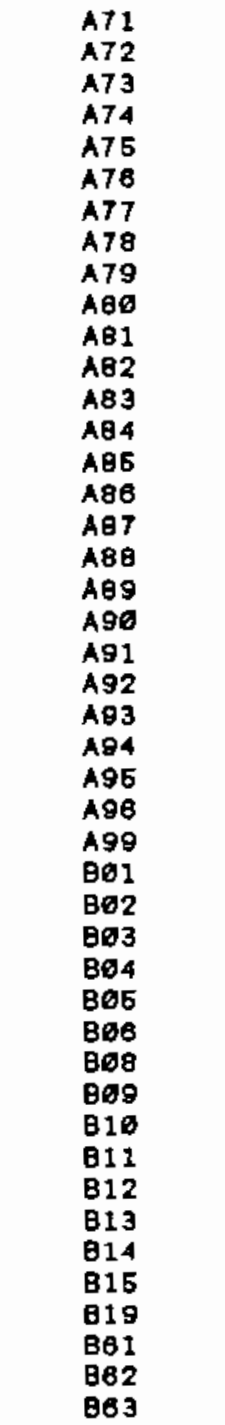 & 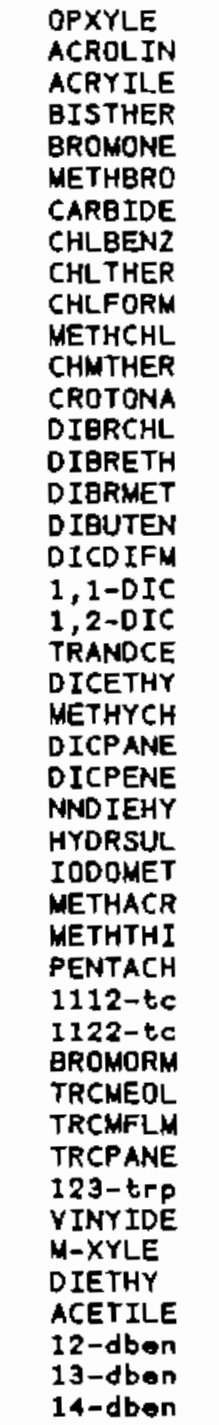 & 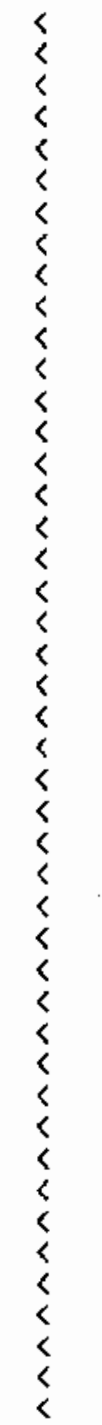 & 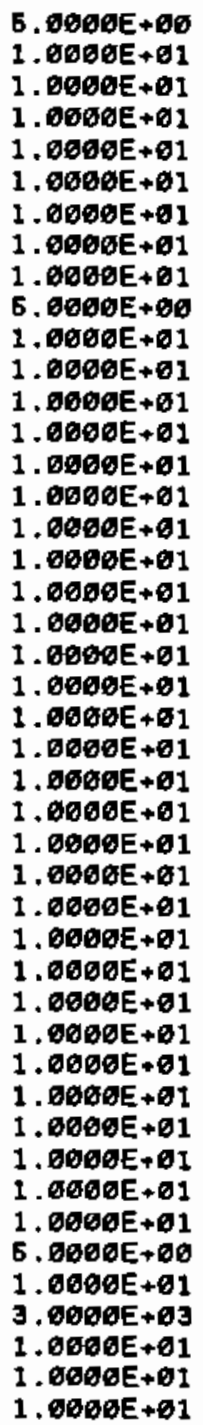 & $\begin{array}{l}P P B \\
P P B \\
P P B \\
P P B \\
P P B \\
P P B \\
P P B \\
P P B \\
P P B \\
P P B \\
P P B \\
P P B \\
P P B \\
P P B \\
P P B \\
P P B \\
P P B \\
P P B \\
P P B \\
P P B \\
P P B \\
P P B \\
P P B \\
P P B \\
P P B \\
P P B \\
P P B \\
P P B \\
P P B \\
P P B \\
P P B \\
P P B \\
P P B \\
P P B \\
P P B \\
P P B \\
P P B \\
P P B \\
P P B \\
P P B \\
P P B \\
P P B \\
P P B \\
P P B \\
P P B\end{array}$ \\
\hline
\end{tabular}


TABLE B.2. (contd)

\begin{tabular}{|c|c|c|c|c|c|c|}
\hline $\begin{array}{l}\text { WELL } \\
\text { NAME }\end{array}$ & $\begin{array}{c}\text { COLLECTION } \\
\text { DATE }\end{array}$ & $\begin{array}{l}\text { CONSTITUENT } \\
\text { CODE }\end{array}$ & $\begin{array}{l}\text { CONSTITUENT } \\
\text { NANE }\end{array}$ & $\begin{array}{l}\text { LESS } \\
\text { THAN } \\
\text { FLAG }\end{array}$ & $\begin{array}{l}\text { ANALYSIS } \\
\text { VALUE }\end{array}$ & $\begin{array}{l}\text { ANALYSIS } \\
\text { UNITS }\end{array}$ \\
\hline $\begin{array}{l}2-E 13-14 \\
2-E 13-14 \\
2-E 13-14 \\
2-E 13-14 \\
2-E 13-14 \\
2-E 13-14 \\
2-E 13-14 \\
2-E 13-14 \\
2-E 13-14 \\
2-E 13-14 \\
2-E 13-14 \\
2-E 13-14 \\
2-E 13-14 \\
2-E 13-14 \\
2-E 13-14 \\
2-E 13-14 \\
2-E 13-14 \\
2-E 13-14 \\
2-E 13-14 \\
2-E 13-14 \\
2-E 13-14 \\
2-E 13-14 \\
2-E 13-14 \\
2-E 13-14 \\
2-E 13-14 \\
2-E 13-14 \\
2-E 13-14 \\
2-E 13-14 \\
2-E 13-14 \\
2-E 13-14 \\
2-E 13-14 \\
2-E 13-14 \\
2-E 13-14 \\
2-E 13-14 \\
2-E 13-14 \\
2-E 13-14 \\
2-E 13-14 \\
2-E 13-14 \\
2-E 13-14 \\
2-E 13-14 \\
2-E 13-14 \\
2-E 13-14 \\
2-E 13-14 \\
2-E 13-14 \\
2-E 13-14\end{array}$ & 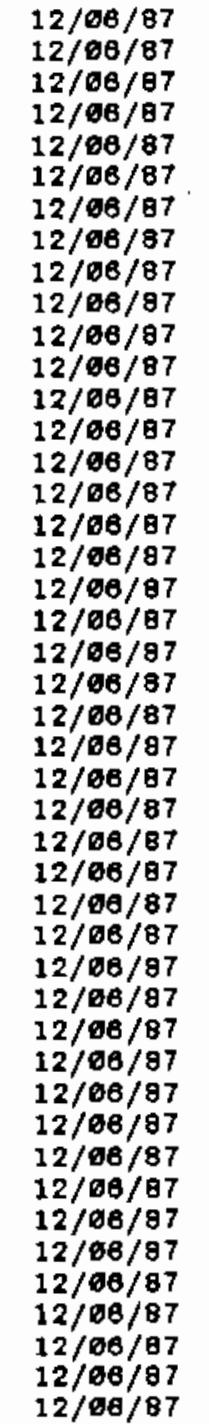 & 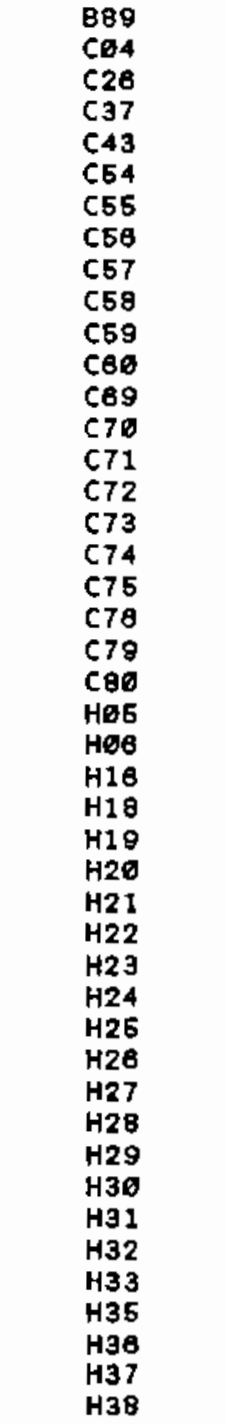 & $\begin{array}{l}\text { HEXCBEN } \\
\text { METACRY } \\
\text { PENTCHB } \\
\text { TETRCHB } \\
\text { TRICHLG } \\
\text { HEXACHL } \\
\text { NAPHTHA } \\
123 T R I \\
\text { PHENOL } \\
13 \text { ITRI } \\
1234 T E \\
1236 T E \\
\text { TOC } \\
\text { CYANIDE } \\
\text { FORMALN } \\
\text { NITRATE } \\
\text { SULFATE } \\
\text { FLUORID } \\
\text { CHLORID } \\
\text { PHOSPHA } \\
\text { KEROSEN } \\
\text { AMMONIU } \\
\text { ETHOXID } \\
\text { ETHMETH } \\
\text { TC } \\
\text { FZINC } \\
\text { FCALCIU } \\
\text { FBARIUM } \\
\text { FCAONIU } \\
\text { FCHRONI } \\
\text { FSILYER } \\
\text { FSODIUM } \\
\text { FNICKEL } \\
\text { FCOPPER } \\
\text { FYANADI } \\
\text { FALUMIN } \\
\text { FMANGAN } \\
\text { FPOTASS } \\
\text { FIRON } \\
\text { FMAGNES } \\
\text { FBERYLL } \\
\text { FSTRONT } \\
\text { FANTIXO } \\
\text { FARSENI } \\
\text { FMERCUR }\end{array}$ & $\begin{array}{l}< \\
< \\
< \\
< \\
< \\
< \\
< \\
< \\
< \\
< \\
< \\
< \\
<\end{array}$ & 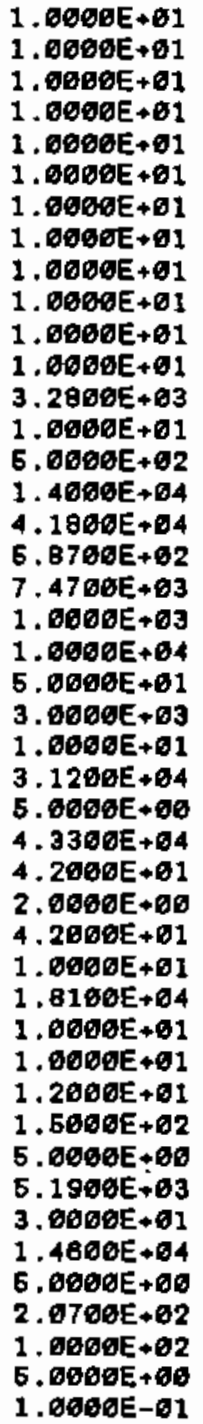 & $\begin{array}{l}P P B \\
P P B \\
P P B \\
P P B \\
P P B \\
P P B \\
P P B \\
P P B \\
P P B \\
P P B \\
P P B \\
P P B \\
P P B \\
P P B \\
P P B \\
P P B \\
P P B \\
P P B \\
P P B \\
P P B \\
P P B \\
P P B \\
P P B \\
P P B \\
P P B \\
P P B \\
P P B \\
P P B \\
P P B \\
P P B \\
P P B \\
P P B \\
P P B \\
P P B \\
P P B \\
P P B \\
P P B \\
P P B \\
P P B \\
P P B \\
P P B \\
P P B \\
P P B \\
P P B \\
P P B\end{array}$ \\
\hline
\end{tabular}


TABLE B.2. (contd)

\begin{tabular}{|c|c|c|c|c|c|c|}
\hline $\begin{array}{l}\text { WELL } \\
\text { NAME }\end{array}$ & $\begin{array}{c}\text { COLLECTION } \\
\text { DATE }\end{array}$ & $\begin{array}{c}\text { CONSTITUENT } \\
\text { CODE }\end{array}$ & $\begin{array}{l}\text { CONSTITUENT } \\
\text { NAWE }\end{array}$ & $\begin{array}{l}\text { LESS } \\
\text { THAN } \\
\text { FLAG }\end{array}$ & $\begin{array}{l}\text { ANALYSIS } \\
\text { VALUE }\end{array}$ & $\begin{array}{l}\text { ANALYSIS } \\
\text { UNITS }\end{array}$ \\
\hline $\begin{array}{l}2-E 13-14 \\
2-E 13-14 \\
2-E I 3-14 \\
2-E 13-14 \\
2-E 13-14 \\
2-E 13-14 \\
2-E 13-14 \\
2-E 13-14 \\
2-E 13-14 \\
2-E 13-14 \\
2-E 13-14 \\
2-E 13-14 \\
2-E 13-14 \\
2-E 13-14 \\
2-E 13-14 \\
2-E 13-14 \\
2-E 13-14 \\
2-E 13-14 \\
2-E 13-14 \\
2-E 13-14 \\
2-E 13-14 \\
2-E 13-14 \\
2-E 13-14 \\
2-E 13-14 \\
2-E 13-14 \\
2-E 13-14 \\
2-E 13-14 \\
2-E 13-14 \\
2-E 13-14 \\
2-E 13-14 \\
2-E 13-14 \\
2-E 13-14 \\
2-E 13-14 \\
2-E 13-14 \\
2-E 13-14 \\
2-E 13-14 \\
2-E 13-14 \\
2-E 13-14 \\
2-E 13-14 \\
2-E 13-14 \\
2-E 13-14 \\
2-E 13-14 \\
2-E 13-14 \\
2-E 13-14 \\
2-E 13-34\end{array}$ & $\begin{array}{l}12 / 0 \theta / 87 \\
12 / 06 / 87 \\
12 / 06 / 87 \\
12 / 86 / 87 \\
12 / 96 / 87 \\
12 / 08 / 87 \\
12 / 8 \theta / 87 \\
1 / 27 / 88 \\
1 / 27 / 8 \theta \\
1 / 27 / 88 \\
1 / 27 / 8 \theta \\
1 / 27 / 88 \\
1 / 27 / 8 \theta \\
1 / 27 / 88 \\
1 / 27 / 89 \\
1 / 27 / 88 \\
1 / 27 / 88 \\
1 / 27 / 8 \theta \\
1 / 27 / 88 \\
1 / 27 / 8 \theta \\
1 / 27 / 8 \theta \\
1 / 27 / 8 \theta \\
1 / 27 / 88 \\
1 / 27 / 88 \\
1 / 27 / 88 \\
1 / 27 / 88 \\
1 / 27 / 8 \theta \\
1 / 27 / 88 \\
1 / 27 / 88 \\
1 / 27 / 9 \theta \\
1 / 27 / 88 \\
1 / 27 / 88 \\
1 / 27 / 88 \\
1 / 27 / 88 \\
1 / 27 / 8 \theta \\
1 / 27 / 88 \\
1 / 27 / 88 \\
1 / 27 / 88 \\
1 / 27 / 88 \\
1 / 27 / 98 \\
1 / 27 / 88 \\
1 / 27 / 88 \\
1 / 27 / 8 \theta \\
1 / 27 / 88 \\
1 / 27 / 8 \theta\end{array}$ & 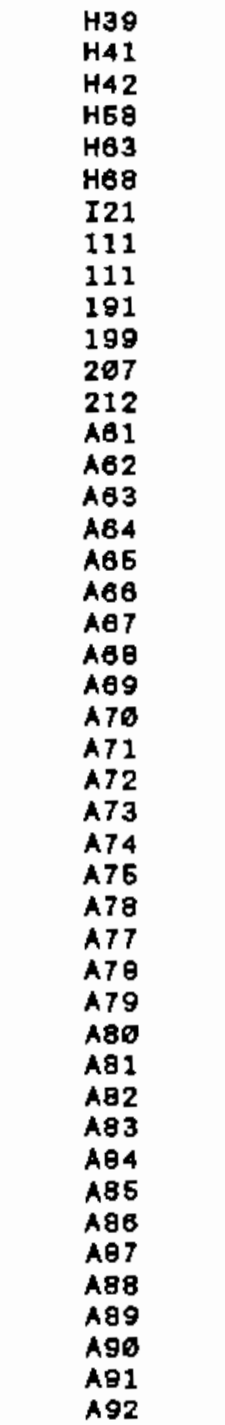 & 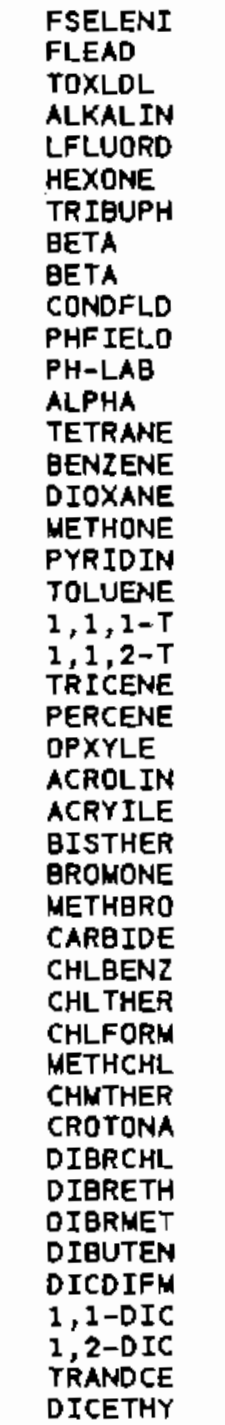 & $\begin{array}{l}< \\
< \\
< \\
< \\
< \\
< \\
< \\
< \\
< \\
< \\
< \\
< \\
< \\
< \\
< \\
< \\
< \\
< \\
< \\
< \\
< \\
< \\
< \\
< \\
< \\
< \\
< \\
< \\
< \\
<\end{array}$ & 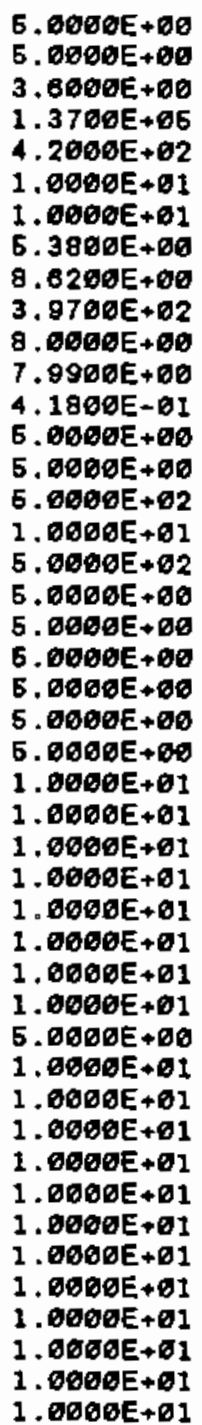 & 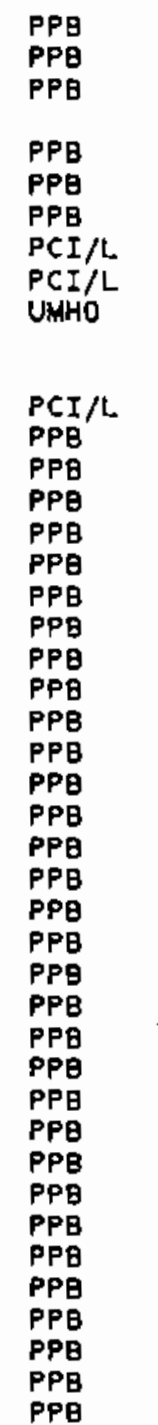 \\
\hline
\end{tabular}


IABLE B.2. (contd)

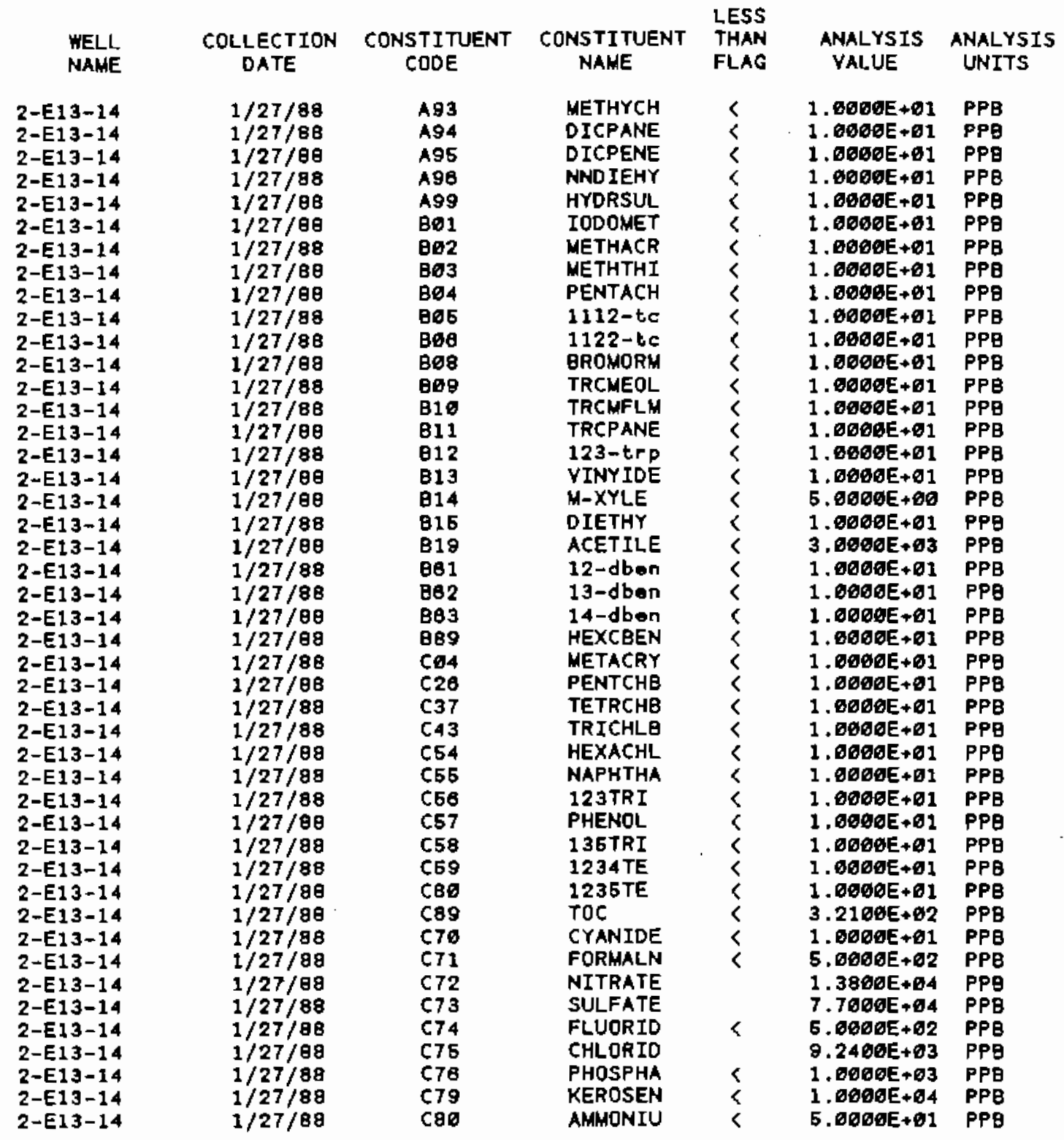


TABLE B.2. (contd)

\begin{tabular}{|c|c|c|c|c|c|c|}
\hline $\begin{array}{l}\text { WELL. } \\
\text { NAME }\end{array}$ & $\begin{array}{l}\text { COLLECTION } \\
\text { DATE }\end{array}$ & $\begin{array}{l}\text { CONSTI TUENT } \\
\text { CODE }\end{array}$ & $\begin{array}{l}\text { CONSTI TUENT } \\
\text { NAME }\end{array}$ & $\begin{array}{l}\text { LESS } \\
\text { THAN } \\
\text { FLAG }\end{array}$ & $\begin{array}{l}\text { ANALYSIS } \\
\text { VALUE }\end{array}$ & $\begin{array}{l}\text { ANALYSIS } \\
\text { UNITS }\end{array}$ \\
\hline $\begin{array}{l}2-E 13-14 \\
2-E 13-14 \\
2-E 13-14 \\
2-E 13-14 \\
2-E 13-14 \\
2-E 13-14 \\
2-E 13-14 \\
2-E 13-14 \\
2-E 13-14 \\
2-E 13-14 \\
2-E 13-14 \\
2-E 13-14 \\
2-E 13-14 \\
2-E 13-14 \\
2-E 13-14 \\
2-E 13-14 \\
2-E 13-14 \\
2-E 13-14 \\
2-E 13-14 \\
2-E 13-14 \\
2-E 13-14 \\
2-E 13-14 \\
2-E 13-14 \\
2-E 13-14 \\
2-E 13-14 \\
2-E 13-14 \\
2-E 13-14 \\
2-E 13-14 \\
2-E 13-14 \\
2-E 13-14 \\
2-E 13-14 \\
2-E 13-14 \\
2-E 13-14 \\
2-E 13-14 \\
2-E 13-14 \\
2-E 13-14 \\
2-E 13-14 \\
2-E 13-14 \\
2-E 13-14 \\
2-E 13-14 \\
2-E 13-14 \\
2-E 13-14 \\
2-E 13-14 \\
2-E 13-14 \\
2-E 13-14\end{array}$ & $\begin{array}{l}1 / 27 / 88 \\
1 / 27 / 88 \\
1 / 27 / 8 \theta \\
1 / 27 / 8 \theta \\
1 / 27 / 88 \\
1 / 27 / 8 \theta \\
1 / 27 / 88 \\
1 / 27 / 8 \theta \\
1 / 27 / \theta \theta \\
1 / 27 / 8 \theta \\
1 / 27 / 88 \\
1 / 27 / 8 \theta \\
1 / 27 / 88 \\
1 / 27 / \theta 8 \\
1 / 27 / 8 \theta \\
1 / 27 / 88 \\
1 / 27 / 8 \theta \\
1 / 27 / \theta 8 \\
1 / 27 / \theta 8 \\
1 / 27 / 88 \\
1 / 27 / 8 \theta \\
1 / 27 / 8 \theta \\
1 / 27 / 88 \\
1 / 27 / \theta \theta \\
1 / 27 / 8 \theta \\
1 / 27 / \theta 8 \\
1 / 27 / 8 \theta \\
1 / 27 / \theta 8 \\
1 / 27 / \theta 8 \\
1 / 27 / 88 \\
1 / 29 / 8 \theta \\
1 / 29 / 88 \\
1 / 29 / 8 \theta \\
1 / 29 / 8 \theta \\
1 / 29 / 8 \theta \\
1 / 29 / \theta 8 \\
1 / 29 / 8 \theta \\
1 / 29 / \theta 8 \\
4 / 19 / 88 \\
4 / 19 / 8 \theta \\
4 / 19 / 8 \theta \\
4 / 19 / 88 \\
4 / 19 / 88 \\
4 / 19 / 88 \\
4 / 19 / 8 \theta\end{array}$ & $\begin{array}{l}H ø 5 \\
H D 6 \\
H 1 \theta \\
H 18 \\
H 19 \\
H 2 \theta \\
H 21 \\
H 22 \\
H 23 \\
H 24 \\
H 26 \\
H 2 \theta \\
H 27 \\
H 28 \\
H 29 \\
H 3 \theta \\
H 31 \\
H 32 \\
H 33 \\
H 36 \\
H 3 \theta \\
H 37 \\
H 38 \\
H 39 \\
H 41 \\
H 42 \\
H 6 \theta \\
H \theta 3 \\
H 6 \theta \\
I 21 \\
010 \\
\theta 24 \\
034 \\
104 \\
108 \\
121 \\
197 \\
H \theta 6 \\
111 \\
111 \\
191 \\
199 \\
207 \\
212 \\
A \theta 1\end{array}$ & $\begin{array}{l}\text { ETHOXIO } \\
\text { ETHMETH } \\
\text { TC } \\
\text { FZINC } \\
\text { FCALCIU } \\
\text { FEARIUM } \\
\text { FCAONIU } \\
\text { FCHROMI } \\
\text { FSILVER } \\
\text { FSOOIUM } \\
\text { FNICKEL } \\
\text { FCOPPER } \\
\text { FVANADI } \\
\text { FALUNIN } \\
\text { FMANGAN } \\
\text { FPOTASS } \\
\text { FIRON } \\
\text { FNAGNES } \\
\text { FBERYLL } \\
\text { FSTRONT } \\
\text { FANTIMO } \\
\text { FARSENI } \\
\text { FMERCUR } \\
\text { FSELENI } \\
\text { FLEAD } \\
\text { TOXLDL } \\
\text { ALKALIN } \\
\text { LFLUORO } \\
\text { HEXONE } \\
\text { TRIEUPH } \\
\text { CO-OE } \\
\text { CS-137 } \\
\text { RU-1OE } \\
\text { U } \\
\text { TRITIUM } \\
\text { SR 9O } \\
\text { TC-99 } \\
\text { HNITRAT } \\
\text { BETA } \\
\text { BETA } \\
\text { CONOFLD } \\
\text { PHFIELD } \\
\text { PH-LAB } \\
\text { ALPHA } \\
\text { TETRANE }\end{array}$ & $\begin{array}{l}< \\
< \\
< \\
< \\
< \\
< \\
< \\
< \\
< \\
< \\
< \\
< \\
< \\
<\end{array}$ & 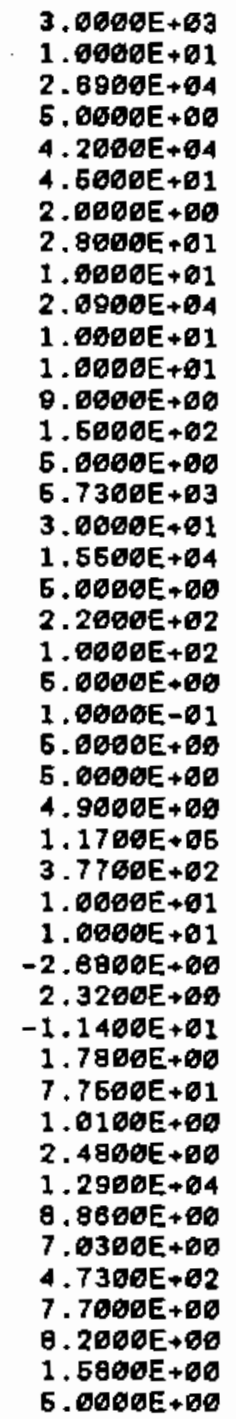 & 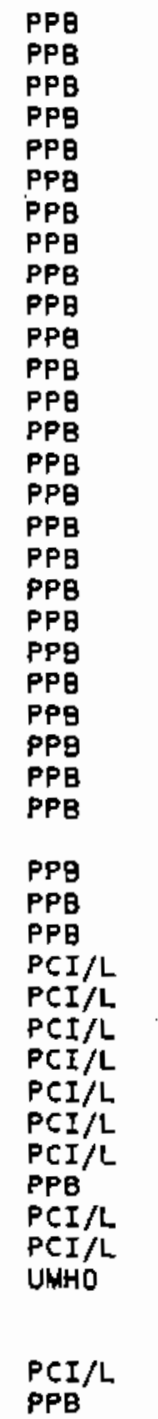 \\
\hline
\end{tabular}


TABLE B.2. (contd)

\begin{tabular}{|c|c|c|c|c|c|c|}
\hline $\begin{array}{l}\text { HELL } \\
\text { NAME }\end{array}$ & $\begin{array}{c}\text { COLLECTION } \\
\text { DATE }\end{array}$ & $\begin{array}{l}\text { CDNSTITUENT } \\
\text { CODE }\end{array}$ & $\begin{array}{l}\text { CONSTITUENT } \\
\text { NAME }\end{array}$ & $\begin{array}{l}\text { LESS } \\
\text { THAN } \\
\text { FLAG }\end{array}$ & $\begin{array}{l}\text { WNALYSIS } \\
\text { VALUE }\end{array}$ & $\begin{array}{l}\text { ANALYSIS } \\
\text { UNITS }\end{array}$ \\
\hline $\begin{array}{l}2-E 13-14 \\
2-E 13-14 \\
2-E 13-14 \\
2-E 13-14 \\
2-E 13-14 \\
2-E 13-14 \\
2-E 13-14 \\
2-E 13-14 \\
2-E 13-14 \\
2-E 13-14 \\
2-E 13-14 \\
2-E 13-14 \\
2-E 13-14 \\
2-E 13-14 \\
2-E 13-14 \\
2-E 13-14 \\
2-E 13-14 \\
2-E 13-14 \\
2-E 13-14 \\
2-E 13-14 \\
2-E 13-14 \\
2-E 13-14 \\
2-E 13-14 \\
2-E 13-14 \\
2-E 13-14 \\
2-E 13-14 \\
2-E 13-14 \\
2-E 13-14 \\
2-E 13-14 \\
2-E 13-14 \\
2-E 13-14 \\
2-E 13-14 \\
2-E 13-14 \\
2-E 13-14 \\
2-E 13-14 \\
2-E 13-14 \\
2-E 13-14 \\
2-E 13-14 \\
2-E 13-14 \\
2-E 13-14 \\
2-E 13-14 \\
2-E 13-14 \\
2-E 13-14 \\
2-E 13-14 \\
2-E 13-14\end{array}$ & $\begin{array}{l}4 / 19 / 88 \\
4 / 19 / 8 \theta \\
4 / 19 / 88 \\
4 / 19 / 8 \theta \\
4 / 19 / 88 \\
4 / 19 / 8 \theta \\
4 / 19 / 88 \\
4 / 19 / 8 B \\
4 / 19 / 8 \theta \\
4 / 19 / 8 \theta \\
4 / 19 / 8 \theta \\
4 / 19 / 8 \theta \\
4 / 19 / 8 \theta \\
4 / 19 / 88 \\
4 / 19 / 8 \theta \\
4 / 19 / 8 \theta \\
4 / 19 / 8 \theta \\
4 / 19 / 8 B \\
4 / 19 / 9 \theta \\
4 / 19 / 88 \\
4 / 19 / 8 \theta \\
4 / 19 / 8 \theta \\
4 / 19 / 8 \theta \\
4 / 19 / 8 \theta \\
4 / 19 / 8 \theta \\
4 / 19 / 88 \\
4 / 19 / 8 \theta \\
4 / 19 / 8 \theta \\
4 / 19 / 8 \theta \\
4 / 19 / 8 \theta \\
4 / 19 / 88 \\
4 / 19 / \theta \theta \\
4 / 19 / 88 \\
4 / 19 / 8 \theta \\
4 / 19 / 88 \\
4 / 19 / 8 \theta \\
4 / 19 / 8 \theta \\
4 / 18 / 88 \\
4 / 19 / 8 \theta \\
4 / 19 / 88 \\
4 / 19 / 8 \theta \\
4 / 19 / 88 \\
4 / 19 / 8 \theta \\
4 / 19 / 8 \theta \\
4 / 19 / 88\end{array}$ & 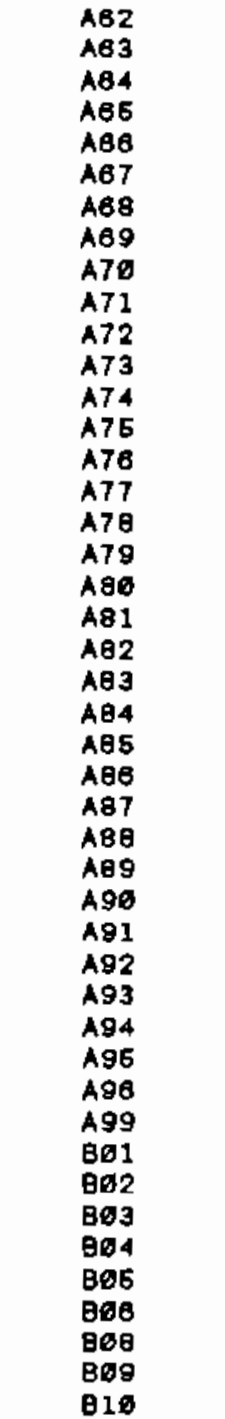 & $\begin{array}{l}\text { EENZENE } \\
\text { DIOXANE } \\
\text { METHONE } \\
\text { PYRIDIN } \\
\text { TOLUENE } \\
1,1,1-T \\
1,1,2-T \\
\text { TRICENE } \\
\text { PERCENE } \\
\text { OPXYLE } \\
\text { ACROLIN } \\
\text { ACRYILE } \\
\text { OISTHER } \\
\text { BROMONE } \\
\text { METHERO } \\
\text { CAREIDE } \\
\text { CHLBENZ } \\
\text { CHLTHER } \\
\text { CHLFORM } \\
\text { METHCHL } \\
\text { CHMTHER } \\
\text { CROTONA } \\
\text { OIBRCHL } \\
\text { DIBRETH } \\
\text { DIBRNET } \\
\text { DIBUTEN } \\
\text { DICOIFM } \\
1,1-D I C \\
1 \text { I-DIC } \\
\text { TRANDCE } \\
\text { DICETHY } \\
\text { METHYCH } \\
\text { OICPANE } \\
\text { DICPENE } \\
\text { NNOIEHY } \\
\text { HYDRSUL } \\
\text { IODOMEY } \\
\text { METHACR } \\
\text { METHTHI } \\
\text { PENTACH } \\
1112-t C \\
\text { I I22- TC } \\
\text { ERONORM } \\
\text { TRCHEOL } \\
\text { TRCMFLH }\end{array}$ & 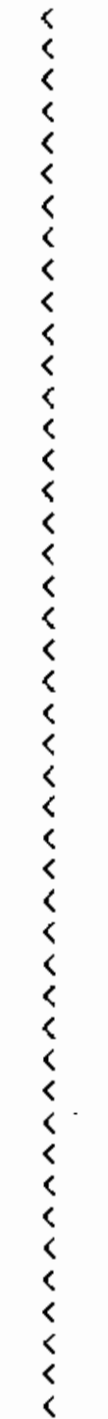 & 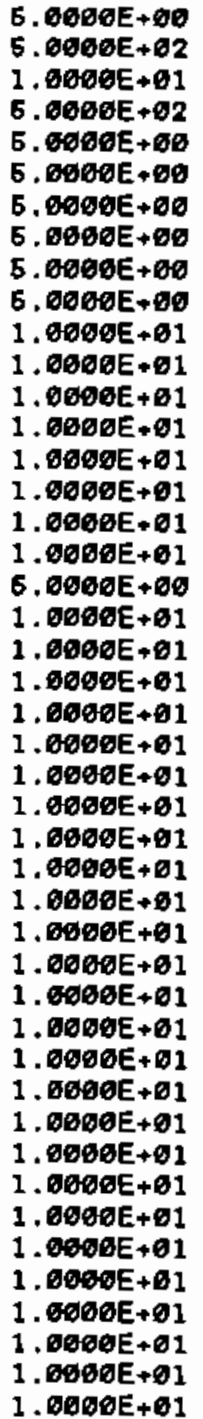 & $\begin{array}{l}P P B \\
P P B \\
P P B \\
P P B \\
P P B \\
P P B \\
P P B \\
P P B \\
P P B \\
P P B \\
P P B \\
P P B \\
P P B \\
P P B \\
P P B \\
P P B \\
P P B \\
P P B \\
P P B \\
P P B \\
P P B \\
P P B \\
P P B \\
P P B \\
P P B \\
P P B \\
P P B \\
P P B \\
P P B \\
P P B \\
P P B \\
P P B \\
P P B \\
P P B \\
P P B \\
P P B \\
P P B \\
P P B \\
P P B \\
P P B \\
P P B \\
P P B \\
P P B \\
P P B \\
P P B\end{array}$ \\
\hline
\end{tabular}


TABLE B.2. (contd)

\begin{tabular}{|c|c|c|c|c|c|c|}
\hline $\begin{array}{l}\text { WELL (a) } \\
\text { NAME }\end{array}$ & $\begin{array}{c}\text { COLLECTION } \\
\text { DATE }\end{array}$ & $\begin{array}{l}\text { CONSTITUENT } \\
\text { CODE }\end{array}$ & $\begin{array}{l}\text { CONST I TUENT } \\
\text { NAME }\end{array}$ & $\begin{array}{l}\text { LESS } \\
\text { THAN } \\
\text { FLAG }\end{array}$ & $\begin{array}{l}\text { ANALYSIS } \\
\text { VALUE }\end{array}$ & $\begin{array}{l}\text { ANALYSIS } \\
\text { UNITS }\end{array}$ \\
\hline $\begin{array}{l}2-E 13-14 \\
2-E 13-14 \\
2-E 13-14 \\
2-E 13-14 \\
2-E 13-14 \\
2-E 13-14 \\
2-E 13-14 \\
2-E 13-14 \\
2-E 13-14 \\
2-E 13-14 \\
2-E 13-14 \\
2-E 13-14 \\
2-E 13-14 \\
2-E 13-14 \\
2-E 13-14 \\
2-E 13-14 \\
2-E 13-14 \\
2-E 13-14 \\
2-E 13-14 \\
2-E 13-14 \\
2-E 13-14 \\
2-E 13-14 \\
2-E 13-14 \\
2-E 13-14 \\
2-E 13-14 \\
2-E 23-2 \\
2-E 23-2 \\
2-E 23-2 \\
2-E 23-2 \\
2-E 23-2 \\
2-E 23-2 \\
2-E 23-2 \\
2-E 23-2 \\
2-E 23-2\end{array}$ & $\begin{array}{r}4 / 19 / 8 \theta \\
4 / 19 / 88 \\
4 / 19 / 8 \theta \\
4 / 19 / \theta \theta \\
4 / 19 / 88 \\
4 / 19 / \theta 8 \\
4 / 19 / \theta \theta \\
4 / 19 / 8 \theta \\
4 / 19 / 88 \\
4 / 19 / 89 \\
4 / 19 / \theta \theta \\
4 / 19 / 88 \\
4 / 19 / 88 \\
4 / 19 / \theta \theta \\
4 / 19 / 8 \theta \\
4 / 19 / 88 \\
4 / 19 / 88 \\
4 / 19 / 88 \\
4 / 19 / 8 \theta \\
4 / 19 / 88 \\
4 / 19 / 88 \\
4 / 19 / 88 \\
4 / 19 / 8 \theta \\
4 / 19 / 88 \\
4 / 19 / 88 \\
19 / 29 / 86 \\
10 / 29 / 86 \\
10 / 29 / 86 \\
3 / 27 / 87 \\
3 / 27 / \theta 7 \\
3 / 27 / \theta 7 \\
6 / 29 / 87 \\
6 / 29 / 87 \\
6 / 29 / \theta 7\end{array}$ & $\begin{array}{l}B 11 \\
B 12 \\
B 13 \\
B 14 \\
B 15 \\
B 19 \\
C \theta 4 \\
C 69 \\
C 71 \\
C 72 \\
C 73 \\
C 74 \\
C 75 \\
C 76 \\
C 86 \\
H 95 \\
H 68 \\
H 18 \\
H 37 \\
H 38 \\
H 39 \\
H 41 \\
H 5 B \\
H \theta 3 \\
H 8 B \\
19 \theta \\
111 \\
C 72 \\
108 \\
111 \\
C 72 \\
108 \\
111 \\
H 65\end{array}$ & $\begin{array}{l}\text { TRCPANE } \\
123-\text { tIP } \\
\text { VINYIDE } \\
\text { M-XYLE } \\
\text { OIETHY } \\
\text { ACETILE } \\
\text { METACRY } \\
\text { TOC } \\
\text { FORMALN } \\
\text { NITRATE } \\
\text { SULFATE } \\
\text { FLUORIO } \\
\text { CHLORID } \\
\text { PHOSPHA } \\
\text { AMMONIU } \\
\text { ETHOXIO } \\
\text { ETHMETH } \\
\text { TC } \\
\text { FARSENI } \\
\text { FMERCUR } \\
\text { FSELENI } \\
\text { FLEAD } \\
\text { ALKALIN } \\
\text { LFLUORO } \\
\text { HEXONE } \\
\text { TRITIUM } \\
\text { BETA } \\
\text { NITRATE } \\
\text { TRITIUN } \\
\text { EETA } \\
\text { NITRATE } \\
\text { TRITIUM } \\
\text { BETA } \\
\text { HNITRAT }\end{array}$ & $\begin{array}{l}< \\
< \\
< \\
< \\
< \\
< \\
< \\
<\end{array}$ & 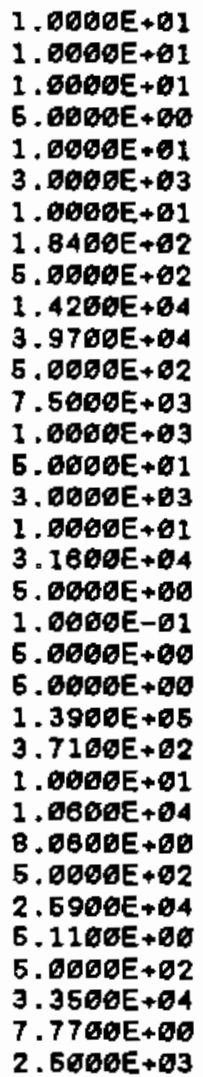 & $\begin{array}{l}\text { PPB } \\
\text { PPB } \\
\text { PPB } \\
\text { PPB } \\
\text { PPB } \\
\text { PPB } \\
\text { PPB } \\
\text { PPB } \\
\text { PPB } \\
\text { PPB } \\
\text { PPB } \\
\text { PPB } \\
\text { PPB } \\
\text { PPB } \\
\text { PPB } \\
\text { PPB } \\
\text { PPB } \\
\text { PPB } \\
\text { PPB } \\
\text { PPB } \\
\text { PPB } \\
\text { PPB } \\
\text { PPB } \\
\text { PPB } \\
\text { PCI } / L \\
\text { PCI } / L \\
\text { PPB } \\
P C I / L \\
\text { PCI } / L \\
\text { PPB } \\
\text { PCI } / L \\
\text { PCI } / L \\
\text { PPB }\end{array}$ \\
\hline
\end{tabular}

(a) All wells prefixed by $299-$. 


\section{APPENDIX $C$}

FUNCIIONAL DESIGN AND CONSTRUCTION STANDARDS FOR GROUND-WATER MONITORING WELLS 


\section{APPENDIX C}

\section{FUNCTIONAL DESIGN AND CONSTRUCTION STANDARDS FOR \\ GROUND-WATER MONITORING WELLS}

\section{INTRODUCTION}

Four ground-water monitoring wells will be drilled near the 2101-M pond to fulfill the objectives of the detection-level monitoring plan. Well locations are considered tentative until underground and overhead utilities are checked by Westinghouse Hanford Company personnel before drilling. Single-completion shallow wells will be installed at each location. The well depths will be approximately $332 \mathrm{ft}$ below ground surface. A summary of locations estimated and dimensions of the wells is presented in Table C.1.

TABLE C.1. Planned Well Locations and Depths for the 2101-M Pond

\begin{tabular}{|c|c|c|c|c|}
\hline Type of we!l & $\begin{array}{c}\text { Approxieate } \\
\text { Location } \\
\text { (Hanford Coord.) }\end{array}$ & $\begin{array}{l}\text { Approximate } \\
\text { Depth to } \\
\text { Vater (ft) }\end{array}$ & $\begin{array}{l}\text { Approxinate } \\
\text { Depth of } \\
\text { Boreholo (ft) }\end{array}$ & $\begin{array}{l}\text { Length of } \\
\text { Screen (ft) }\end{array}$ \\
\hline Shallow Uonitoring & $\begin{array}{l}\text { N } 38529 \\
\text { I } 54425\end{array}$ & 315 & 332 & 20 \\
\hline Shallow Uonitoring & $\begin{array}{l}\text { N } 38775 \\
\text { N } 54155\end{array}$ & 315 & 332 & 26 \\
\hline Shallow Wontoring & $\begin{array}{l}\text { N } 38725 \\
\text { I } 54625\end{array}$ & 315 & 332 & 28 \\
\hline Shallow Uonitoring & $\begin{array}{l}N 38858 \\
\text { N } 54925\end{array}$ & $3 t 5$ & 332 & 29 \\
\hline
\end{tabular}

The purpose of this appendix is to discuss the minimum design, construction, and testing standards required to meet the objectives of detection-level monitoring. Four tasks are discussed:

- Task 1. Drilling

- Task 2. Geologic sampling

- Task 3. Well construction

- Task 4. Hydrologic testing. 
TASK 1. DRILLING

A cable-tool drill rig is the recommended drilling method. Temporary steel casing will be driven concurrent with drilling, because most of the geologic formations are expected to be uncemented and unconsolidated. Hard tool may be used for drilling through gravel, boulders, and cobbles and once the water table is reached, otherwise core barrel drilling is preferred. A split-tube sampler may be used to take relatively undisturbed samples of specific layers when necessary.

Fittings may be greased and fluids carefully added to the drill rig before cleaning. Petroleum- and synthetic-based lubricants shall not be used on the drilling and sampling tools or fittings. Only Teflon (TFE) lubricants such as Chevron Poly FM grease, "Green Stuff" (manufactured by King 0il Tools, Inc.), or a pure vegetable oil will be permitted. Precaution should be taken to prevent contamination of the well with oil and grease.

\section{Borehole Size}

The minimum borehole diameter will be 8 in. Telescoping of successively smaller casings will be required in each well to achieve a minimum 8-in.-dia. borehole, prevent hydraulic interconnection through any confining layers, and prevent problems in pulling the casing. The cable-tool driller will begin the boreholes with 10-in.-dia. schedule 40, carbon steel casing conforming to American Society for Testing and Materials (ASTM) A53 Grade B or API 5L Grade B (ASTM 1986). After drilling and driving to the appropriate depth, 8-in.-dia. casing will be telescoped inside, and drilling will continue to the desired total depth.

If perched water is encountered, special precautions will be taken to prevent contamination migration. In no instance shall any one size of temporary casing be extended across the entire thickness of a confining layer, because this may connect two aquifers or a perched zone of water to the ground water. The uppermost casing shall not penetrate less than $2 \mathrm{ft}$ nor more than $5 \mathrm{ft}$ or $20 \%$ of the known thickness of the confining unit. The smaller casing shall be telescoped through the remainder of the confining layer into the next permeable unit. Bentonite slurry will be added to the annulus while drilling through the confining layer to form a seal. 


\section{Qualification of Drillers}

Orillers should have at least 5 years' experience as a driller and be licensed in the state of Washington. Drillers should have a minimum of 2 years' experience specifically in cable-tool drilling. At least 1 year of this experience should be as a driller, not as a helper or a derrick man. The cable-tool drillers should have specific experience for underreaming and pulling casing. In addition, the drillers should have extensive experience installing monitoring wells for hazardous waste investigations. In accordance with Occupational Safety and Health Act (OSHA) regulations (29 CFR Part 1910.120), the drilling company that is contracted must meet OSHA medical, monitoring, and hazardous waste training requirements.

\section{Equipment}

The drilling contractor will provide all equipment required to successfully complete all tasks outlined in the detailed drilling specifications. Equipment will be in good working order and steam cleaned just before arriving onsite. Equipment failure is the responsibility of the contractor, and any time lost because of equipment failure will constitute downtime.

\section{Temporary Materials}

All temporary casing should be clean, undamaged sections of carbon steel pipe. The sizes that may be required are 10 and 8 in. Casing should be Schedule 40 and meet ASTM specification A53 Grade B or API 5L Grade B (ASTM 1986) .

The temporary continuous-slot telescoping well screens to be used for aquifer testing will be constructed of type 304 or 316 stainless steel and shall be a nominal 8-in. dia. These screens will have a flat stainless steel plate and bajler hook welded to the bottom. Temporary screens will remain in place after the aquifer tests and the monitoring wells completed at the desired depth within the temporary screen.

\section{Welding}

Because retrieval of temporary casing may be difficult, precautions will be taken to help maintain high-integrity welds (i.e., beveling cuts before welding, grinding, and crushing to remove slag between passes). Welds should 
not be ground flush to the casing. An extra bead should be considered on welds near the top of the casing string. The contractor will be responsible for broken welds.

\section{Drill Cuttings and Water Disposal}

Cuttings and drill-water bailed or cored from the hole will be surveyed periodically with radiation and organic-vapor-detection monitoring instruments. Materials with any contamination above prescribed action levels will be stored onsite until the proper disposal method is identified. Uncontaminated soil and water will be disposed of in the vicinity of the borehole.

\section{TASK 2. GEOLOGIC SAMPLING}

The drilling contractor will be responsible for proper operation of the equipment to be used both for the sediment sample collection and for the aquifer tests. Sediment samples will be collected at a minimum of 5 - $\mathrm{ft}$ intervals during installation of the well. Samples will be collected using a core barrel where possible or with a dart bailer when using the hard tool method. Samples collected for chemical analysis should be collected with the core-barrel method.

\section{IASK 3. WELL CONSTRUCTION}

A generic diagram of the planned well construction is presented in Figure C.1. This type of well construction represents the state of the art in groundwater monitoring and exceeds all Washington State Department of Ecology (hereafter called Ecology) minimum standards for well construction given in WAC-173-16D.

\section{CONSTRUCTION MATERIALS}

This section describes the types of materials required for construction of a monitoring well meeting federal and state regulations.

\section{Stainless Steel Screens and Casing}

The wells should be constructed of 4-in.-diameter, flush-threaded stainless steel well screen and pipe. The monitoring well casing will be Schedule 5S, meeting ASTM specification A312 or A778 (ASTM 1986). The end 


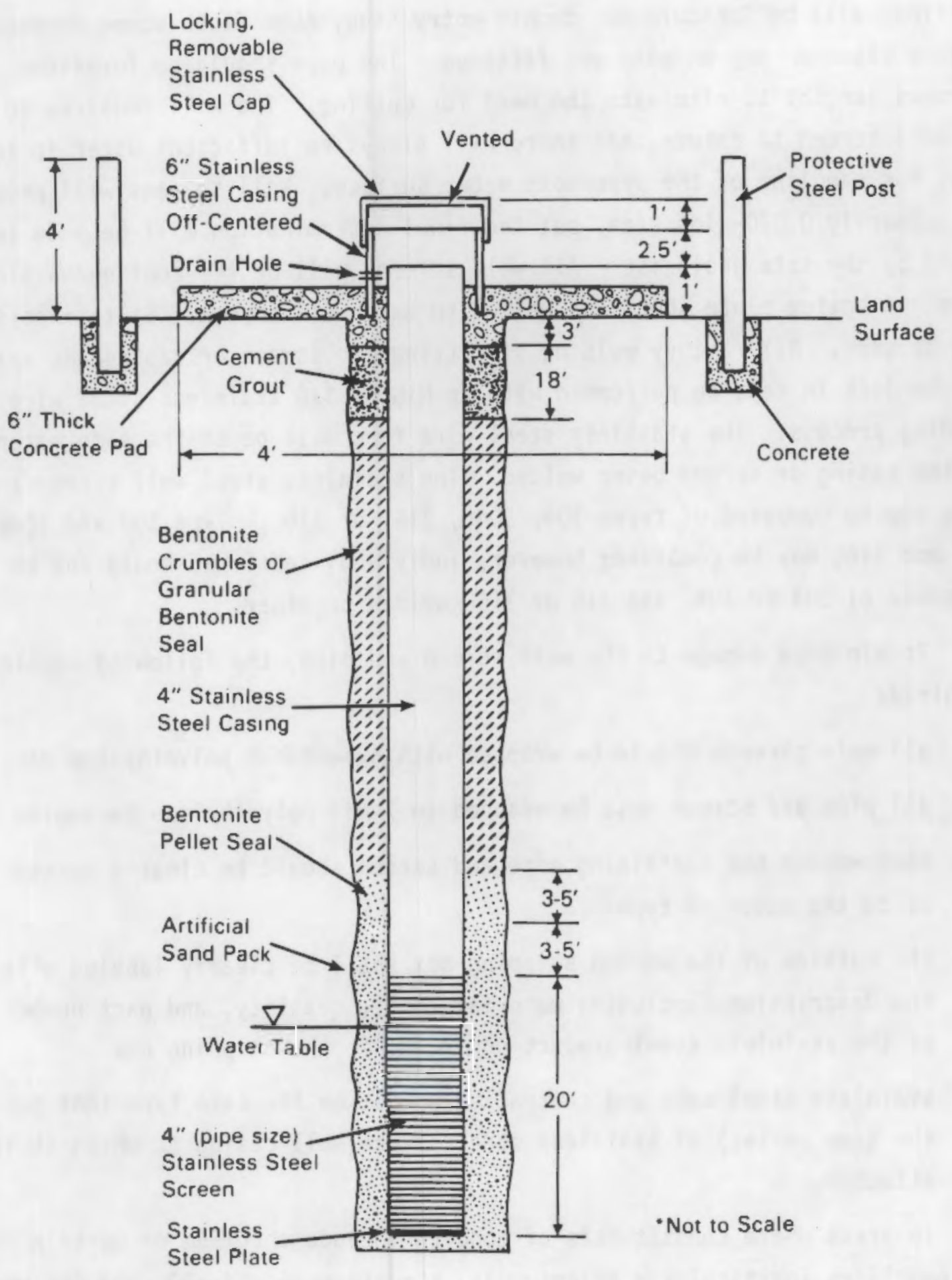

FIGURE C.1. Schematic Diagram of Monitoring Well 
fittings will be Schedule 40, double entry Stub, ACME flush screw threads with a Viton o-ring on male end fittings. The pipe should be furnished in various lengths to eliminate the need for cutting. The well requires $20 \mathrm{ft}$ of well screen to ensure that there will always be sufficient water in the well for sampling of the uppermost water surface. Well screens will probably be primarily 0.020 -slot size, but the final determination will be made in the field by the site geologist. All well screens will be the continuous slot type. A bottom plate should be welded to each well screen. Silt traps should not be used. All factory welding of fittings to screen or casing and welding to the lock in caps be performed with an MIG or TIG stainless steel wire feed welding process. The stainless steel wire feed must be of the same material as the casing or screen being welded. The stainless steel well screen and pipe may be composed of types $304,304 \mathrm{~L}, 316$, or $316 \mathrm{~L}$. Type 304 and $304 \mathrm{~L}$ or 316 and $316 \mathrm{~L}$ may be combined; however, individual sections should not be composed of 304 or $304 \mathrm{~L}$ and 316 or $316 \mathrm{~L}$ welded together.

To minimize damage to the well screen and pipe, the following should be required:

- all male threads should be wrapped with expandable polyethylene mesh

- all pipe and screen must be wrapped in 7-mil polyethylene packaging

- each wooden box containing pipe and screen should be clearly marked as to the material type

- the outside of the wooden shipping box shall be clearly labeled with the description (including material type), quantity, and part number of the stainless steel product contained in the shipping box

- stainless steel caps and centralizers must be the same type (not just the same series) of stainless steel as the well casing to which it is attached.

In areas where constituents of concern include chromium or certain radionuclides (particularly selenium-75, strontium-85 and -90 , and cesium-137), the corrosion-resistant stainless steel should be passivated by the manufacturer or supplier to prevent the release of chromium from the well screen and pipe or adsorption of constituents (Raber, Garrison, and Oversby 1983). Passivation is also needed for cathodic protection in high chloride or fluoride

$$
\text { C. } 6
$$


environments (e.g., areas where large amounts of hydrochloric acid (HCL) have been released into the ground water). Pretreatment used before the passivation shall be in accordance with Mil-spec-5002; shall leave the surface of the pipe and screen free of oil, grease, rust, scale, and other foreign matter, and shall have no deleterious effect on the material properties. The stainless steel parts shall be passivated in accordance with Mil-spec QQ-P-35B.

Specifically, these parts shall be immersed in an aqueous solution of 38 to $42 \%$ nitric acid, by volume, in accordance with $0-\mathrm{N}-350$, and 2 to $3 \%$ sodium dichromate, by weight, in accordance with 0-5-595. The materials should be immersed in the solution at 70 to $120^{\circ} \mathrm{F}$ for 25 to $30 \mathrm{~min}$, to be followed by a clean rinse and an immersion in a 4 to $6 \%$ sodium dichromate solution for 30 min. The materials should then be rinsed a final time in clean water and air dried.

The stainless steel casing, well screen, and accessories (caps, centralizers, etc.) must conform to all applicable items in the above specifications with all supporting test data certified, submitted to, and approved by Pacific Northwest Laboratory (PNL) and the drilling contractor, before shipment.

\section{Filter Pack}

Because the rate at which sand grains will settle in water is controlled by particle size and shape, it is desirable to obtain a filter pack that consists of sand grains that are uniform in shape and size. The particle size of the sand pack should be of a size that will prevent sediment from the formation entering the screen in large quantities. Generally, the smallest particles should be slightly larger than the slot size of the screen, if the particles are too large, finer-grained sediments could still enter the screen through the pack. The filter pack surrounding the well screen should consist of kiln-dried, rounded, and spherical grains of sand composed of at least $96 \%$ quartz. The sand grains shall be composed of subrounded to rounded grains; that is, at least $90 \%$ of the grains shall have a Powers roundness of 3.0 to 6.0 , or a Krumbein roundness of 0.6 to 1.0. The maximum projection sphericity (Sneed and Folk 1958) shall be 0.6 to 1.0 . The sand particles should be very uniform in size. Specifically, the uniformity coefficient should be equal to or less than 2.0. The effective size shall be proportional to the sieve size. For example, the 10 to 20 U.S. mesh size shall have an effective size of 0.033 
to 0.045 in. ( 1.0 to $1.2 \mathrm{~mm})$, and the 8 to 12 U.S. mesh size shall have an effective size of 0.067 to $0.079 \mathrm{in}$. (1.7 to $2.0 \mathrm{~mm})$. The paper sacks containing the sand should have polyethylene liners to prevent contamination and water damage. The two currently approved supply sources for the quartz sand pack are the Fountain Sand and Gravel Company, Pueblo, Colorado, and the Colorado Silica Sand, Inc., Colorado Springs, Colorado.

Secondary Filter Pack (Optional)

A secondary filter is often desirable and is mandatory if a bentonite slurry is to be placed above the sand pack rather than a seal of pellets, crumbles, or granules. A secondary filter is a 1 - to $2-\mathrm{ft}$ layer of material that is placed in the annular space between the filter pack and the bentonite seal or between the bentonite seal and the grout. Unilike the filter pack, which is very uniform in size, the secondary filter above the sand pack should be less uniform. The greater variation in size will allow the coarser grained sand fraction of the secondary filter to settle first on equivalently coarse sand pack and second on progressively finer-grained sand. Thus, the finest sand particles are adjacent to the overlying fine-grained bentonite slurry or crumbles. This prevents migration of the bentonite into the filter pack. A properly graded secondary filter shall consist of two particle sizes of sand including: 20 to 40 mesh [effective particle size of 0.016 to 0.019 in. (0.4 to $0.5 \mathrm{~mm})$ ] and 40 to 140 mesh, commonly called 100 mesh [effective particle size of 0.0055 to $0.0066 \mathrm{in}$. $(0.14$ to $0.17 \mathrm{~mm})]$. The sand materials shall be packaged in sacks with polyethylene liners to prevent contamination and water damage.

\section{Bentonite Sealants}

Bentonite pellet seals shall be composed of commercially available pellets that have a dry bulk density of at least $80 \mathrm{lb} / \mathrm{ft}^{3}$ and are a nominal 0.25 to $0.375 \mathrm{in}$. in diameter.

Granular bentonite shall be composed of coarse, granular bentonite crumbles, 8 to 20 U.S. sieve size. The sacks of bentonite shall be shipped on pallets and sealed with plastic sheeting.

The bentonite grout shall be a bentonite clay grout powder with a specific gravity of 2.5, a dry bulk density of $55 \mathrm{lb} / \mathrm{ft}^{3}$ and a $\mathrm{pH}$ of 9 to 10.5 . The 
bentonite grout powder shall be volclay grout (or an approved equal) below the water table and regular bentonite powder and/or granules above the water table. The sacks of bentonite shall be shipped on pallets and sealed with plastic sheeting. Water from an approved source shall be mixed with these powders or granules to form thick, bentonite slurries. When used, slurry seals shall have a thick, batter-like consistency with a Marsh Funnel viscosity of at least $100 \mathrm{sec}$. Volclay grout should maintain a weight of 94.3 to $94.5 \mathrm{Ibs} / \mathrm{ft}^{3}$. Maximum placement thickness of a slurry seal in a single lift should be $25 \mathrm{ft}$.

Cement Grout

Cement grout should consist of a mixture of Portland cement (ASTM C150; ASTM 1986) and water in the proportion of 5 to $6 \mathrm{gal}$ of clean water per bag (94 lbs or $1 \mathrm{ft}^{3}$ ) of cement. Because the volumetric shrinkage is about $17 \%$, an additive should be added to the cement to cause it to expand on setting, thus providing a tighter seal (Aherns 1970). The two primary choices are aluminum powder (1\%) and gypsum ( 3 to $6 \%$ ). Both additives also accelerate setting, but aluminum powder produces a stronger grout and is less expensive than gypsum.

Concrete Pad and Seal

Concrete, when used in monitoring well construction, shall be composed of either premixed, bagged concrete, or a mix of six sacks of cement per cubic yard. Except for an air-entraining agent, neither additives nor borehole cuttings shall be mixed with the concrete. With the addition of water, the maximum slump should be 6 in. The concrete should be steel reinforced. The stee 1 will be of sufficient size, configuration, and placement to minimize damage to the pad during normal use for its expected lifetime.

\section{Guard Posts}

Protective steel posts should be composed of carbon steel casing that is new, free from pits or breaks, and has a 4-in. nominal diameter. The pipe shall be Schedule 40 meeting ASTM specification A120 (ASTM 1986). The individual $6-\mathrm{ft}$ segments shall have straight, beveled cuts. The posts should be painted yellow to make them easily visible. 


\section{INSTALLATION PROCEDURES}

This section provides general information on how the final casing, screen, and annular materials should be installed in the well.

Stainless Steel Casing and Screen

The stainless steel well screen and casing is lowered to the desired depth and suspended in position until the sand pack has been implaced. Centralizers should be attached immediately above the well screen and at the appropriate distances along the length of the casing necessary to assure an adequate seal.

\section{Filter Pack}

The volume of the filter pack required to fill the annular space between the well screen and the well hole must be computed and carefully measured. The filter pack should be extended at least $1 \mathrm{ft}$ above the top of the screen for every $3 \mathrm{ft}$ of screen length, up to a maximum of $5 \mathrm{ft}$ above the top of the screen. While suspending the riser pipe, the temporary casing should be carefully withdrawn until the lowermost point on the casing is just below the top of the filter packed portion of the hole; this may be accomplished in increments, if necessary.

\section{Secondary Filter Pack}

To prevent downward migration of a bentonite slurry into the sand pack, a carefully measured volume of secondary filter sand should be placed above the top of the primary filter pack. This filter material is poured into the annular space through a clean, flush-threaded, tremie pipe that has been lowered to no more than $20 \mathrm{ft}$ above the placement interval. If used, the secondary filter should be 1 to $2 \mathrm{ft}$ thick. Where conditions warrant, the secondary filter may be eliminated.

\section{Bentonite Seal}

Where a bentonite seal is required above the water table and the pellet seal, bentonite granules or crumbles shall be used to seal the annular space to within $21 \mathrm{ft}$ below land surface. Pellets or crumbles should be dropped into the annulus slowly and measured frequently to ensure that the bentonite particles are not bridging. The use of volclay grout will be limited 
exclusively to placing the grout through a tremie in annular spaces below the water table. Bentonite slurry shall be pumped under pressure through a tremie pipe into the annulus. The opening of the tremie pipe should be immediately above the filter pack or point of placement. The end of the tremie pipe must be equipped with a side discharge to prevent displacement of the filter pack and seal materials. A minimum of $2 \mathrm{ft}$ of sealant material (sand, pellets, grout slurries, etc.) will be maintained in the annulus during placement. It is recommended that no more than $5 \mathrm{ft}$ of sand pack, $2 \mathrm{ft}$ of bentonite pellets or crumbles, or $20 \mathrm{ft}$ of bentonite or grout be installed before the casing is pulled back. The grout shall be a mixture of Volclay bentonite-based grout (dry mix) and water and shall have a mud balance weight between 9.3 to $9.5 \mathrm{lbs} / \mathrm{gal}$.

Cement Grout Surface Seal

The cement grout slurry with $1 \%$ aluminum powder will be added into the open annulus from $21 \mathrm{ft}$ below ground surface to within $3 \mathrm{ft}$ of land surface. If the grout settles, additional grout will have to be added to refill the annulus to within $3 \mathrm{ft}$ of the ground surface.

\section{Concrete}

The concrete mix for the surface well seal and pad shall be superior in strength and resistant to freezing and thawing. The concrete surface structure shall be placed within the annular space from a depth of $3 \mathrm{ft}$ and extend to the ground surface. This same concrete mix shall be used to construct a 4-ft by 4-ft by 6-in. concrete pad around and centered on the well. All exposed edges should be beveled at least 0.5 in. A brass marker shall be placed in the concrete before it sets. Numbers should not be stamped into the brass marker for at least 7 days after the concrete has been placed.

\section{Guard Posts}

At least three steel guard posts shall be placed at the corners of the pad and $4 \mathrm{ft}$ away from the well. Two of the posts shall be set in concrete to $2.5 \mathrm{ft}$ in depth. The third post should be set in a sleeve to allow easy removal of the post for equipment access to the well. 


\section{Quality Assurance}

The reliability of ground-water samples analyzed for hazardous constituents are known to be affected by drilling methods and equipment used. The following quality assurance procedures will be followed:

1. AlI equipment in contact with earthen materials or borehole fluids shall be steam cleaned (high pressure at $80 \mathrm{psi}$ and high temperature at $180^{\circ} \mathrm{F}$ is also acceptable) between each borehole. The contractor shall supply the equipment necessary for this decontamination. Tools and sampling equipment (e.g., split-spoon sampler, submersible pumps) to be used for soil sampling or aquifer testing shall be decontaminated by wiping or scrubbing off visible particulate matter; washing with a laboratorygrade detergent (e.g., trisodium phosphate); ciean water and methanol (technical grade or better) rinsing; and final rinsing with clean water free of oils and contaminants of concern. The trisodium phosphate, methanol (where necessary), distilled water, and all other items (e.g., brushes, clean water, etc.) must be provided and obtained by the contractor.

2. The soil around the borehole is a potential contamination source; therefore, all materials (casings, drill rods, etc.) will be stored on stands, pallets, support vehicles, etc.

3. Only preapproved lubricants, such as "Green Stuff, "will be allowed on any drilling tools. No petroleum-based lubricants will be used.

4. Any water used during drilling will be obtained from a designated source. No drifling additives (i.e., drill foam) will be used unless approved by the site geologist.

5. All monitoring well pipe, screen, and accessories (cap, centralizers) shall be cleaned and decontaminated after cutting and threading at the factory. Cleaning shall be done using a mild detergent, followed by an isopropyl or methanol alcohol rinse, and then rinsed with clean water or by using an approved equivalent cleaning procedure. The materials shall be air dried and hermetically sealed in plastic to minimize the potential for contamination before installation in the borehole. Chiorinated solvents shall not be used for cleaning pipe or screen. The personne] 
handling the materials will have clean hands or use new rubber gloves and are required to wear clean coveralls.

6. Proper installation of each well is critical to the integrity of the data collected from it. Design specifications will be followed as closely as possible. Any deviations from prescribed design must meet the approval of the site geologist.

\section{IASK 4. HYDROLOG IC TESTING}

Aquifer testing will be performed on chosen wells if no ground-water contamination above acceptable limits is detected on reaching the water table. These tests may include bailer, slug, step-drawdown, 8-hour pumping, and 8-hour recovery. Observation wells will be used where possible. A pretest analysis (generally a step-drawdown test) based on an estimated range of transmissivity will be conducted. The purpose of this step-drawdown test is to determine the type of test and the size of pump most applicable to the given field situation. The aquifer test will not be performed until water Tevels have recovered fully from the step-drawdown test.

Proper disposal of discharge water from pumping tests is often a problem at hazardous waste sites. An Effluent Monitoring Plan will be in place before aquifer testing begins. This will identify the acceptable limits of contamination for disposal of pumped water to the ground surface. A groundwater sample will be collected and analyzed before aquifer testing. If no contamination is detected above acceptable 1 imits, the test will proceed, with discharge to the ground surface at an acceptable distance from any waste disposal facilities. If ground-water contamination is detected, aquifer testing will not occur until a decision is made on whether treatment and disposal of pumped water is necessary.

\section{REFERENCES}

29 CFR 1910. 120. 1986. 0ccupation Safety and Health Administration, "Hazardous Waste Operations and Emergency Response." U.S. Code of Federal Requlations, Office of the Federal Register, Washington, D.C.

Ahrens, T. P. 1970. "Basic Considerations of Well Design: Part III." Water Well Journal 24(3):47-51. 
Folk, R. L. 1968. Petrology of Sedimentary Rocks. University of Texas, Austin, Texas.

Raber, E., J. Garrison, and V. Oversby. 1983. "The Sorption of Selected Radionuclides on Various Metal and Polymeric Materials." Radioactive Waste Management and the Nuclear Fue 1 Crcle 4(1):41-52.

Sneed, E. D. and R. L. Folk. 1958. "Pebbles in the Lower Colorado River, Texas, A Study in Particle Morphogenesis." Journal of Geology 66:139-183. 
APPENDIX D

SAMPLING AND ANALYSIS PLAN 
APPENDIX D

\section{SAMPLING AND ANALYSIS PLAN}

This plan introduces the procedures that will be used for sample collection (including well evacuation and sample withdrawal methods), field measurements, sample preservation and shipment, chemical analysis, chain of custody, and quality control.

All sampling activities are currently performed under contract by Pacific Northwest Laboratory (PNL). United States Testing Company (UST) currently conducts sample analyses for most constituents. The procedures in this appendix have been extracted primarily from PNL's Environmental Monitoring Procedures manual (PNL-MA-580). The procedures for laboratory analyses done by UST are documented in UST-RD-PM-9-80, VoT. 1 and 2, for radioactive constituents and UST-RD-PM-9-80, Vol. 3 for hazardous constituents (UST 1986). If any of these procedures are updated, the new procedures will be followed for this program, superseding any previous procedures. 


\subsection{SAMPLE COLLECTION PROCEOURES}

\subsection{INTRODUCTION}

These procedures are intended for use in collecting ground-water samples that will be analyzed for hazardous chemicals.

\subsection{EQUIPMENT}

The following equipment may be needed in the field during sampling:

- truck-mounted air compressor and generator

- bladder-pump controller box

- bladder-pump hoses (set of two)

- extra discharge line for bladder pump

- extra discharge line for submersible pump

- Teflon bailer

- $\mathrm{pH}$ and conductivity meter

- digital thermometer

- steet measuring tape

- blue chalk

- electrical tape

- engineer's measurement tape

- a copy of Hanford Wells (PNL-5397) (McGhan, MitcheT1, and Argo 1985)

- stopwatch or watch with second hand

- bucket or jug (for measuring flow rate)

- distilled water

- ziplock bags

- ice chests with ice

- plastic gioves

- aprons

- towels

- indelible marker

- extra sample labels

- sample seals

- a copy of all relevant procedures

- sample containers with caps and liners (including extras) 
- field record forms

- chain-of-custody forms

- sample analysis request forms.

\subsection{SAMPLING PRECAUTIONS}

Do not smoke, eat, or handle any objects not necessary for sampling while performing sampling procedures.

Do not sample downwind of any potential sources of volatile organics such as car exhausts or open fuel tanks. These could contaminate the sample. If any such sources are unavoidable, make a note of them on the field record forms.

Leave caps on the sample containers until just before filling.

Avoid handling the Teflon bottle cap liners. Do not use any liner that falls out of the cap and onto the ground.

Wear gloves when taking samples and when handling containers, especially those with added preservative.

\subsection{SAMPLE COLLECTION USING SUBMERSIBLE PUMP}

Take water level measurements according to the water level measurement procedure (Section 2.1).

Check to see that the hose bibb for the submersible pump is open. CAUTION: Be sure the power switch on the $230-V$ outlets is turned off!

Plug the power cord into one of the 230- $V$ outlets on the generator on the truck and into the outlet at the well head.

Start the electric generator.

Turn the power switch on to begin pumping process. Be sure not to handle energized power cords. If the pump does not work properly, as indicated by a lack of air flow out the discharge hose or by failure of the generator to "lug" down, turn the switch off immediately. After waiting a few seconds, turn the switch on and off several times rapidly, finally pausing in the ON position to determine if the pump has started to function properly.

\section{D.3}


After the water begins to flow from the outlet, pump the well for 15 min (or longer, if the $\mathrm{pH}$, temperature, and specific conductivity have not stabilized).

NOTE: Some wells pump down after a period of time. If the well pumps dry while purging, it does not generally mean that a sample cannot be collected. A sample can still be obtained by following these steps:

1. Turn off the submersible pump when the well pumps dry.

2. Wait for the well to recharge. This should be about $15 \mathrm{~min}$, but may take as long as $30 \mathrm{~min}$.

3. Measure the depth to water using the electrical tape. Make sure that the water level is above the pump intake.

4. Turn the submersible pump back on. Collect the samples that are designated for collection with the submersible pump.

Measure the $\mathrm{pH}$, temperature, and specific conductivity of the discharged water at least three times during purging, according to the standard procedures for measuring $\mathrm{pH}$ and conductivity (explained in Section 2.0 of this appendix). The pH will be considered stable when two consecutive measurements agree within $0.2 \mathrm{pH}$ units. Temperature will be considered stable when two consecutive measurements agree within $0.2^{\circ} \mathrm{C}$. Conductivity will be considered stable when two consecutive measurements agree within $10 \mu$ mhos. If $\mathrm{pH}$, temperature, and conductivity do not stabilize within the calculated purging time, contact the technical supervisor before collecting samples.

Enter time, date, and your initials on all sample labels.

Record information on field record form as it becomes available. The information that must be recorded on the field record forms is described in Section 2.0, "Chain-of-Custody Procedures."

Check the labels on the sample containers to determine which ones can be filled using the submersible pump. (A blue line on the right side of the sample label indicates that the submersible pump should not be used to fill that particular container.) 
Fill the appropriate sample containers as described in Section 1.8, "General Sample Collection Procedure."

Attach a sample seal to each container and place it in a cooler or ice chest.

\subsection{SAMPLE COLLECTION USING BLADDER PUMP}

If the well has a dedicated bTadder pump, turn on the air compressor and use the procedure described below. If the well does not have a bladder pump, use the procedures given for the Teflon bailer to collect the remaining samples.

Attach the compressor to the bladder-pump pressure inlet on the face of the controller panel, using the fenale portion of the coupling supplied.

Connect either end of the controller's red air hose to the pump supply on the right side of the control panel. Connect the other end of the controller air hose to the quick-connect nipple located in the well cap assembly.

Attach the appropriately labeled extension line to the bladder-pump discharge line.

Five of the 15 pumping cycles are required to purge the air from the bladder pump and tubing. Full water flow from the sample supply tube should then begin. After water flows from the out let tube, run the bladder pump for at least $5 \mathrm{~min}$ before taking samples.

To reduce the water flow rate during sample collection, turn the throttle control on the left side of the control panel in the counterclockwise direction. To increase the flow rate, turn the throttle control clockwise.

\subsection{SAMPLE COLLECTION USING THE PISTON PUMP (HYDROSTAR)}

Upon arrival at the well head, imnediately determine depth to water using the appropriate tapes, and record the detemined values on the field record form.

Wear gloves when taking samples and when handling containers, especially those with added preservative. 


\section{Attaching the Pneumatic Cylinder Assembly}

1. Insert the support for the pneumatic cylinder into the column support on the well head assembly. (a)

2. Pull the cylinder rod down until it is fully extended and has stopped.

3. Align the eyelet on the top portion of the turnbolt with the clevis pin hole on the lower portion of the cylinder rod.

4. Align the hole on the cylinder support with the column support on the well head so that the turnbolt eyelet and clevis pin hole on the cylinder rod are aligned when the piston is fully extended.

5. Insert the clevis pin through one of the intersecting pairs of holes on the column support and clip a hitch pin into the holes in the small end of the clevis pin.

6. Check the alignment on the turnbolt eyelet with the hole on the cylinder rod. The alignment must be nearly perfect, neither too high nor too low.

7. Adjust by rotating the turnboit clockwise or counterclockwise.

\section{Operating the Pneumatic Cylinder}

1. Attach either the purging hose (large diameter) or the Teflon sampling hose to the outlet on the discharge tee of the sampling pump.

2. Attach the quick-connect on the supply hose to the unattached end of the control valve on the pneumatic cylinder. The input air pressure should not exceed 120 psi.

(a) When inserting the cylinder support into the column support on the pump assembly, at least two holes on the cylinder support must overlap with two holes on the column support. If less than two holes overlap use the extension supplies with the Hydrostar pneumatic cylinder. Align the pumping system in the same manner as described above. 
3. Turn air supply on to the control valve.

4. Turn on the control valve on the pneumatic cylinder. The piston will begin to operate.

5. Adjust stroke rate to no more than 60 per minute. (a) The stroke speed of the pneumatic cylinder can be adjusted with the control valve located on the top of the pneumatic cylinder. A stroke is defined as one downward and one upward extension.

\section{Sampling with Preumatic Piston Assembly}

1. Slow down the pumping rate until the piston operates smoothly. This rate will be less than 10 strokes per minute.

2. Attach the Teflon sampling hose and purge at this rate for a minimum of 2 min.

3. Proceed with sampling all unfiltered samples according to PNL-MA-580.

4. Attach the filter assembly and purge the filter according to directions listed in PNL-MA-580. If too much pressure is exerted across the filter the membrane will rupture, usually resulting in a popping noise. If this happens, replace the filter and restart the filtering procedure.

5. Dismantle the pneumatic pumping assembly as described below.

\section{Removing the Pneumatic Pumping Assembly}

1. Disconnect the air supply at the pneumatic cylinder.

2. Disassemble pneumatic cylinder in reverse order of steps 1 through 7 in the section "Attaching Pneumatic Cylinder Assembly."

3. Replace well cap over top of weil head.

(a) If the pneumatic cylinder assembly is not operating correctly, and the problems are not due to the well or the pump in the well, the well may be hand pumped as described in "Manual Operation." 


\section{Manual Operations}

1. Insert the handle support into the column support on the pump head assembly so that at least two holes on the handle support overlap two holes on the column support.

2. Slide the clevis pin through one of the intersecting pairs of holes on the column support.

3. Clip the hitch pin into the hole in the small end of the clevis pin.

4. Remove the turnbolt on the top of the rod at the well head.

5. Attach the turnbolt on the end of the wire rope attached to the handle assembly onto the threaded rod at the top of the well head.

6. Lift the handle so that the flat edge of the cam nearest the shackle is approximately parallel with the ground.

7. Pull all the slack out of the wire rope.

8. Using either an adjustable or 9/16-in. open-end wrench, tighten both nuts on the shackle until the sheath on the wire rope is compressed. Remembering to keep all slack out of the wire rope.

Manual Well Sampling

1. Attach either the purging hose (large diameter) or the Teflon sampling hose (smali diameter) to the outlet on the discharge tee of the sampling pump.

2. Begin pumping the operating handle with smooth, even strokes. For best performance, use 20 to 45 strokes per minute for purging the well. Use less than 10 strokes per minute during sampling. When the filter assembly is attached, special attention is required to prevent rapid build up of pressure across the filter. If too much pressure is exerted across the filter the membrane will rupture, usually resulting in a popping noise. If this happens, replace the filter and begin sampling for the filtered sample according to the written procedure. 
3. When sampling is completed follow the direction below to disassemble the handle assembly from the well head.

Removing the Handle Assembly

Disassemble the handle assembly in reverse order of steps 1 through 8 in the section "Manual Operations."

\subsection{SAMPLE COLLECTION USING TEFLON BAILER}

Unclasp the metal bailer from the winch line and replace it with the Tefion bailer.

Disengage the winch clutch and slowly lower the bailer into the water. Engage the winch clutch when the bailer strikes the water surface.

Allow about $30 \mathrm{sec}$ for the sample tube to fill.

Turn the electric winch and slowly raise the Teflon bailer to the surface. Lower and rinse the bailer twice before collecting a sample.

Unscrew the cap of the sample container, being careful not to touch the lip of the bottle or the inside of the Teflon liner. Avoid touching the mouth of the Teflon bailer.

Unclasp the Teflon bailer.

Pour the water from the bailer into the sample container slowly to prevent trapping any air bubbles. Avoid splashing or agitating the water while the sample container is being filled.

\subsubsection{Teflon Bailer Cleaning Procedure}

Wash the inside and the outside of the bailer with a mild mixture of dish soap and water.

Rinse the bailer twice with tap water.

Store the bailer in a sealable plastic bag between uses. 


\subsection{GENERAL SAMPLE COLLECTION PROCEDURE}

Unscrew the cap from the sample container, being careful not to touch the lip of the bottle or the inside of the Teflon liner. Also avoid touching the mouth of the discharge line.

Fill the sample bottle slowly by placing the outlet tube against the inner side of the sample bottle to prevent trapping any air bubbles. Avoid splashing or agitating the water while the bottle is being filled.

NOTE: For those bottles requiring no headspace, the bottle should be filled completely so that a meniscus forms. Cap the bottle immediately, turn it upside down, tap it a few times and check for air bubbles in the sample. If a bubble exists, discard the sample and repeat the sampling procedures until an air-free sample is obtained. There is an exception to this; if the bottle to be filled contains a preservative, only one attempt will be made to obtain an air-free sample.

As each container is filled, attach a sample seal to it and place it in a cooler or ice chest.

Survey the sample container with a $G M$ instrument. If the count is greater than $200 \mathrm{cpm}$, record it on the field record form and use Radiation Work Procedure 318-EE-1. Contact the EM Supervisor for instructions concerning where the sample is to be taken.

Turn off the air compressor.

Turn the power switch off and then turn the generator off. Unplug the power cord.

Complete the chain-of-custody and sample analysis request forms.

Deliver the sample to the appropriate laboratory for analysis as soon as possible, following chain-of-custody procedures. If it cannot be delivered to the lab the same day, store the sample in a refrigerator located inside a locked building or within a secured area. The refrigerator must maintain a constant temperature of $4^{\circ} \mathrm{C}\left(39^{\circ} \mathrm{F}\right)$. Leave the cooler to be used when the samples are delivered. 


\subsection{FIELD MEASUREMENTS}

\subsubsection{Water-Level Measurement Procedure}

Introduction

Water level measurements are taken each time a well is sampled, before it is purged. These measurements are taken as depth to water from the top of the well casing. They must be subtracted from the surveyed elevation of the casing given in Hanford Wells (McGhan, Mitchell, and Argo 1985, PNL-5397) to obtain the elevation of the water table. The water table elevations obtained for all wells in the sampling network during a particular sampling episode can be used to produce a contour map showing the ground-water surface at the time that the measurements were made. These contour maps can be used to help characterize the ground-water flow system and to ensure that the sampling network is adequate.

Graduated steel measuring tapes are more accurate than electrical tapes and so should be used for official measurements. However, an electrical tape can be used to determine the approximate depth to water.

\section{Equipment}

The following equipment will be needed:

- steel measuring tape with attached weight

- blue carpenter's chalk

- a copy of Hanford Wells (PNL-5397)

- electrical tape

- engineer's measuring tape

- field record forms.

\section{Graduated Steel Tape Method}

Chalk the $1-\mathrm{ft}$ section of steel tape below the zero reading point.

Find the elevation of the measuring point and the estimated water leve? in Hanford Wells, or use an electric tape to find the approximate depth to water.

Lower the steel tape from the well's measuring point (marked with paint on the top of the casing) to the estimated water level. Note the amount of 
tape that is in the well by reading the tape at the measuring point. This value is referred to as the "hold point."

Remove the steel tape and check the wetted portion below the zero reading point.

NOTE: If the chalked portion is not wet, repeat the procedure, but allow more of the tape to go down the well (i.e., use a greater hold point).

Add the unwetted length of the chalked portion of the tape to the hold point value to obtain the depth-to-water measurement.

If the chalked portion is not wet, repeat until the water level is marked on the chalked portion of the tape.

Repeat the procedure until two steel tape measurements agree within \pm 0.05 $\mathrm{ft}$.

Record the depth-to-water measurements, time of measurements, measuring device, and the name of the person taking the measurements on the field record form.

\section{Electric Tape Method}

Lower the electric tape from the measuring point into the borehole until the buzzer and the light indicate contact with the water.

Mark the electric tape at the measuring point and identify the nearest graduation on the electric tape.

If the water level is deeper than the nearest graduation marked on the tape, add the difference to the depth identified to obtain the true depth to water.

If the water level is shallower than the nearest graduation marked on the tape, subtract the difference from the depth identified to obtain the true depth to water.

Record the depth-to-water measurements, time of measurements, measuring device, and the name of the person taking the measurements on the field record form. 
NOTE: This measurement should be used only as an approximate depth to water, because the electric tape is less reliable than the steel tape.

\subsubsection{Temperature Measurement Procedure}

Introduction

Temperature measurements are taken during and after purging of the wel1, just before sample collection. Measurements taken during purging are used to help ensure that the well bore has been sufficiently evacuated, as indicated by stabilization of the temperature. (The $\mathrm{pH}$ and conductivity are measured at the same time for the same reason.) The temperature is considered stable when two consecutive measurements agree within $0.2^{\circ} \mathrm{C}$. The final temperature measurement is taken just before sampling and is recorded as an analytical value for the sample. The digital thermometers are regularly checked against a standard thermometer for accuracy.

Equipment

The following equipment will be needed:

- digital thermometer

- field record forms.

\section{Temperature Measurement Procedure}

Turn on the digital thermometer. Make sure that the switch is positioned so that the measurements will be in degrees centigrade.

Place the probe into the stream of water being discharged from the pump.

The temperature is indicated by a flashing display, which will normally fluctuate for a few seconds. Wait until fluctuation ceases (i.e., until the same temperature is indicated on three consecutive flashes), and then record the temperature on the field record form.

\subsubsection{Conductivity Calibration and Measurement Procedures.} Introduction

Conductivity measurements are taken during and after purging of the well, just before sample collection. Measurements taken during purging are used to help ensure that the well bore has been sufficiently evacuated, as indicated 
by stabilization of the conductivity. The $\mathrm{pH}$ and temperature are measured at the same time for the same reason.) Conductivity is considered stable when two consecutive measurements agree within $10 \mu$ mhos. The final conductivity measurement is taken just before sampling and is recorded as an analytical value for the sample. The conductivity meter should be calibrated once a day, before it is taken to the field to begin sampling.

Equipment

The following equipment will be needed:

- conductivity meter

- distilled or deionized water

- small screwdriver

- standard solution

- field record forms.

\section{Conductivity Calibration Procedure}

\section{Internal Standard}

Empty the sample cup on the meter. Rinse it out with distilled or deionized water. Dry the cup thoroughily.

Turn the range switch to TEST.

Press the OPERATE button.

Use the small screwdriver to adjust the CALIBRATE until the meter or display reads 8 .

NOTE: This is to be done as a rough calibration or battery check.

Standard Solution

Empty the sample cup. Rinse it out with distilled or deionized water.

Fill the cup with standard solution.

Turn the MODE switch to conductivity.

Turn the RANGE selector switch to the correct range for the standard solution.

Press the OPERATE button. 
Use the small screwdriver to adjust the CALIBRATE until the meter or display reads the solution value.

NOTE: Do not return the conductivity standard solution to the container. Always discard it.

\section{Conductivity Measurement Procedure}

Check that the conductivity meter is properly calibrated by using the internal standard.

Remove the cap from the sample cup.

Rinse the cup with the water to be tested and dump it several times. Then fill the cup with the sample.

Turn the conductivity RANGE switch to the correct range.

\begin{tabular}{ll}
\multicolumn{2}{r}{ Range in $\mu_{\text {mhhos }}$} \\
\hline X1. & $0=10$ \\
X10. & $0=100$ \\
X100. & $0=1,000$ \\
X1,000. & $0=10,000$
\end{tabular}

Turn the MODE switch to CONDUCTIVITY.

Press the OPERATE button on the side of the meter.

Read the conductivity on the digital display to the nearest umho and record on field record form. Multiply the meter reading times the scale factor to obtain the correct placement of the decimal point.

After taking the reading, dump the sample and refill the cup with distilled water.

Replace the cap.

\subsection{4 $\mathrm{pH}$ Calibration and Measurement Procedure}

Introduction

Measurements of $\mathrm{pH}$ are taken during and after purging of the well, just before sample collection. Measurements taken during purging are used to help ensure that the well bore has been sufficiently evacuated, as indicated by 
stabilization of the $\mathrm{pH}$. (Conductivity and temperature are measured at the same time for the same reason.) The $\mathrm{pH}$ is considered stable when two consecutive measurements agree within $0.2 \mathrm{pH}$ units. The final $\mathrm{pH}$ measurement is taken just before sampling and is recorded as an analytical value for the sample. The $\mathrm{pH}$ instrument should be calibrated once a day, before it is taken to the field for sampling.

Equipment

The following equipment will be needed:

- pH meter

- distilled or deionized water

- small screwdriver

- buffer solutions

- field record forms.

pH Calibration Procedure

Wash the meter's sample cup with distilled water.

Fill the cup with $4.0 \mathrm{pH}$ buffer solution.

Turn the MODE switch to $\mathrm{pH}$.

Press the OPERATE button. Use the small screwdriver to adjust the ZERO to make the display read $4.00 \mathrm{pH}$ on the upper meter scale or on the digital display.

Discard the buffer solution. Wash the cup twice with distilled or deionized water.

Fill the cup with 10.00 buffer solution.

Adjust the SLOPE to make the display read $10.00 \mathrm{pH}$.

Rinse the cup again and refill it with $4.0 \mathrm{pH}$ buffer solution. Recheck the $4.0 \mathrm{pH}$ value and adjust the ZERO if necessary. Singe Buffer Calibration

After the SLOPE is calibrated the first time each day, it may be left alone for subsequent calibration. Recheck the slope as desired. 
Calibrate with a buffer solution that is close to the range of interest. If the process $\mathrm{pH}$ is from 6.0 to 9.0 , use a 7.0 buffer solution for singlepoint calibration.

With the buffer solution in the cup, recalibrate only the STD to make the display read the desired value.

NOTE: Do not return buffer solutions to their containers. Always discard them.

$\mathrm{pH}$ Measurement Procedure

Ensure that the $\mathrm{pH}$ instrument is properly calibrated.

Remove the cap from the sample cup.

Rinse the cup with the water to be tested several times. Then fill the cup with the sample.

Turn the MODE selector switch to $\mathrm{pH}$.

Press the OPERATE button on the side of the meter.

Read the $\mathrm{pH}$ on the upper meter scale or on the digital display to the nearest tenth of a unit. Record the value on the field record form.

Dump the sample and refill the cup with distilled water.

Replace the cap. 


\subsection{CHAIN-OF-CUSTODY PROCEDURES}

To ensure the integrity of the samples from the time of collection through data reporting, the history of the custody of each sample will be documented according to these procedures. A sample is considered to be under a person's custody if it is in any of the following stages: 1) in his physical possession; 2) in his view after he has taken possession; 3) secured by him so that no one can tamper with the sample; or 4) secured by him in an area that is restricted to authorized personnel. Anyone having custody of samples must comply with the procedures described here.

\subsection{DELIVERY PROCEDURES}

SampTe Labeis

Fill out and affix gumned paper Tabels to the sample containers before or at the time of sample collection. The well number noted on the label identifies the well location where the sample was collected. An example sample label is shown on Figure D.1.

Sample Seals

Attach gummed paper seals to the samples immediately upon sample collection, before the samples leave your custody. Attach the seal in such a way that the sample cannot be opened without breaking the seal.

Field Record Form

Record (in black ink) all pertinent information about each sample collected on a field record form and insert into a logbook. The logbook is a bound book with consecutively numbered pages. An example field record form is shown in Figure D.2.

Chain-of-Custody Form

A chain-of-custody form will accompany all samples from the time they are collected until they are disposed of after analysis and reporting. A single form will be used for as many samples as possible. The form to be used is shown in Figure D.3. Each person who handles the sample and signs 
(sample number) - company code

(well number)

(bottle preparation)

SAMPLE SIZE:

$L A B$ :

DATE/TIME :

COLLECTOR:

\section{FIGURE D.1. Sample Label}

the form will return a copy of the form to the company contact whose name appears on the top line.

\section{Sample Analysis Request Form}

United States Testing (UST) requires that a sample analys is request form accompany all samples delivered to the lab. The field portion of the form will be completed by the sample coilector; the laboratory portion will be completed by laboratory personnel. An example sample analys is request form is shown in Figure $\mathbf{D . 4}$.

Samples are normally delivered directly to the laboratory on the day of collection. If they cannot be delivered on the day of collection, they must be stored them in a refrigerator in a locked building. (No shipping of the samples is necessary, due to the lab's proximity to the site.) All samples will be accompanied by a chain-of-custody form and a sample analysis request form. Deliver samples only to authorized laboratory personnel.

\subsection{LABORATORY ACCEPTANCE PROCEDURES}

The chain of custody does not end at the laboratory door, and therefore the laboratory must ensure the continuity of its record by following these procedures. 


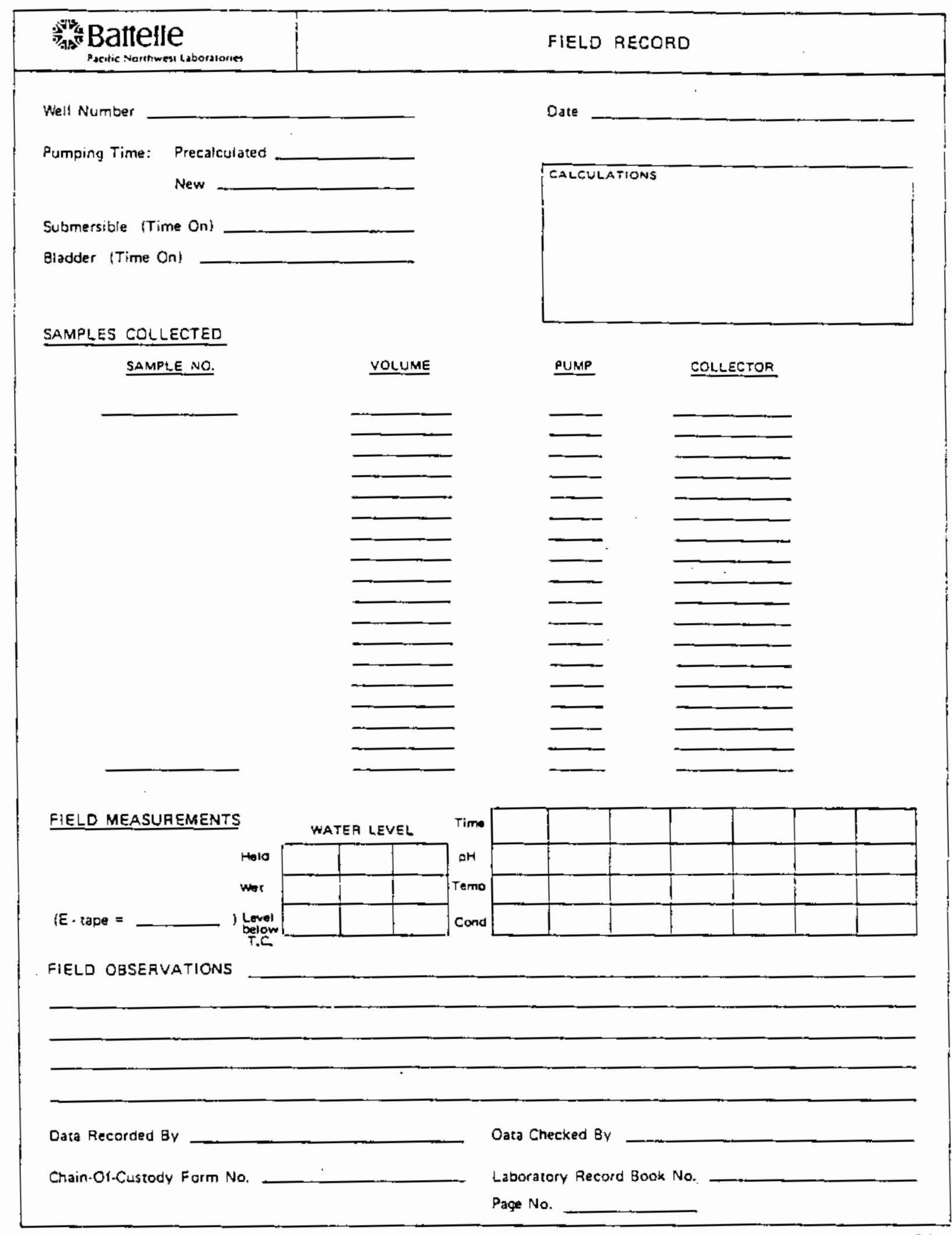

FIGURE D.2. Field Record Form 


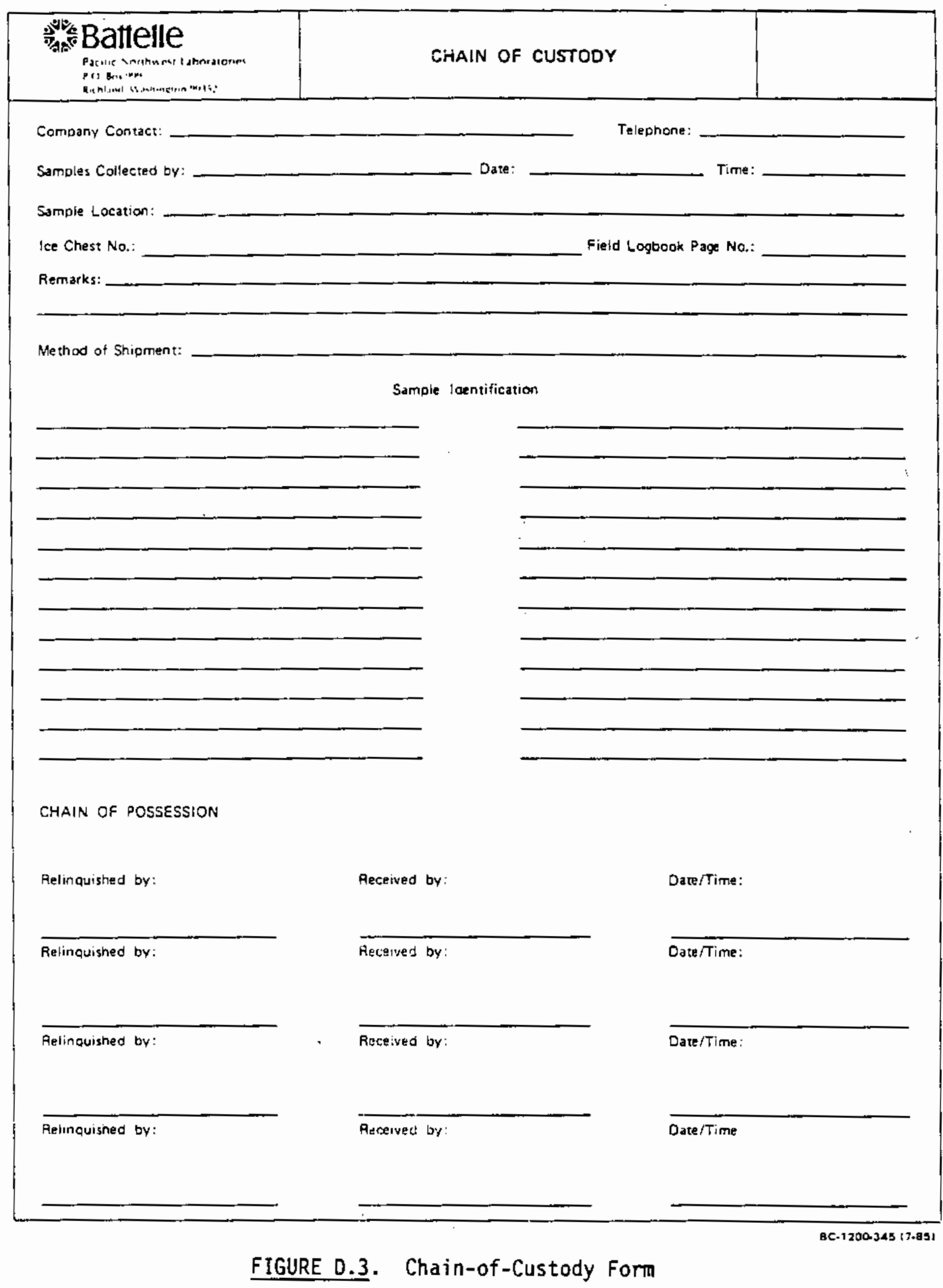


Pacitic notehuese badoracory

$P O$ JOX 999

Richland WA 99352

coilector

Date /Trme Samplad

company coneacs

CUAIN OF CUSTOOY NO.

SAMPLE ID

UST SAMPLE ID

GOMMENT
United ststes zeseing Company, ins.

2800 George Hasiningcon way

Richland Wa 99352

Recelveo by

Tlebe

Dace Iime

\begin{tabular}{|c|c|c|c|}
\hline & CODE & CONSTITUENT & \\
\hline$i$ & 723 & ICP METALS 5010 & \\
\hline 2 & $2 \geq 5$ & ECP METALS 60:0 ENHANCED & \\
\hline 3 & $A 20$ & ARSENII & \\
\hline \pm & 221 & MERCURY & 1 \\
\hline$j$ & $A 2 \overline{2}$ & SELENIUM & \\
\hline$\dot{0}$ & $\Delta 23$ & PHALLIUM & \\
\hline 7 & A24 & THIOGREA 8330 & \\
\hline 3 & 727 & METHOD 8330 ENHANCED & \\
\hline 9 & $A \bar{L}$ & EEAD DY GEAA & 1 \\
\hline 20 & 399 & ?C3 & \\
\hline $1 i$ & 728 & PESIICIDES 8090 & 1 \\
\hline 12 & 729 & PESIICIDES 8080 ENHANCED & \\
\hline 13 & $730^{\circ}$ & YOA MEIHOO 3240 & \\
\hline it & 731 & VOA METHOD 8240 ENHANCED & \\
\hline 15 & 732 & $A / B / N 8270$ & \\
\hline$i 5$ & 733 & $A / 3 / N$ 3270 ENHANCED & \\
\hline 27 & 734 & PESTICIDES METHOD 9140 & i \\
\hline I8 & $c 68$ & $70 x$ & \\
\hline 19 & 659 & $\mathrm{IOC}$ & \\
\hline 20 & 670 & CYANIDE & \\
\hline $2 !$ & 735 & NIFRATE, SUCPHAIS, . . (IE) & \\
\hline 22 & 677 & PERCHLORATE & \\
\hline 23 & 678 & SULEIDE & 7 \\
\hline 24 & 680 & $\triangle M M O N I U M$ ION & \\
\hline 25 & $\mathrm{COI}$ & EIHYLENE GLYCOL & \\
\hline 26 & 109 & COLIFORA BACEERIA & \\
\hline 27 & 181 & RAOIUM & \\
\hline 28 & 132 & ALPHA & \\
\hline 29 & 111 & BETA & \\
\hline 30 & 636 & DIOXIN & \\
\hline 31 & 687 & CITRUS RED $=2$ & \\
\hline 32 & 191 & CONOUCIIVIFY & \\
\hline 33 & 199 & 매 & \\
\hline 14 & 736 & OIRECT AQUEOUS INJECIION & \\
\hline 35 & 738 & HERBICIDE 2,4-0, 2,4,3-TP SIEVEK & \\
\hline 36 & 737 & HEREICIDE B150 ENHANCED & \\
\hline
\end{tabular}




\section{Receiving Department}

Remove the sample cooler from the delivery vehicle and bring it into the receiving area.

Check the sample cooler for any obvious damage.

Sign the chain-of-custody and sample analys is request forms.

If you transfer custody of the cooler to one or more intermediates before it is delivered to the Sample Custodian, the chain-of-custody form must reflect every change of custody.

\section{Sample Custodian}

When the sample cooler is delivered to you (or your designated alternate), sign the chain-of-custody form. Then return one copy to the sender and retain the remaining copies. The sample cooler is now your responsibility (or that of your designated alternate). You must now log in the samples.

Examine the sample coolers. On the sample log-in form (Figure D.5), record:

- presence/absence of custody seal(s) on the samples

- condition of custody seal(s).

Open the sample coolers, examine the sample documents, and record on the sample $\log$-in form whether chain-of-custody form(s) are present.

Remove sample containers and record on sample log-in form:

- condition of samples (intact, broken, leaking, etc.)

- presence/absence of sample labeis and sample seals

- any discrepancy with chain-of-custody form(s).

If discrepancies are found, contact the sender for clarification.

After all samples have been properly logged in, send a copy of the sample log-in form to the company contact named on the chain-of-custody form. 
OATE:

TIME:

COOLER IO

CLIENT SAMPLE ID:

UST-RO ID

NUMGEP OF BOTTLES IN COOLER

IS CHAIN OF CUSTOOY FORM PRESENT? :

CHAIN OF CUSTOOY NUMBER

IS SAMPLE AIALYYSIS REQUEST FORM PRESENT? :

* is the custody seal on the cooler intact? :

* are the custooy seals on the bottles intact? :

* do the sample labels agree hith the chain of custooy sheet? :

* do the sample labels agree hith the sample amalysis REQUEST SHEET? :

* if ansher is 'no', please explain belon in detail.

SAMPLES LOGÜEO IN BY:

REVIEHED BY SAMPLE CUSTOOIAN:

Govind Rao

FIGURE 0.5 . Sample Log-In Form 
Use an internal numbering system for identification of all samples. Assign internal numbers to the samples and record the numbers on the sample $\log$-in form alongside the corresponding sample number assigned by the collector. Place the properly labeled sample containers in the secure storage area. 


\subsection{ANALYTICAL METHODS}

TABLE D.1. Preservation Techniques, Ana7ytical Methods Used, and the Current Detection Levels for Listed Constituents

Collection and

Constituent
Detection Limit. ppb(d)

\section{ICP METALS}

Barium
Cadmium
Chromium
Silver
Sodium
Nickel
Copper
Vanadium
Aluminum
Manganese
Potassium
Iron
Calcium
Zinc
Arsenic
Mercury
Selenium
Lead

$\underline{\text { IC }}$

$\left.\begin{array}{l}\text { Nitrate } \\ \text { Sulfate } \\ \text { Fluoride } \\ \text { Chloride } \\ \text { Phosphate } \\ \text { Bromide } \\ \text { Nitrite }\end{array}\right\}$

Total Organic Halogen, low detection level

Total Organic Carbon

Tota? Carbon

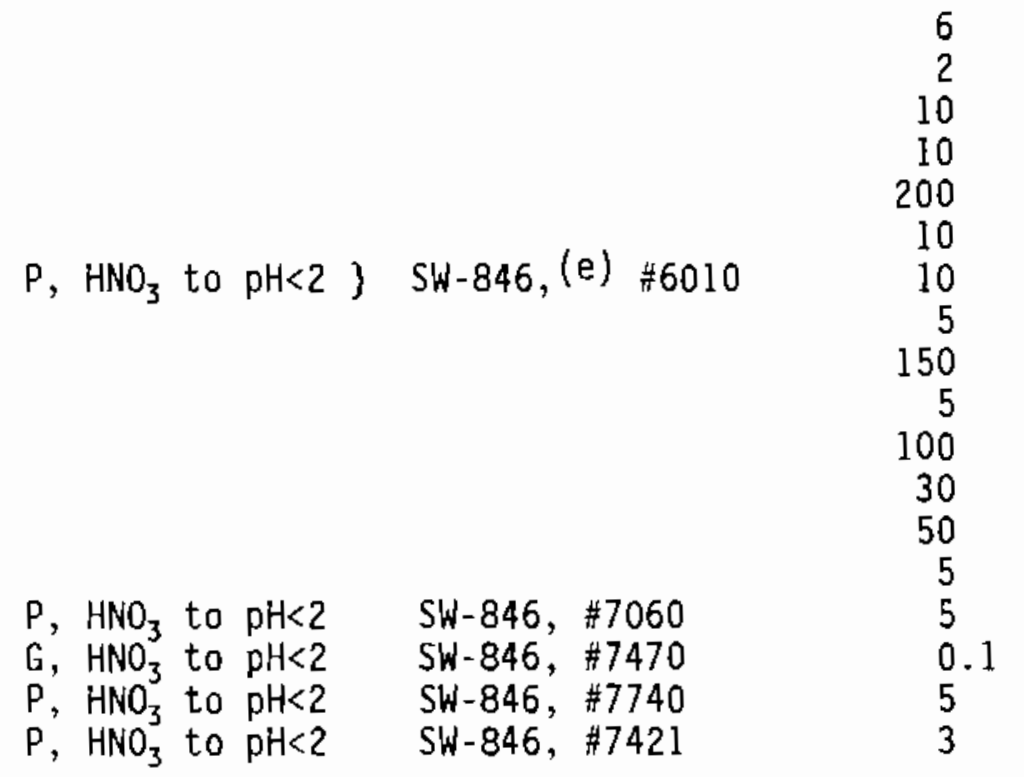

500

500

500

500

1000

1000

1000

$\mathrm{G}, \mathrm{H}_{2} \mathrm{SO}_{4}$ to $\mathrm{pH}<2 \quad \mathrm{SW}-846, \# 9020 \quad 20$

No headspace

$\mathrm{G}, \mathrm{H}_{3} \mathrm{PO}_{4}$ to $\mathrm{pH}<2 \quad$ EPA Method $\$ 9060 \quad 1000$

$G$, None 
IABLE D.1. (contd)

\begin{tabular}{|c|c|c|c|}
\hline ins & $\begin{array}{c}\text { Collection and } \\
\text { Preservation }(a, b)\end{array}$ & Methods (c) & $\begin{array}{r}\text { Detection } \\
\text { Limit, ppb }\end{array}$ \\
\hline $\begin{array}{l}\text { Ammonium ion } \\
\text { Phenol } \\
\text { Cyanide }\end{array}$ & $\begin{array}{l}\mathrm{G}, \mathrm{H}_{2} \mathrm{SO}_{4} \text { to } \mathrm{pH}<2 \\
\mathrm{G}, \mathrm{None} \\
\mathrm{P} \text {, NaOH to } \mathrm{pH}<2\end{array}$ & $\begin{array}{l}\text { SW-846, } \# 8040 \\
\text { SW-846, } \# 9010\end{array}$ & $\begin{array}{l}50 \\
10 \\
10\end{array}$ \\
\hline
\end{tabular}

PESTICIDES

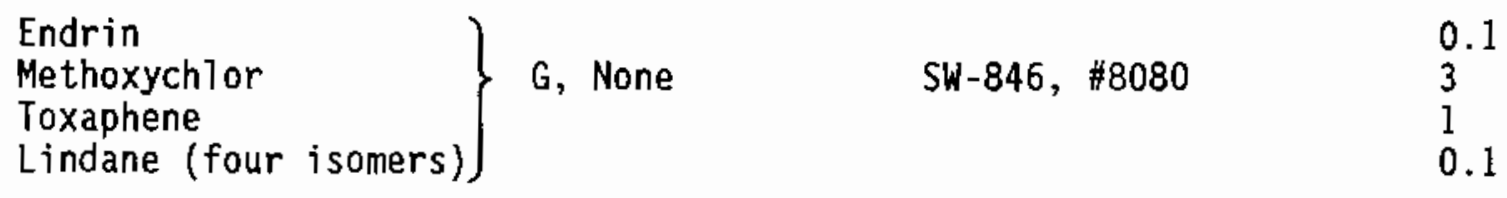

\section{HERBICIDES}

2, 4-D

2,4,5-TP silvex

SW-846, \#8150

\section{VOLATILE ORGANICS (VOA)}

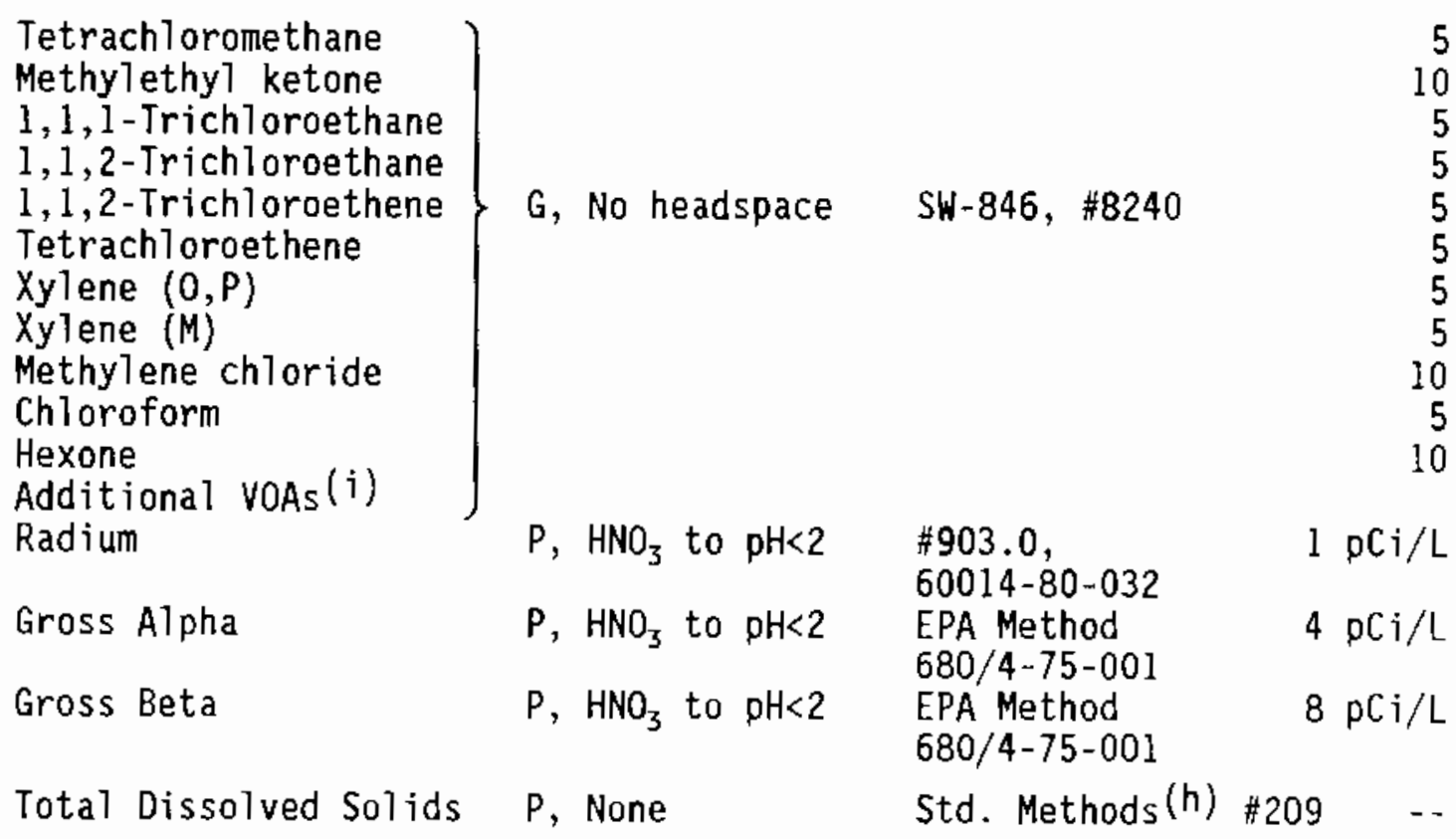


TABLE D.1. (contd)

\begin{tabular}{|c|c|c|c|}
\hline Constituent & $\begin{array}{l}\text { Collection and } \\
\text { Preservation }(a, b) \\
\end{array}$ & Methods (c) & $\begin{array}{r}\text { Detection } \\
\text { Limit, ppb(d) }\end{array}$ \\
\hline Coliform bacteria & $P$, None & $\begin{array}{l}\text { Std. Methods } \\
\# 908(\mathrm{pH}, \mathrm{lab})\end{array}$ & $\begin{array}{l}2.2 \mathrm{MPN} \\
\mathrm{P}, \text { None }\end{array}$ \\
\hline Methods \#423 & -- & & \\
\hline Temperature & Field measurement & $\begin{array}{l}\text { PNL MA-580, } \\
\text { Section } 3.4\end{array}$ & \\
\hline Specific conductance & Field measurement & $\begin{array}{l}\text { PNL MA-580, } \\
\text { Section } 3.5\end{array}$ & \\
\hline $\mathrm{pH}$ & Field measurement & $\begin{array}{l}\text { PNL MA-580, } \\
\text { Section } 3.6\end{array}$ & \\
\hline
\end{tabular}

(a) P, plastic; G, glass.

(b) All samples will be cooled to $4^{\circ} \mathrm{C}$ upon collection.

(c) Constituents grouped together are analyzed by the same method.

(d) Detection limit units except where indicated.

(e) Reference: EPA. 1982. Test Methods for Evaluating Solid Waste. SW-846, 2nd edition, Environmental Protection Agency, Washington, D.C.

(f) In-house analytical method from UST Procedure Manual UST-RT-PM-9-80 (UST 1986); based on EPA-600H-84-017 (March 1984).

(g) IC, ion chromatography.

(h) Reference: ASTM. 1986. Annual Book of ASTM Standards. Vol. 01.01, American Society of Testing Materials, Philadelphia, Pennsylvania. 
IABLE 0.2. Preservation Techniques, Analytical Methods Used, and the Current Detection Levels for the Listed Constituents (enhanced) (a) Constituent
Collection and
Preservation $(b, c, d)$

\section{ICP METALS, ENHANCED ADDITIONS}

Beryllium

Osmium

Strontium

Antimony

Thallium

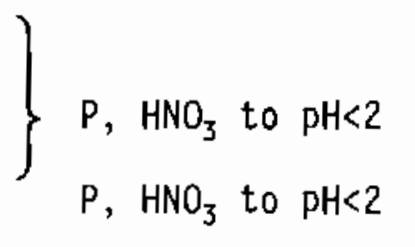

THIOUREA GROUP, ENHANCED ADDITIONS

Thiourea

1-Acety1-2-thiourea

1-(o-Ch? orophenyl) thiourea

Diethylstilbestrol

1-Naphthyl-2-thiourea

$\mathrm{N}$-Phenylthiourea

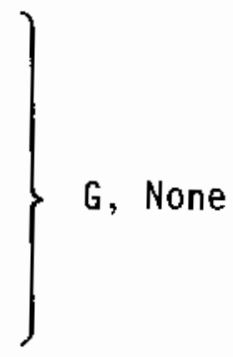

Ethylenethiourea

PESTICIOES, ENHANCED ADDITIONS

$4,4^{\prime}-000$

$4,4^{\prime}-\mathrm{DDE}$

4, $4^{\prime}$-DDT

Heptachlor

Heptachlor epoxide

Dieldrin

Aldrin

Chlordane

Endosulfan I

Endosulfan II

Chlorobenzilate
Detection

Methods

\section{HERBICIDES, ENHANCED ADDITIONS}

$2,4,5-T$

Cyanide

Perchiorate
$G$, None

$\mathrm{P}, \mathrm{NaOH}$ to $\mathrm{pH}>12$

$P$, None
$\mathrm{SH}-846(\mathrm{f}), \# 6010$

SH-B46, $\# 7840$
5

300

20

100

5

\section{PHOSPHOROUS PESTICIDES}

Carbophenothion

Tetraethylpyrophosphate

Disulfoton

Dimethoate

$G$, None

SW-846, $\$ 8330$

(modified)

200

200

200

200

200

200

500

Methyl parathion

Parathion

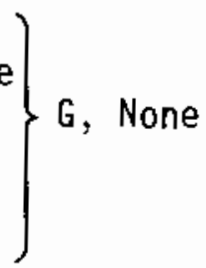

SW-846, \#8150

2

SH-846, \#9010

10

70 - IC (g)

1000

0.1

0.1

0.1

0.1

0.1

0.1

0.1

1

0.1

0.1

300 
IABLE D.2. (contd)

\begin{tabular}{|c|c|c|c|}
\hline Constituent & $\begin{array}{c}\text { Collection and } \\
\text { Preservation }(b, c, d) \\
\end{array}$ & Methods & $\begin{array}{r}\text { Detection } \\
\text { Limit. ppb (e) } \\
\end{array}$ \\
\hline $\begin{array}{l}\text { Strontium-90 } \\
\text { Gamma scan } \\
\text { Citrus red } \# 2\end{array}$ & $\begin{array}{l}\mathrm{P}, \mathrm{HNO}_{3} \text { to } \mathrm{pH}<2 \\
\mathrm{P}, \mathrm{HNO}_{3} \text { to } \mathrm{pH}<2 \\
\mathrm{G} \text {, None }\end{array}$ & $\begin{array}{l}\text { UST, } 20-S r-02(h) \\
\text { UST, } 30-G S(1)^{-6} \\
\text { AOAC } \# 34.015 B\end{array}$ & $\begin{array}{rl}5 & \mathrm{pCi} i / \mathrm{L} \\
20 \mathrm{pCi} / \mathrm{L} \\
1000\end{array}$ \\
\hline \multicolumn{4}{|c|}{ DIRECT AQUEOUS INJECTION, ENHANCED ADDITIONS } \\
\hline $\begin{array}{l}\text { Paraldehyde } \\
\text { Cyanogen bromide } \\
\text { Cyanogen chloride } \\
\text { Acrylamide } \\
\text { Allyl a]cohol } \\
\text { Chloral } \\
\text { Chloroacetaldehyde } \\
\text { 3-Chloropropionitrile } \\
\text { Cyanogen } \\
\text { Dichloropropanol } \\
\text { Ethyl carbamate } \\
\text { Ethyl cyanide } \\
\text { Ethylene oxide } \\
\text { Fluoroacetic acid } \\
\text { Glycidylaldehyde } \\
\text { Isobutyl alcohol } \\
\text { Methyl hydrazine } \\
\text { n-Propylamine } \\
\text { 2-Propyn-1-ol } \\
\text { 1, l-Dimethy] hydrazine } \\
\text { 1,2-Dimethyl hydrazine } \\
\text { Acetonitrile } \\
\text { Hydrazine }\end{array}$ & $G$, None & $S W-846 \# 8240 \mathrm{DAI}(j)$ & $\begin{array}{r}2000 \\
3000 \\
3000 \\
10000 \\
2500 \\
3000 \\
16000 \\
4000 \\
3000 \\
3000 \\
5000 \\
2000 \\
3000 \\
3000 \\
3000 \\
1000 \\
3000 \\
10000 \\
8000 \\
3000 \\
3000 \\
3000 \\
3000\end{array}$ \\
\hline $\begin{array}{l}\text { Hydrazine, LDL } \\
\text { (optiona1) }\end{array}$ & $G$, None & ASTM DI385 & 30 \\
\hline
\end{tabular}

YOAS, ENHANCED ADDITIONS

Tetrachloromethane

Methylethyl ketone

1,1,1-Trich1oroethane

1,1,2-Trichloroethane

1,1,2-Trichloroethene

Tetrachloroethene

Xylene $(0, P)$

$G$, None
No headspace

SW-846, $\# 8240$

5
10
5
5
5
5
5
10
5
10


TABLE D.2. (contd)

\begin{tabular}{c} 
Collection \\
Preservation $(B, c, d)$ \\
\hline
\end{tabular}

Constituent

Methods

Detection

Limit, ppb $(e)$

\section{A/B/N, ENHAHCED ADDITIONS}

Hexachlorophene

Naphthalene

Kerosene

Hexachlorobenzene

Pentachlorobenzene

1,2-Dichlorobenzene

1,3-Dichlorobenzene

1,4-Dichlorobenzene

1,2,3-Trichlorobenzene

1,2,4-Trichlorobenzene

1,3,5-Trich7orobenzene

$1,2,3,4$-Tetrachlorobenzene

$1,2,3,5$-Tetrachlorobenzene

1,2, 4,5-Tetrachlorobenzene

Additional semivolatiles

10
10
10000
10
10
10
10 None $\quad$ \$8270
10
10
10
10
10
10
10
10
10

\footnotetext{
(a) The parameters and constituents in this table, together with Table 0.1, compose the "long list."

(b) P, Plastic; G, Glass.

(c) All samples will be cooled to $4^{\circ} \mathrm{C}$ upon collection.

(d) Constituents grouped together are analyzed by the same method.

(e) Detection limit units except where indicated.

(f) Reference: EPA. 1982. Test Methods for Evaluating Solid Waste. SW-846, 2nd edition, Environmental Protection Agency, Washington, D.C.

(g) IC, ion chromatography.

(h) Reference: Prescribed Procedures for Measurement of Radioactivity in Drinking Water, EPA-600/4-80-32 (August 1980); Manual of Standard Procedures, Health and Safety Laboratory, United States Atomic Energy Commission, New York, 1976.

(i) A Handbook of Radioactivity Measurements and Procedures. NCRP Report 58, Washington, D.C.

(j) DAI, direct aqueous injection.
} 


\subsection{QUALITY ASSURANCE/QUALITY CONTROL}

Quality Assurance

Quality assurance (QA) will be conducted in accordance with accepted PNL QA procedures. A Site-specific QA plan describing the manner in which specific QA requirements are to be met shall be prepared in accordance with accepted QA procedures before work proceeds past the planning stages. Quality Control

Quality control (QC) will be conducted in accordance with PNL's quality control procedures. The purpose of this effort is to determine and document the quality of the analytical results being produced by the laboratory and to institute corrective actions as needed. The QC effort has two main components: 1) routine internal checks performed by UST, and 2) external checks conducted by PNL to independently evaluate UST performance. The scope of these efforts is described in the following sections.

UST Internal Quality Control

Internal quality control at UST includes general practices applicable to a wide range of analyses, as well as specific procedures stipulated for particular analyses. The quality control and quality assurance programs at UST are documented in the PNL Quality Control Manual and the Quality Assurance Manual. UST produces a quarterly Quality Control Report of Hazardous Substance Analyses to PNL for review by subcontracts, sample analyses managenent, quality control, and statistical task leaders of the ground-water monitoring program. UST External Quality Control

PNL will use both interlaboratory comparisons and spiked, replicate, and blank samples in evaluating the accuracy of results from UST. The purpose and scope of each of these is as follows.

Interlaboratory comparisons using field samples are conducted to determine if the results obtained by the primary laboratory, UST, are comparable to those obtained from other Taboratories. Comparisons are currently being conducted for anions, volatile organics, and metals. Each month, replicate samples from selected wells are delivered to four different PNL laboratories. 
The results from these PNL laboratories are then compared with the results from UST.

Spiked samples are submitted to UST to estimate the bias of analytical laboratory procedures and to determine when this bias exceeds control limits. Two types of spiked samples are being used: 1) blind, spiked samples prepared by PNL, and 2) spiked samples prepared under an established multilaboratory comparison program. Blind, spiked samples containing metals, anions, herbicides, pesticides, and volatile organic compounds (e.g., halomethanes) have been submitted quarterly since January 1986. These samples were prepared by PNL with materials supplied by Environmental Resource Associates. Additional spiked samples prepared with materials supplied by the EPA were added in June 1986. The constituents included are ammonium ion, cyanide, acid/base/neutral (ABN) compounds, and an expanded number of pesticides and volatile organic compounds. The performance of various analyses, including analyses for semivolatile organics, thiourea, phosphoric pesticides, ethylene glycol, sulfide, and perchlorate, will be monitored. UST has also received and analyzed spiked samples submitted under the EPA-sponsored Water Pollution Laboratory Performance Evaluation Study (WP016) and the Water Supply Laboratory Perforinance Evaluation Study (WSO18).

Replicate analyses of field samples will be conducted to establish how much variability might be expected in the laboratory measurements performed on nearly identical samples. Trip blanks will be submitted to UST to determine whether environmental conditions encountered during collection and transportation of samples have affected the results obtained by analysis. One trip blank is submitted each sample period per area at the rate of one for 1 to 20 wells. The trip blank is analyzed for volatile organics. 


\subsection{REFERENCES}

McGhan, V. L., P. J. Mitchell and R. S. Argo. 1985. Hanford Wells.

PNL-5397, Pacific Northwest Laboratory, Richland, Washington.

EPA. 1982. Test Methods for Evaluating Solid Waste. SW-846, 2nd edition, Environmental Protection Agency, Office of Solid Waste and Emergency Response, Washington, D.C.

UST (United States Testing Company). 1986. Procedures Manual. UST-RD-PM-9-80, Rev. 3, United States Testing Company, Inc., Rich1and, Washington. 
APPENDIX E

QUALITY ASSURANCE PLAN 
PNL-MA-70 Quality Assurance Plan No. OHE-1L, Rev. O

QA Plan for the 2101-M Pond Ground-Water Monitoring Project

Issue Date: $5 / 20 / 88$

M.A. Chamness

MA. Chauness

Cognizant Manager (Concurrence)

$5 / 19 / 88$

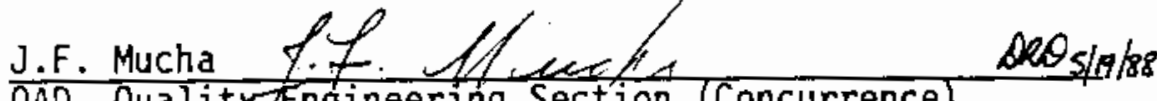

QAD, Qualityltengineering Section (Concurrence)

Date

R.M. Smith fon. Amize

E \& ESC, Site Characterization and Assessment Section (07D34) Manager (Approval)

$\frac{5 / 19 / 88}{\text { Date }}$

$\frac{5-20-86}{\text { Date }}$

E.1 

Page 2 of 4

QA PIan OHE-1L Rev. 0

\section{Project Impact Level II}

\section{$\underline{\text { Title }}$}

Quality Assurance Plan for the 2101-M Pond RCRA Ground-Water Monitoring Project.

\section{Scope}

This Quality Assurance (QA) plan along with QA Plan OHE-1, applies to the 2101-M pond ground-water monitoring project activities. A ground-water monitoring plan is being implemented under the guidelines set forth in the Resource Conservation and Recovery Act (RCRA), 40 CFR 265 subpart F, to determine the impact the 2101-M pond has on the ground-water. This plan calis for the installation, with subsequent sampling, testing and documentation of four monitoring wells.

\section{Client}

U.S. Department of Energy, Richland Operations Office (DOE-RL)-owner Westinghouse Hanford Company (WHC)-operator

\section{Authorizing Document}

13730

\section{QA Requirements Specification(s)}

$[\mathrm{X}]$ ANSI/ASME NQA-1 as delineated in PNL-MA-70
[] Other

In addition to the requirements identified in QA PIan OHE-1, Impact Leve I I activities shall comply with the requirements in Parts 1 and 3 of PNL-MA-70 as identified herein, as appropriate for the work being performed. Any identified as Impact Level III shall comply with the PNL Good Practices Standard, Part 2 of PNL-MA-70. If other quality-related activities are later performed, the appropriate PNL-MA-70 requirements and procedures shal1 be applied to them irrespective of whether they appear in the common QA plan OHE-I, or in this QA plan, unless specifically excluded. 
PNL-MA-70 Quality Assurance PTan

Page 3 of 4

QA PIan OHE-1L Rev. 0

Applicable PNL-MA-70 administrative and software control procedures along with any exclusions or limitations to the procedures are identified in Attachment 1.

Applicable technical procedures are identified in Attachment 2

Other Applicable QA Plans:

OHE-1 Rev. 0 QA Plan for the Hanford Site Environmental Monitoring Program Issue Date 7-31-87

\section{Concurrences and Approval}

Concurrences and approval of this Quality Assurance (QA) Plan are Tisted on the title page.

\section{Orqanization}

The project organization with key personnel identified is located in Attachment 3. Organizational interfaces are identified in Attachment 4.

\section{Impact Leve]}

An impact level of II has been assigned to this QA Plan because of activities where documentation of how the analytical resuits are generated is part of the deliverable and establishes the acceptability of analytical results. This documentation falls under Impact Leve] II criteria 5.d. Exceptions are noted for activities at Impact Level III in Attachment 5, WBS Impact Leve] Matrix.

\section{Special CTient Requirements}

No special client requirements have been identified.

\section{Other Reguirements, Direction or Planning}

\section{a. Preparation, Review, and Approval of Purchase Reguisitions}

Each item identifjed on a purchase requisition (PR) must have its impact level assessed and documented on the PR. If all items on a PR are assigned Impact Level III and no QA requirements apply, quality engineer (QE) review and concurrence is not required.

As a minimum, all PRs shall show evidence of technical review by signature/date of reviewer in the "Technical questions contact" block of the PR prior to submittal for Level III (or above) Manager approval, and Finance and $Q E$ concurrence (if appropriate). 
PNL-MA-70 Quality Assurance Plan

\section{Page 4 of 4}

QA PJan OHE-IL Rev O

b. Major Known Procurements

Primary analytical services to be provided by U.S. Testing, Inc, are governed by subcontract B-B2472-A-I.

c. Activities Requiring Certified Inspection Personnel

None.

d. Known Controlled Processes

Controlled processes performed by project personnel include environmenta] media sampling. Technical procedures governing these activities are identified in Attachment 2.

Controlled processes performed by others include laboratory analyses. Procedures for laboratory analys is used by U.S. Testing are documented in UST-RD-PM-9-80.

Qualification of the noted controlied processes shall not be required because they are based on standard, well-understood methods.

e. Known Special Processes

None.

f. Disposition of Records

Upon issuance of this QA P1an, records sha11 be indexed and subsequently maintained in accordance with PAP-70-1701. Records wil] not be turned over to the cilient unless specifically requested. 
QA Plan No. OHE-1L Rev 0 Attachment 1

Page 1 of 1

\section{Applicable Administrative and Software Control Procedures}

In addition to those identified in the common QA PTan OHE-1, the following administrative procedures apply to the RCRA ground-water monitoring projects. Project participants should remember to always review the common pian when determining applicable administrative procedures because the majority are identified there. For those procedures identified in OHE-1, and again below, specific exclusions or limitations have been called out in this QA Plan which do not appear in the common QA plan, OHE-1.

Pacific Northwest Laboratory Administrative Procedures (PAPs) are located in Volume I of PNL-MA-70. Software Control Procedures (SCPS may be found in volume II of PNL-MA-70

[X] PAP-70-401 PREPARATION, REVIEW, AND APPROVAL OF PURCHASE REQUISITIONS

[X] PAP-70-801 MATERIAL IDENTIFICATION AND CONTROL (TESTING AND EXPERIMENTATION) +*

[X] PAP-70-1101 TEST/ANALYSIS PLANNING, PERFORMANCE AND EVALUATION

+ See exclusions or limitations of applicability below for clarification.

* Applies to identification of environmental media samples.

\section{EXCLUSIONS OR LIMITATIONS OF APPLICABILITY}

The following exclusions or limitations of applicability apply to the procedures identified above.

a. PAP-70-801: Material Identification and Control

Inventory control, identified in Sections 4.2 .1 and 4.2 .2 of PAP-70-801 shall not be required for environmental media samples. Also, the Chainof-Custody Form may be used in Tieu of the Material Identification Card identified in PAP-70-801. Field sampling, transportation and Chain-ofCustody procedures are in PNL-MA -580 . 
QA Plan No. OHE-1L Rev 0 Attachment 2

Page 1 of 1

\section{Applicable Technical Procedures}

Number \& Rev.

PNL-MA-580

$P-1$

P.2

P-3

$P-5^{*}$

$P-6$

P-7
Title or Subject

Environmental Monitoring Procedures

Sample Disposal

Data Handing and Verification

Statistical Analysis

Procedure for Water Level

Measurements for the 100 H Area Water Level Monitoring Network for RCRA, Hazardous Materials Monitoring

Procedure for collection and Documentation of Drilling Data for RCRA Compliance/Hazardous Materials Monitoring

$$
\begin{array}{lr}
\text { Quality Control Procedures for } & 7 / 23 / 87 \\
\text { Collection of Samples for RCRA, } & \\
\text { CERCLA, SARA and other Compliance/ } & \\
\text { Hazardous Materials Monitoring } & \\
\text { Hydrostar Pump Well Sampling } & 8 / 19 / 87 \\
\text { Procedure } & \\
\text { In-Line Filtration Procedure } & 8 / 19 / 87
\end{array}
$$

Issue Date (actual or planned)

$9 / 86$

$11 / 24 / 86$

$3 / 30 / 87$

$11 / 24 / 86$

$1 / 5 / 87$

$7 / 23 / 87$

* Procedure P-5 was originally developed for use by the 183H RCRA Compliance Ground-Water Monitoring Project. All ground-water monitoring projects are utilizing procedure P-5 for water-leveî measurements. 
QA PIan OHE-1L, Rev. 0 Attachment 3

Page 1 of 1

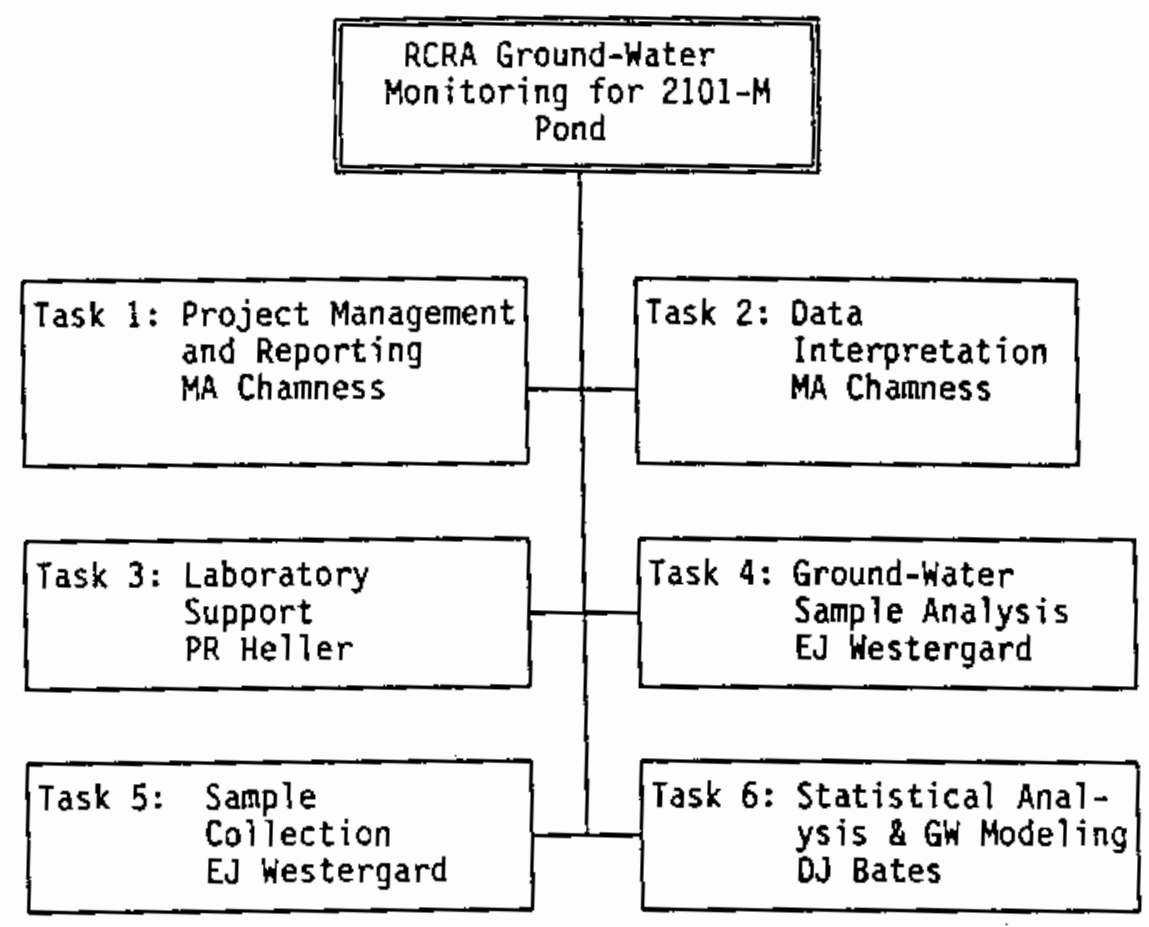

PROJECT ORGANIZATION

E.8 
QA Plan OHE-1L, Rey. 0

Attachment 4

Page 1 of 1
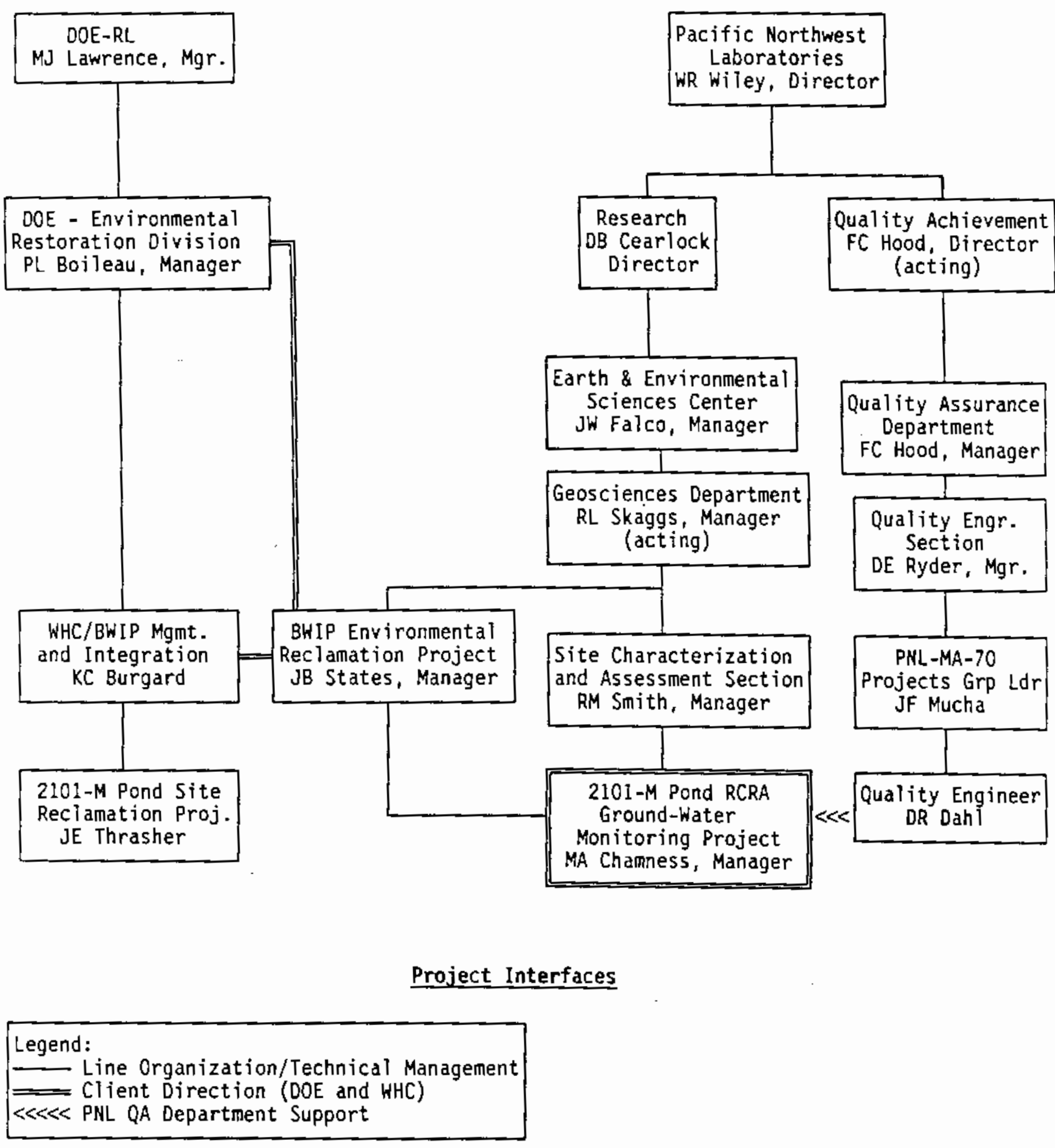


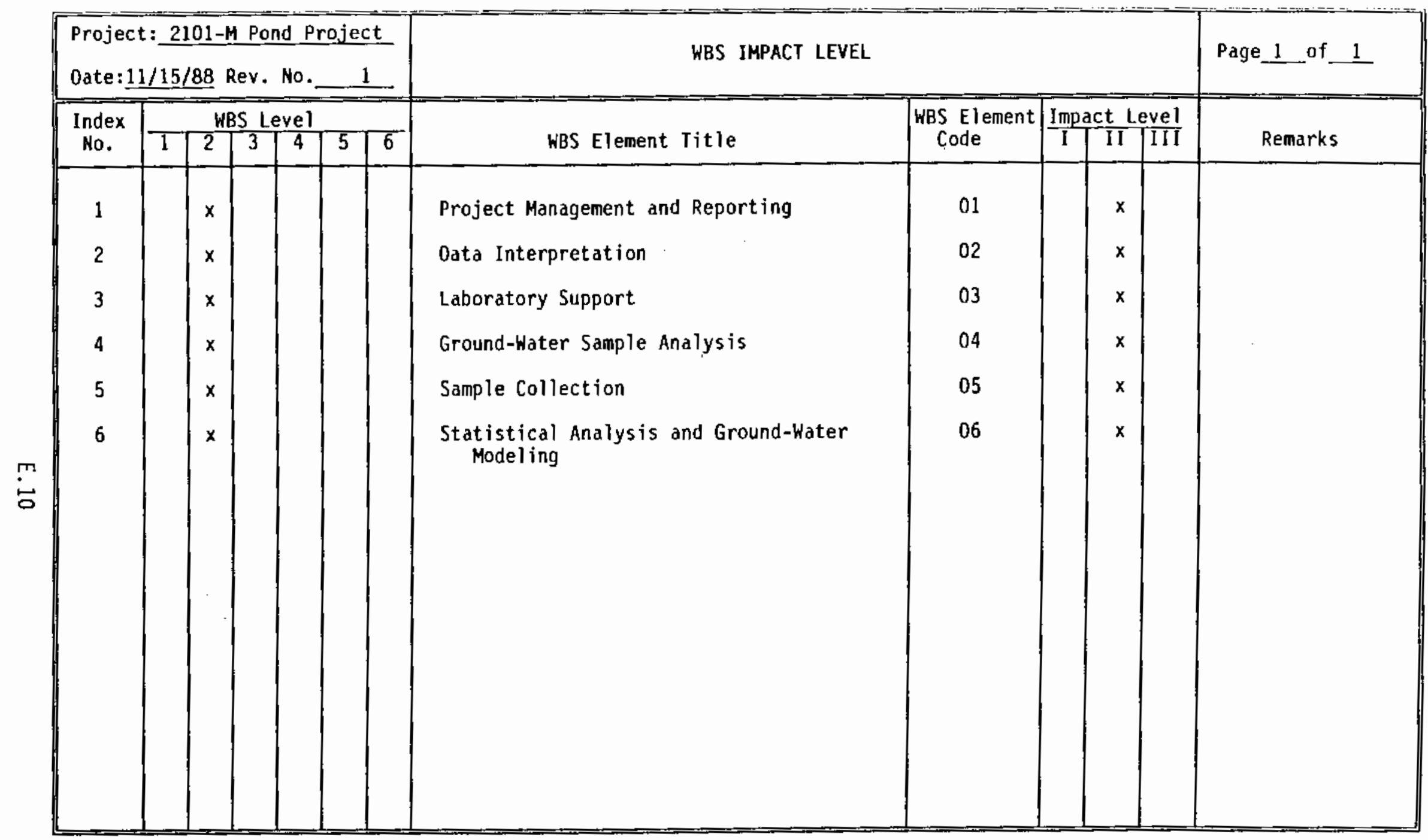


PNL -6851

UC $-11,41$

\section{DISTRIBUTION}

No. of

Copies

OFFSITE

10 DOE/Office of Scientific and Technical Information

\section{ONSITE}

2 DOE Richland Operations office

P. L. Boileau, A5-10

P. H. Turner, A5-10

11 Westinghouse Hanford Company

K. C. Bugard, H9-2I

J. A. Caggiano, H4-55

K. R. Fecht, H4-56

C. J. Geier, H4-57

N. M. Hutchins, H9-21

R. L. Jackson, H4-56

D. E. Mahagin, H9-2l

F. V. Roeck, H4-55

J. S. Schmid, H4-57

J. E. Thrasher, H9-2l

J. G. Woolard, H4-57
No. of

Copies

20 Pacific Northwest Laboratory

C. A. Brandt, K5-11

M. A. Chamness, K6-96

J. W. Falco, $\mathrm{K} 6-78$

J. M. Hales, K6-04

P. C. Hays, K6-86

G. V. Last, K6-96

R. E. Lundgren, K6-86

S. P. Luttre 11, K6-96

P. J. Mitche11, K6-97

T. L. Page, K5-16

R. L. Skaggs, $\mathrm{K} 6-77$

J. B. States, K5-11

J. A. Stottlemyre, K6-94

R. E. Wildung, P7-50

Publishing Coordination

Technical Report Files (5) 


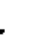

